\title{
Fatty acid-binding protein in rat heart
}

Citation for published version (APA):

Vork, M. M. (1993). Fatty acid-binding protein in rat heart. [Doctoral Thesis, Maastricht University]. Datawyse / Universitaire Pers Maastricht. https://doi.org/10.26481/dis.19930429mv

Document status and date:

Published: 01/01/1993

DOI:

10.26481/dis. $19930429 \mathrm{mv}$

Document Version:

Publisher's PDF, also known as Version of record

\section{Please check the document version of this publication:}

- A submitted manuscript is the version of the article upon submission and before peer-review. There can be important differences between the submitted version and the official published version of record.

People interested in the research are advised to contact the author for the final version of the publication, or visit the DOI to the publisher's website.

- The final author version and the galley proof are versions of the publication after peer review.

- The final published version features the final layout of the paper including the volume, issue and page numbers.

Link to publication

\footnotetext{
General rights rights.

- You may freely distribute the URL identifying the publication in the public portal. please follow below link for the End User Agreement:

www.umlib.nl/taverne-license

Take down policy

If you believe that this document breaches copyright please contact us at:

repository@maastrichtuniversity.nl

providing details and we will investigate your claim.
}

Copyright and moral rights for the publications made accessible in the public portal are retained by the authors and/or other copyright owners and it is a condition of accessing publications that users recognise and abide by the legal requirements associated with these

- Users may download and print one copy of any publication from the public portal for the purpose of private study or research.

- You may not further distribute the material or use it for any profit-making activity or commercial gain

If the publication is distributed under the terms of Article $25 \mathrm{fa}$ of the Dutch Copyright Act, indicated by the "Taverne" license above, 
FATTY ACID-BINDING PROTEIN IN RAT HEART 


\section{FATTY ACID-BINDING PROTEIN IN RAT HEART}

\section{PROEFSCHRIFT}

ter verkrijging van de graad van doctor

aan de Rijksuniversiteit Limburg te Maastricht,

op gezag van de Rector Magnificus, Prof. Mr. M.J. Cohen,

volgens het besluit van het College van Dekanen,

in het openbaar te verdedigen op donderdag 29 april 1993 om 14.00 uur

door

Michaël Maria Vork

geboren te Roermond in 1961

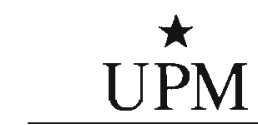

UNIVERSITAIRE PERS MAASTRICHT 
Promotor : Prof. Dr. G.J. van der Vusse

Co-promotor : Dr. J.F.C. Glatz

Beoordelingscommissie:

Prof. Dr. J.F.M. Smits, voorzitter

Prof. Dr. M. Borgers

Prof. Dr. A. van der Laarse (Academisch ziekenhuis Leiden)

Prof. Dr. F. Spener (Universiteit van Münster, Duitsland)

Prof. Dr. R.F.A. Zwaal

CIP-GEGEVENS KONINKLIJKE BIBLIOTHEEK, DEN HAAG

Vork, Michaël Maria

Fatty acid-binding protein in rat heart / Michaël Maria

Vork. - Maastricht : Universitaire Pers Maastricht. - III.

Proefschrift Maastricht. - Met lit. opg. - Met

samenvatting in het Nederlands.

ISBN 90-5278-071-4

NUGI 743

Trefw.: velzuur-bindende eiwitten / cardiaal vetzuur

metabolisme.

Financial support by the Netherlands Heart Foundation for the publication of this thesis is gratefully acknowledged.

De totstandkoming van dit proefschrift is mede mogelijk gemaakt door financiële steun van de Stichting Wetenschappelijk Durrer Fonds

Tot op heden zịn financiële bijdragen ontvangen van de volgende bedrijven:

Varian Nederland B.V.

Bio-Rad Laboratories B.V. 
Aan en voor allen die op welke wijze dan ook hebben bijgedragen aan de totstandkoming van dit boekje, maar vooral voor Brigitte die al die tijd heeft gedacht dat ik mijn tijd vulde met het spoelen van buisjes. 


\section{.}




\section{CONTENTS}

$\begin{array}{ll}\text { CHAPTER 1: Introduction } & 7\end{array}$

CHAPTER 2: Lipid solubilizing and transporting systems in mammals 13

CHAPTER 3: Assay of the binding of fatty acids by proteins: evaluation of the Lipidex 1000 procedure

CHAPTER 4: A sandwich enzyme linked immuno-sorbent assay for the determination of rat heart fatty acid-binding protein

CHAPTER 5: Heterogeneous distribution of fatty acid-binding protein in hearts of Wistar-Kyoto and spontaneously hypertensive rats

CHAPTER 6: On the mechanism of long chain fatty acid transport in cardiomyocytes as facilitated by cytoplasmic fatty acid-binding protein

CHAPTER 7: Protein release from isolated rat heart during normoxia, low-flow ischemia and reperfusion

CHAPTER 8: Release of fatty acid-binding protein and long chain fatty acids from isolated rat heart after ischemia and subsequent calcium paradox

CHAPTER 9: General discussion

Summary

Samenvatting

List of publications

Curriculum vitae 
CHAPTER 1

INTRODUCTION 


\section{Cardiac function}

The heart serves as a pump to supply all tissues with blood in order to deliver nutrients and molecular oxygen. During the average life expectance time of a human being in the western world 200 million litres of blood are pumped through the body in approximately 2.5 billion beats. To achieve this extraordinary performance, the heart itself also needs a continuous supply of oxygen and nutrients, including carbohydrates and fatty acids. Therefore, already during rest about $4 \%(225 \mathrm{ml} / \mathrm{min})$ of the total blood volume pumped out by the heart is directly delivered to its own vascular system (coronary circulation) resulting in a cardiac oxygen uptake of about $10 \%$ of the total body uptake. Upon heavy exercise the coronary flow can increase three to four fold, in order to ensure sufficient supply of substrates (Guyton, 1991).

\section{Cardiac fatty acid metabolism}

Under normal rest conditions the preferred substrates of the heart are long chain fatty acids (FA) ', although lactate is also readily taken up and oxidized by the heart when present in the blood (Opie, 1991). A major part of FA taken up by the heart, i.e. 50-100 $\mathrm{nmol} / \mathrm{min}$ per gram tissue under normal conditions (Van der Vusse et al, 1992), is immediately oxidized for the generation of energy necessary for proper function and maintenance of cellular integrity. Another part of the absorbed fatty acids is used for the formation of phospholipids, important constituents of the cellular membranes, and other complex lipid compounds (Van der Vusse et al, 1992). The cardiac FA uptake largely depends on the arterial FA concentration and the concentration of other potential substrates, such as lactate and glucose (Opie, 1991). Although FA are taken up by the heart in appreciable quantities the FA concentration in cardiac tissue is remarkably low, i.e. 12 to 23 nmol per gram tissue for rat and dog heart tissue, respectively (Van der Vusse, 1982; De Groot, 1989) which indicates an efficient intra-myocardial FA processing. During prolonged ischemia, i.e. deprivation of oxygen and nutrients, and subsequent restoration of the cardiac circulation (reperfusion) the FA concentration is known to rise in cardiac tissue (Weglicki et al, 1973; Chien et al, 1984; Van Bilsen et al, 1989), indicating a disturbance in normal cardiac FA homeostasis. In this respect it is noteworthy that high levels of FA may have detrimental effects on the function and integrity of the heart (Van der Vusse et al, 1992).

\section{Cardlac fatty acid transport}

FA that are taken up by the heart have to cross a number of barriers (Figure 1.1). A complicating factor in the transport of FA is the fact that these substances possess a low aqueous solubility, thus will most likely require carrier systems for efficient transport. Although overall cardiac FA uptake and utilization is easily measurable, e.g. from the production of ${ }^{14} \mathrm{CO}_{2}$ from ${ }^{14} \mathrm{C}$-labeled $\mathrm{FA}_{\text {, }}$ only limited information of the separate mechanisms by which FA cross the barriers shown in Figure 1.1. is available. An overview of possible mechanisms has been described by Bassingthwaighte and co-workers (1989).

\footnotetext{
${ }^{1}$ Throughout the thesis the nomenclature for fatty acids, as outlined by Glatz and Van der Vusse (1988) will be used.
} 


\section{Role of fatty acid-binding protein in the myocardium}

In the present study attention is focused on the significance of a relatively small protein (15 kDa), found in the cytoplasm of the cardiomyocyte and which can bind FA in vitro (Mishkin et al, 1972; Ockner et al, 1972). Although this fatty acid-binding protein (FABP) has been studied for more than 20 years, definite proof regarding its physiological function(s) is still lacking. Since it is very likely that FA binding also occurs in vivo, the heart type fatty acid-binding protein ${ }^{2}$ is thought to play an important role in the cardiac lipid homeostasis. Several research groups have postulated biological functions for FABP, such as ( $I$ ) an intracellular carrier for fatty acids (Ockner et al, 1972), (ii) the binding of excess tissue FA, e.g. during ischemia and subsequent reperfusion of the heart, thereby preventing harmful effects of elevated FA levels (Brecher, 1983; Glatz et al, 1985), and (iii) the control of cardiac energy production (Fournier and Rahim, 1985).

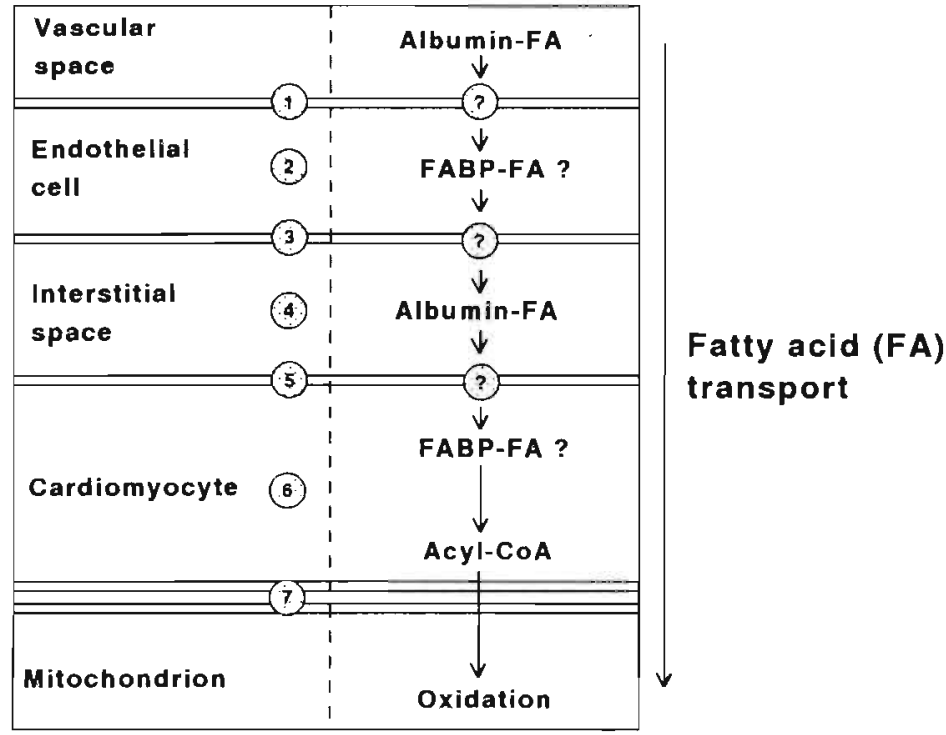

Fig. 1.1. Barriers encountered by FA during transport from vasculature to mitochondrion: (1) endothelial luminal membrane, (2) endothelial cytoplasm, (3) basolateral membrane of the endothelial cell, (4) interstitial space, (5) cardiomyocytal membrane (sarcolemma), (6) cytoplasm of the cardiomyocyte, (7) mitochondrial membranes.

\section{FABP and injured myocardium.}

Upon injury of cardiac tissue, intracellular proteins and other compounds are released from the cells and can be detected in blood plasma (LaDue et al, 1954). Measuring these cell-borne proteins in the blood has become a powerful tool in clinical chemistry for the diagnosis of tissue damage in a variety of organs (Demetriou et al, 1974). At present, mostly

${ }^{2}$ Throughout the thesis the term FABP refers to cytoplasmic H(eart-type)- FABP, unless explicitly indicated otherwise. 
the activities of intracellular enzymes are measured in plasma to monitor cardiac damage, e.g. lactate dehydrogenase (LDH), creatine kinase iso-enzyme $\mathrm{MB}$ (CK-MB) and aspartate amino transferase (AST), since enzyme assays are sensitive and often easy to perform. Moreover, the normal plasma concentrations of intracellular enzymes are usually low. It has been shown by Glatz and colleagues (1988) that, besides enzymes, FABP is also released from ischemically damaged isolated rat hearts. The above mentioned enzymes all have a fairly high molecular mass when compared to FABP. It might be possible that due to this difference in molecular mass the release of enzymes from tissue is delayed, relative to that of FABP. If this is true, determination of FABP release from injured myocardium might be useful for the early detection of myocardial infarction. Moreover, FABP release from the myocardium might indicate an increased cardiac vulnerability for enhanced levels of FA since it would decrease the putative FA buffering capacity of FABP.

\section{Aim and outline of the study}

To gain insight into the mechanisms of lipid transport in an aqueous environment and the various lipid transporting systems in mammals, a literature review on this subject is presented in Chapter 2, with special focus on the present knowledge and suggested role of cardiac FABP. To date a variety of data is available on various aspects of FABP, such as FA binding affinity and stoichiometry, and tissue content. However, large differences in these parameter values have been reported. Therefore, the first aim of the present study was to develop methods to accurately and reproducibly determine these parameters (Chapter 3 and 4). In a subsequent study the intra-myocardial distribution of FABP was investigated in normal rats and in hypertensive rats to gain insight into the possible relationship between FABP content and cardiac workload (Chapter 5).

Since the putative FA transporting function of FABP has still not been established, an attempt was made to describe the cardiac intracellular FA transport in a mathematical model (Chapter 6).

In two studies using isolated perfused rat hearts information was gained on questions of (I) tissue protein release during ischemia and reperfusion and the relationship between this release and physico-chemical properties of the protein (Chapter 7), and (ii) the capability of FABP to bind FA in vivo (Chapter 8 ). Finally, the results of the studies are discussed and summarized in Chapter 9 and some suggestions for future research are given.

\section{REFERENCES}

Bassingthwalghte JB, Noodleman L, Van der Vusse GJ, Glatz JFC. 1989. Modeling of paimitate transport in the heart. Mol Cell Biochem 88, 51-58.

Brecher P. 1983. The interaction of long-chain acyl CoA with membranes. Mol Cell Biochem 57, 3-15.

Chien KR, Han A, Sen A, Buja LM, Willerson JT. 1984. Accumulation of unesterified arachidonic acid in ischemic canine myocardium. Circ Res 54, 313-322.

De Groot MJM, Willemsen PHM, Coumans WA, Van Bilsen M, Van der Vusse GJ. 1989. Lactate-induced stimulation of myocardial triacylglycerol turnover. Biochim Biophys Acta 1006, 111-115.

Demetriou JA, Drewes PA, Gin JB. 1974. In: Clinical chemistry, principles and practice, chapter 21. Ed. Henry RJ, Cannon DC, Winkelman JW. Harper and Row, Publishers, Inc. Hagerstown, USA.

Fournier NC, Rahim M. 1985. Control of energy production in the heart: A new function for fatty acid-binding protein. Biochemistry 24, 2387-2396.

Glatz JFC, Paulussen RJA, Veerkamp JH. 1985. Fatty acid-binding proteins from heart. Chem Phys Lipids 38, 115-129.

Glatz JFC, Van der Vusse GJ. 1988. Lipid terminology:'free' fatty acid is ambiguous. Trends Biochem Sci 13, 167-168. 
Glatz JFC, Van Bilsen M, Paulussen RJA, Veerkamp JH, Van der Vusse GJ. 1988. Release of fatty acidbinding protein from isolated rat heart subjected to ischemia and reperfusion or to the calcium paradox. Biochim Biophys Acta 961, 148-152.

Guyton AC. 1991. Textbook of medical physiology. 8th ed. Chapter 21. W.B. Saunders Company, Philadelphia, USA.

Mishkin S, Stein L, Gatmaitan Z, Arias IM. 1972. The binding of fatty acids to cytoplasmic proteins : Binding to $Z$ protein in liver and other tissues of the rat. Biochem Biophys Res Commun 47, 997-1003.

LaDue JS, Wróblewski F, Karmen A. 1954. Serum glutamic oxaloacetic transaminase activity in human acute transmural myocardial infarction. Science 120, 497-499.

Ockner RK, Manning JA, Poppenhausen RB, Ho WKL. 1972. A binding protein for fatty acids in cytosol of intestinal mucosa, liver, myocardium, and other tissues. Science 177, 56-58.

Opie LH. 1991. The heart: Physiology and metabolism. 2nd ed. Raven Press, New York, USA.

Van Bilsen M, Van'der Vusse GJ, Willemsen PHM, Coumans WA, Roemen THM, Reneman RS. 1989. Lipid alterations in isolated, working rat hearts during ischemia and reperfusion. Circ Res 64, 304-314.

Van der Vusse GJ, Roemen THM, Prinzen FW, Coumans WA, Reneman RS. 1982. Uptake and tissue content of fatty acids in dog myocardium under normoxic and ischemic conditions. Circ Res 50, 538.546.

Van der Vusse GJ, Glatz JFC, Stam HCG, Reneman RS. 1992. Fatty acid homeostasis in the normoxic and ischemic heart. Physiol Rev 72, 881-940.

Weglicki WB, Owens K, Urschel CW, Serur JR, Sonnenblick EH. 1973. Hydrolysis of myocardial lipids during acidosis and ischemia. Rec Adv Stud Cardiac Struct Metab 3, 781-793. 
CHAPTER 2

LIPID SOLUBILIZING AND TRANSPORTING SYSTEMS IN MAMMALS 
The aim of this chapter is to give an overview of the various extra- and intracellular lipid solubilizing and transporting systems in mammals. After discussing the uptake and processing of lipids from the gastro-intestinal tract, and the lymph and blood transport of these compounds, attention will be focused on the various intracellular lipid-binding proteins, with emphasis on the fatty acid-binding protein present in the myocardium.

\section{Introduction}

Lipids are extremely important substances for the mammalian body for a number of reasons. Firstly, major amounts of energy are derived from the intracellular breakdown of fatty acids. Secondly, lipids play a crucial role in the separation of the different body compartments, i.e. extracellular versus intracellular spaces, by means of semi-permeable membrane formation. Thirdly, lipids are excellent substances for the efficient storage of energy in the form of triacylglycerols. Fourthly, many important active biological substances possess a lipid nature, such as steroid hormones, prostaglandins and other eicosanoids. Many lipid substances can be produced by the mammalian body, mainly by the conversion of carbohydrates into lipids (Stryer, 1988). Most lipids are poorly soluble in aqueous body fluids, so that their transport in the body usually requires special carrier mechanisms. Therefore, the body is equipped with a variety of systems for the efficient solubilisation and transport of lipid substances (For reviews see Jackson et al, 1977; Masoro, 1977; Shiau, 1987).

\section{Intestinal breakdown, uptake and processing of lipids.}

The lipid content of the diet mainly consists of neutral fat (triacylglycerols), accounting for approximately $40 \%$ of the total caloric intake, and to a lesser extent fatty acids (FA), phospholipids (PL), cholesterol and cholesterol-esters (Figure 2.1). In order to achieve an efficient intestinal uptake these compounds have to be in close contact with the water soluble lipid converting enzymes secreted mainly by the pancreas into the duodenal lumen (Sarda and Desnuelle, 1958). The dietary lipids have the tendency to remain in fairly large aggregates (globules) thus making them less available for enzymatic breakdown. To increase the surface of these lipid globules, bile, which is produced by the liver, is added to the contents of the duodenal lumen. Bile contains cholesterol, bile salts (compounds derived from cholesterol), and PL (mainly phosphatidylcholine or lecithin). The latter two substances have an amphipatic nature which makes them soluble in both water and lipids. By the small intestinal movement an adequate mixing of bile and dietary lipids occurs which results in an approximate 1000 fold increase in lipid surface. Subsequently an efficient breakdown of lipids can be performed by pancreatic lipase which converts triacylglycerols into FA and monoacylglycerols (Desnuelle, 1961) whereas a small part remains in the diacylglycerol state. PL are converted by pancreatic phospholipase A into lyso-phospholipids (Borgström, 1974) which are fairly soluble in the aqueous intestinal content (chyme). The products of the enzymatic conversion have to be shuttled away from the site of conversion in order to keep the breakdown process going. However, the intestinal breakdown of triacylglycerols only slightly increases the aqueous solubility of most endproducts. In order to shuttle breakdown products towards the intestinal epithelium, bile salts form 20-40 molecule aggregates. In these so-called micelles the hydrophobic parts of the salt molecules form the interior whereas the hydrophillic headgroups are located on the outside of the micelle. This makes a micelle highly soluble in water despite its fairly large size. 
FA and monoacylglycerols dissolve in the micelles thus keeping their aqueous concentration low resulting in a continuous breakdown of triacylglycerols. When a micelle comes in direct contact with the intestinal epithelium (enterocyte), FA and monoacyiglycerols are believed to dissolve in the cellular membrane after which they diffuse into the interior of the cell. Lipid resorption mainly occurs at the site of the proximal jejunum and is essentially complete (Shiau, 1987).
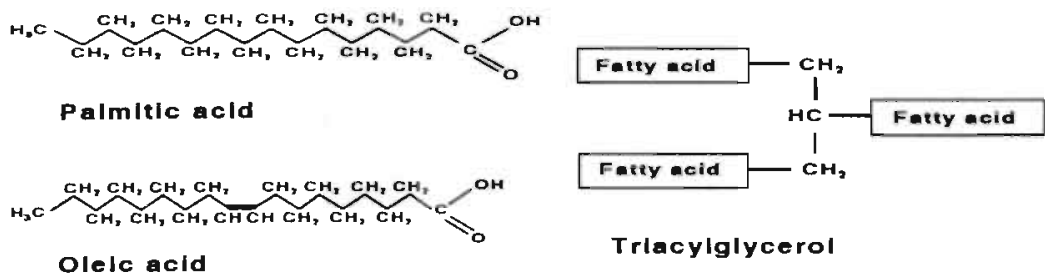

Triacylglycerol
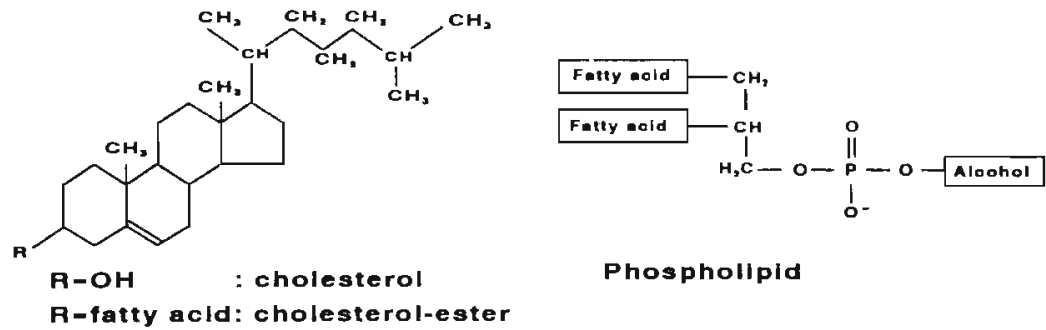

Phospholipid

Fig. 2.1. Common lipid substances in mammalian tissues

Transport of FA and monoacylglycerols from the plasmalemma to the intracellular sites of conversion may be mediated by two fatty acid-binding proteins (FABP) present inside the cytoplasm of the enterocyte, the so-called liver type (L-FABP) and the intestinal type (I-FABP) (Ockner and Manning, 1974; Bass et al, 1985; Cistola et al, 1989). Furthermore, a protein with binding affinity for bile salts and bilirubin is present in this cell-type (Walz et al, 1988).

in the smooth endoplasmic reticulum of the enterocyte essentially all monoacylglycerols, FA and lyso-phospholipids are converted back into triacylglycerols and PL, respectively (Brindley, 1974; Shiau, 1987). Thereafter chylomicrons are formed which are structures of $0.1 \mu \mathrm{m}$ in diameter or larger (Zilversmit, 1967; Mahley et al, 1971; Davies, 1991) composed of triacylglycerols, PL, cholesterol and cholesterol-esters together with a variety of apolipoproteins (Hamilton 1972; Shiau, 1987; Davies, 1991). These latter proteins, which are essential for the excretion of chylomicrons from the cell and the extracellular recognition of these particles, form an envelop around the lipid core which makes these particles soluble in an aqueous environment. After formation, chylomicrons are excreted from the enterocyte into the lymph via exocytosis of Golgi vesicles (Brindley, 1974; Davies, 1991). At this point the main constituents of chylomicrons are triacylglycerols and PL $(88 \%$ and $9 \%$, respectively), whereas the protein envelop amounts to $1 \%$ of total weight (Eisenberg and Levy, 1975). Small and medium chain fatty acids are not processed in the enterocyte but, after crossing these cells, directly enter the portal blood (Jackson, 1974). Figure 2.2. shows a schematic overview of the above described processes. 


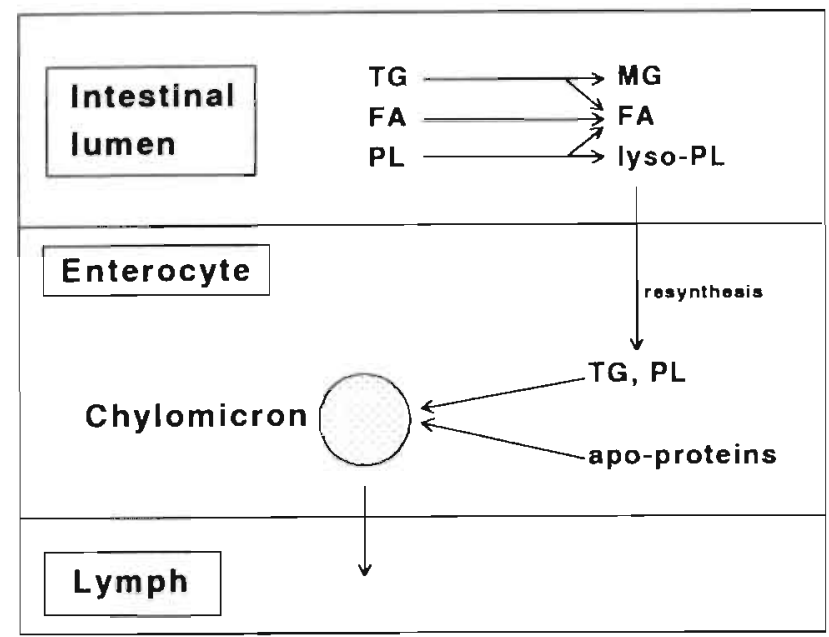

Fig. 2.2. Schematic representation of intestinal lipid breakdown, uptake and processing. TG, triacylglycerol; FA, fatty acid; PL, phospholipid; MG, monoacylglycerol; lyso-PL, lyso-phospholipid)

\section{Extracellular transport of dietary lipids}

On entering the bloodstream via the thoracic duct, exchange of apoproteins occurs between the various lipoproteins (Fielding and Fielding, 1991). Removal of FA from triacylglycerols of the chylomicrons and from very low density lipoproteins, produced by the liver, occurs in tissues containing lipoprotein lipase at the endothelial lining of the microvessels, such as skeletal muscle, heart muscle, liver and adipose tissue (Felts, 1975; Schneider, 1991, Brindley, 1991). In the heart, triacylglycerols and PL, originating from chylomicrons and very low density lipoproteins, are hydrolysed by the endothelial bound lipoprotein lipase (Cryer, 1989; Groot et al, 1979). This enzyme is synthesized in the parenchymal cell of the heart, is then secreted into the interstitial space and finally transported to the luminal side of the endothelium. After hydrolysis of triacylglycerols by lipoprotein lipase, predominantly into FA, monoacylglycerol and glycerol, these products are taken up by the target tissues after which they can immediately be metabolized (Jones and Havel, 1967; Smith and Scow, 1979), incorporated into the PL pool or stored in triacylglycerols (Kreisberg, 1966). Storage of triacylgiycerols predominantly occurs in adipose tissue (Havel, 1972). In man, the complete removal of triacylglycerols from chylomicrons occurs in less than one hour (Eisenberg and Levy, 1975). After extraction and hydrolysation of triacylglycerols from chylomicrons the remnant particle is processed by the liver (Higgins and Fielding, 1975). For reviews on lipoprotein physiology, including lipoprotein synthesis from endogenous lipid pools by the liver, see Jackson et al (1977), Bisgaier and Glickman (1983) and Vance and Vance (1991).

\section{Mobilization of stored lipids}

The above described processes occur whenever lipids enter the body via the gastrointestinal tract. A large part of the lipids that are not oxidized instantaneously after uptake 
from the bloodstream are stored in adipose tissue as triacylglycerols under the influence of high levels of insulin. Furthermore, excess carbohydrates are, after conversion into FA and subsequent incorporation in very low density lipoproteins in the liver, also stored as lipids. These energy reserves can be used whenever dietary energy supplies are not available or insufficient. Mobilization of the lipid stores from adipose tissue occurs through hormonal activation of the adipocyte lipases by glucagon and adrenalin. In this process, cyclic AMP (cAMP) acts as a mediator for the activation of a protein kinase which then activates lipase by phosphorylation (Khoo et al, 1974; Siddle and Halis, 1975). Triacylglycerols are subsequently broken down into FA and glycerol, which both are released into the blood. In the blood, FA are transported bound to albumin which contains at least six binding sites for long chain fatty acid molecules (Goodman, 1958; Spector et al, 1969; Kragh-Hansen, 1981; Peters, 1985; Rothschild et al, 1988).

The binding of FA by albumin is another example of a mechanism, besides lipoprotein formation, by which efficient bulk transport of lipid substances in the aqueous blood-plasma occurs. The true monomeric aqueous solubility of FA (e.g. palmitic acid) was measured to be less than $2 \mathrm{nM}$ (Broderson et al, 1990; Vorum et al, 1992). The presence of albumin can enhance this solubility at least 5 orders of magnitude even at a 1 to 1 binding of FA. The plasma albumin concentration amounts to $600 \mu \mathrm{M}$ whereas, at normal fed conditions, the blood plasma FA concentration amounts to 300-500 $\mu \mathrm{M}$ (Potter et al, 1989) indicating an albumin:FA ratio of $0.5-0.8$. The disappearance of FA from blood is a fast process with a half-life time of about 2 min (Spector, 1986). FA released from adipose tissue can be directly delivered to the target tissue for metabolization. Another route for FA is the re-incorporation into triacylglycerols in the liver and the subsequent release into plasma as very low density lipoproteins. Triacylglycerols in these particles can be hydrolysed by lipoprotein lipase, after which uptake of FA and monoacylglycerols takes place (Brindley, 1991) (Figure 2.3.).

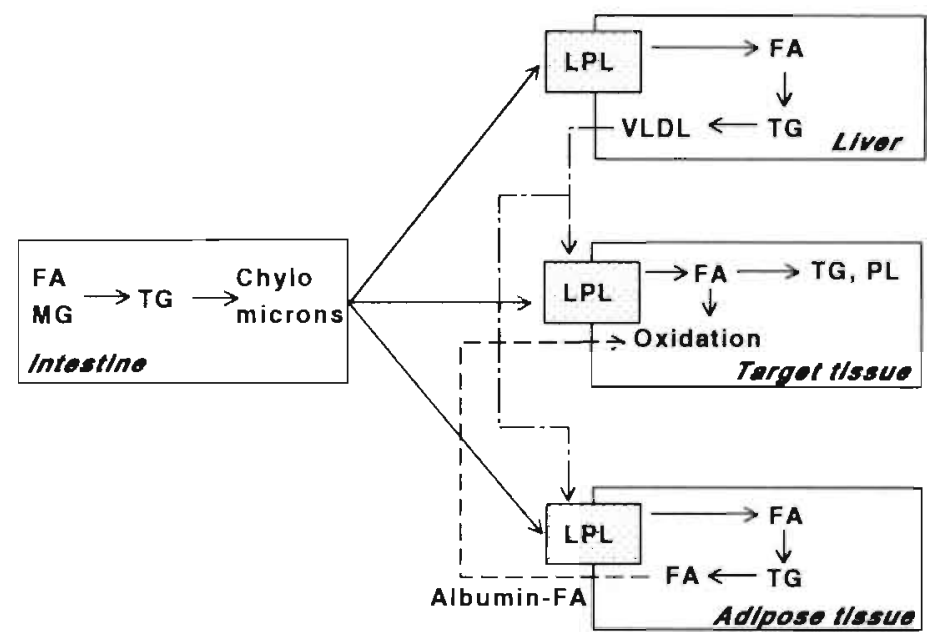

Fig. 2.3. Main pathways of bulk lipid transpon and cellular utilization in mammals. LPL, lipoprotein lipase; VLDL, very low density lipoproteins; target tissue, e.g. skeletal muscle or heart. 


\section{Intracellular lipid binding proteins}

The main differences between extracellular and intracellular lipid binding factors is that the extracellular transport usually implies transport over relatively large distances (millimetres to meters) by means of mixing (intestine) or convection (lymph and blood) whereas intracellular transport occurs within micrometer distances, most likely via diffusion. Lipid processing usually occurs at intracellular organelles, such as mitochondria and the endoplasmic reticulum, thus the aqueous cytoplasm has to be crossed. Although intracellular distances are very small, most lipid compounds probably need a carrier to increase the diffusional flux of these substances (facilitated diffusion). Each cell is surrounded by a hydrophobic barrier, the cellular membrane, in which lipids readily dissolve, whereas the aqueous solubility of most lipids is extremely low. In many tissue types of plant and animal origin proteins have been found which are able to bind and thus solubilize lipids in vitro (Spener and Mukherjea, 1990). It is justified to assume that these proteins also bind lipid structures in vivo and thus may have a function in the intracellular trafficking of lipids. However, to date no direct observations on intracellular lipid transport by these proteins have been reported. The present overview is confined to those proteins which are detected in tissue from mammalian origin (Table 2.1.). However, it should be indicated that intracellular lipid binding proteins are also found in other organisms such as plants (Kader, 1990), insects (Haunerland, 1990), and prokaryotes (Paltauf and Daum, 1990).

\section{Non-specific lipid transfer proteins (nsL-TP)}

Non-specific lipid transfer protein (nsLTP), also known as sterol carrier protein 2 $\left(\mathrm{SCP}_{2}\right)$, was first identified in rat liver cytosol (Bloj and Zilversmit, 1977), but has now been identified in the liver, intestine and ovary of various mammalian species. nSLTP has been shown to be able to bind a variety of lipid compounds in vitro, such as PL, diacylglycerols, gangliosides, glycosphingolipids and cholesterol. Moreover, it is capable of enhancing the enzymatic synthesis and modification of cholesterol in vitro (Gavey et al, 1981; Chanderbhan et al, 1984), probably by binding intermediate compounds in order to make them readily available for enzymatic conversion.

\section{Phospholipid transfer proteins (PL-TP)}

Another group of lipid binding proteins is able to bind a variety of PL. The presence of a PL transferring protein was first discovered by Wirtz and Zilversmit (1967) in cytosol preparations from rat liver. They showed that these proteins could stimulate the exchange of PL molecules between PL bilayers in vitro. During the following years several distinct PL transferring proteins were discovered and purified, such as (i) nsLTP (see above), (ii) phosphatidylcholine transferring protein (PC-TP) from bovine (Kamp et al, 1973) and rat liver (Poorthuis et al, 1980) and (iii) phosphatidylinositol transferring protein (PI-TP) from bovine heart (DiCorleto et al, 1979) and brain (Helmkamp, 1974) and human platelets (George and Helmkamp, 1985). PC-TP will only bind PC, whereas PI-TP has a high affinity for PI but also binds PC. These proteins are thought to play a role in the exchange of PL molecules between various intracellular membranes. However, no definite proof of this putative function in vivo has been provided yet (Wirtz, 1991). 
Sterol carrier proteins (SCP)

A number of intracellular sterol carrier proteins, capable of binding sterol compounds in vitro, have been identified during the last two decades (Billheimer and Reinhart, 1990). These include cholesterol binding proteins (Erickson et al, 1978; LeFevre et al, 1978; Higuchi et al, 1981; Ohta et al, 1982; Sziegoleit, 1982), sterol carrier proteins 1 and 2 (Scallen et al, 1971; Scallen et al, 1974), both found in rat liver, oxysterol-binding protein (Kandutsch et al, 1977) and cholesterol ester transfer protein (Wetterau and Zilversmit, 1984).

\section{Triacylglycerol binding proteins}

To date a single protein with binding capacities for triacylglycerol has been identified and isolated from bovine and rat liver (Wetterau and Zilversmit, 1984; Wetterau and Zilversmit, 1985; Wetterau and Zilversmit, 1986). Besides triacylglycerols this protein can bind cholesterol esters and, to a lesser extent, phosphatidylcholine.

\section{Glycolipid transfer proteins (GL-TP)}

About a decade ago a new group of proteins able to bind lipids containing a sugar residue was detected. Metz and Radin (1980) detected a factor in cytosol preparations of bovine spleen capable of transferring glucosylceramide between liposomes and erythrocyte membranes. A pure protein preparation was obtained from pig brain (Abe et al, 1982; Abe and Sasaki, 1985). A similar glycolipid transferring activity has now been detected in a variety of mammalian tissues (Sasaki et al, 1990).

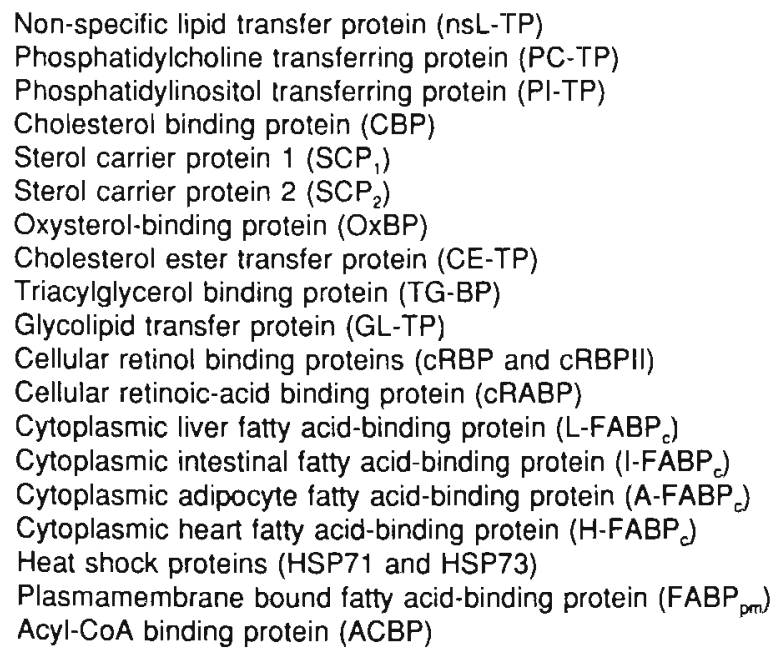

Table 2.1. Intracellular lipid binding proteins in mammalian tissues.

\section{Retinol and retinoid binding proteins}

Retinol (Vitamin A) and its derivates play an essential role in a number of biochemical processes (Sporn et al, 1984). Due to their chemical structure these substances are 
hydrophobic and most likely have to be transported bound to protein carriers. Besides a plasma retinol binding protein, three different intracellular proteins have been identified each binding retinol or retinol derivates, i.e. cellular retinol binding protein (cRBP), cellular retinol binding protein II (cRBPII) and cellular retinoic acid-binding protein (cRABP) present in a variety of mammalian tissue types (Eriksson, 1990). cRBP binds retinol whereas cRBPIl can bind both retinol and retinal. cRABP has a high affinity for retinoids with a carboxylic group.

\section{Fatty acid-binding proteins (FABP)}

Two decades ago the first reports on the existence of a small protein capable of binding long chain fatty acids in vitro appeared (Mishkin et al, 1972; Ockner et al, 1972). These investigators detected FA binding activity in cytosol preparations of rat liver, intestine, kidney, skeletal muscle, myocardium and adipose tissue. The knowledge of this group of proteins has expanded tremendously, mainly during recent years. In this and the next section some general characteristics of these proteins will be discussed, whereas for further detailed information the reader is referred to the various reviews which appeared during recent years (Bass, 1985; Glatz and Veerkamp, 1985; Bernier and Jollès, 1987; Sweetser et al, 1987; Veerkamp and Paulussen, 1987; Bass, 1988; Clarke et al,1989; Spener et al, 1989; Glatz and Van der Vusse 1990; Kaikaus et al, 1990; Matarese et al, 1990; Spener and Mukherjea, 1990; Paulussen and Veerkamp, 1990; Veerkamp et al, 1991).

To date at least four distinct cytoplasmic FABP types have been identified, viz. liver, intestinal, heart and adipocyte FABP. These proteins have a comparable molecular weight of 14-16 kDa, show a relatively high degree of primary structure similarity and all are able to bind fatty acids in vitro with a chain length of 16-22 carbon atoms. Based on primary structure similarity some other proteins can be regarded to be part of the FABP family, i.e. myelin P2, a protein present in the peripheral nerve myelin (Uyemura et al, 1984; Matarese et al, 1988), gastrotropin, present in the terminal ileum (Walz et al, 1988; Ganz et al, 1989), mammary derived growth inhibitor from bovine mammary gland (MDGl) (Böhmer et al, 1987) and the retinoid binding proteins $\mathrm{CRBP}, \mathrm{cRBP} \|$ and $\mathrm{CRABP}$ (see previous section). Besides these proteins, some other intracellular proteins can also bind FA, but do not show much structural homology to FABP i.e. 71 and $73 \mathrm{kDa}$ heat shock proteins (Guidon and Hightower, $1985 \mathrm{a}, \mathrm{b})$ and a $40 \mathrm{kDa}$ plasmalemmal bound FABP $\left(\mathrm{FABP}_{\mathrm{pm}}\right)$ (Stremmel et al, 1985). Finally, a $9.9 \mathrm{kDa}$ protein was isolated and characterized which can bind acyl-CoA (Mogensen et al, 1987; Knudsen, 1990) but not FA. Liver FABP (L-FABP) was found in liver, intestine, kidney and stomach (Paulussen et al, 1989; Bass and Manning, 1986; Paulussen et al, 1990; Gordon et al, 1985; Bass et al, 1985; Maatman et al, 1992), although the kidney protein was initially reported not to be completely similar to L-FABP (Maatman et al, 1991). Intestinal FABP (I-FABP) has been detected only in the small intestine (Bass et al, 1985; Bass and Manning, 1986). Adipose tissue contains another distinct FABP (A-FABP) (Bernlohr et al, 1984; Baxa et al, 1989) although this protein was found to cross-react with antibodies against liver and heart FABP (Paulussen et al, 1989).

The far most widespread FABP type is heart type FABP (H-FABP) which will be discussed in more detail in the next section. It can, beside the heart, be found in skeletal muscle (Claffey et al, 1987; Heuckeroth et al, 1987, Paulussen et al, 1989), kidney (Claffey et al, 1987; Heuckeroth et al, 1987; Lam et al, 1988; Maatman et al ,1991), stomach (Kanda et al, 1989), mammary gland (Jones et al, 1988), adrenal gland and placenta (Heuckeroth et al, 1987), testes (Bass and Manning, 1986) and aorta wall (Sarzani et al, 1988). Moreover, a protein with $95 \%$ immunological cross-reactivity with heart FABP was isolated from bovine brain (Schoentgen et al, 1989). 
Rat heart.

Mouse heart

Human heart

Bovine heart

Rat liver

Rat intestine

5

10

15

Ala Asp Ala phe Val Gly Thr Trp Lys Leu Val Asp Ser Lyo Asn Ala Asp Ala phe Val Gly Thr Trp Lys Leu Val Asp Ser Lys Asn Val. Asp Ala phe Leu Gly Thr Trp Lys Leu Val Asp Ser Lya ABn Val Asp Ala phe Val Gly Thr Trp Lys Leu Val Asp Ser Lys Asn Asn Phe Ser Gly Lys Tyr Gln Val Gln Ser Gln Glu Asn Phe Glu Ala Phe Asp Gly Thr Trp Lys Val Asp Arg Asn Glu Asn Tyr Glu

20

25

30

35

Phe Aвp Aвp Tyr Met Lys Ser Leu Gly Val Gly phe Ala Thr Arg Gln Val Ala Ser Met Phe Aap Aep Tyr Met Lyo Ser Leu Gly Val Gly phe Ala Thr Arg gln Val Gly Ser Met Phe Asp Asp Tyr Met Lys Ser Leu Gly Val Gly phe Ala Thr Arg Gln Val Ala ser Met Phe Asp Asp Tyr Met Lys Ser Leu Gly Val Gly phe Ala Thr Arg gin Val Gly Asn Met Pro Phe Met Lys Ala Met. Gly Leu Pro Glu Asp Leu Ile Gin Lys Gly Lys Asp Ile Lys Lys Phe Met Glu Lys Met. Gly Ile Asn Val Val Lys Arg Lys Leu Gly Ala His Asp Asn

40

45

50

55

Thr Lys Pro Thr Thr Ile Ile glu Lys ABn Gly Asp Thr Ile Thr Ile Lys Thr HAs Ser Thr Lys Pro Thr Thr Ile Ile Glu LyB ABn Gly Asp Thr Ile Thr Ile LyB Thr Gln Ser Thr Lys Pro Thr Thr Ile Ile Glu Lys Asn Gly Asp Ile Leu Thr Leu Lys Thr H1s Ser Thr Lys Pro Thr Thr Ile Ile Glu Val Asn Gly Asp Thr Val Ile Ile Lys Thr Gln Ser Gly Val Ser Glu Ile Val His Glu Gly Lys Lys Val Lys Leu Thr Ile Thr Tyr Gly Ser Leu Lys Leu Thr Ile Thr Gln Glu Gly Asn Lys Phe Thr Val Lys Glu Ser. Ser Asn Phe

60 65 70 75

Thr Phe Lyв Asn Thr Glu Ile Ser Phe Gln Leu Gly Val Glu Phe Asp Glu Val Thr Ala Thr phe Lya Aan Thr Glu Ile Asn phe Gln Leu Gly Ile Glu Phe Asp Glu Val Thr Ala Thr Phe Lys Asn Thr Glu Ile Ser Phe Lys Leu Gly Val Glu Phe Asp Glu Thr Thr Ala Thr phe Lys Asn Thr Glu Ile ser phe Lys Leu Gly Val Glu phe Asp Glu Thr Thr Ala Lys Val Ile His Asn Glu Phe Thr. Leu Gly Glu Glu Cys Glu Leu Glu Thr. Met Thr Gly Arg Asn Ile Asp Val Val Phe Glu Leu Gly Val Asp Phe Ala Tyr Ser Leu Ala Asp Gly

Asp Asp Arg Lys Val Lys Ser Val Val Thr Leu Asp Gly gly Lys Leu Val His Val Gln Asp Asp Arg Lys Val Lyo Ser Leu Val Thr Leu Asp gly gly Lys Leu Ile His Val gln Asp Asp Arg Lys Val Lys Ser Ile Val Thr Leu Asp Gly Gly Lys Leu Val His Leu Gln Asp Asp Arg Lys Val Lyв Ser Ile Val Thr Leu Asp Gly gly Lys Leu Val H1a Val Gln Glu Lys Val Lys Ala Val Val Lys Met Glu Gly Asp Asn Lys Met. Val Thr Thr Phe Lys Thr Glu Leu Thr Gly Thr Trp Thr Met Glu Gly Asn Lys Leu Val. Gly Lys Phe Lys Arg

$$
100 \quad 1.05 \quad 110
$$

115

Lyв Trp Asp Gly Gln Glu Thr Thr Leu Thr Arg Glu Leu Ser Asp gly Lyo Leu Ile Leu Lys Trp Aep Gly Gln Glu Thr Thr Leu Thr Arg Glu Leu Val Agp Gly Lys Leu Ile Leu Lys Trp Aep Gly Gln Glu Thr Thr Leu Val Arg Glu Leu Ile Asp gly Ly Leu Ile Leu Lys Trp Asn Gly Gln Glu Thr Ser Leu Val Arg Glu Met Val Asp Gly Lys Leu Ile Leu Gly Ile Lys Ser Val Thr Glu Phe Asn Gly Asp Thr Ile Thr Asn Thr Met Thr Leu Gly Val Asp Asn Gly Lys Glu Leu Ile Ala Val Arg Glu Ile Ser Gly Asn Glu Leu Ile Gln

$$
\begin{array}{llll}
120 & 125 & 130 & 132
\end{array}
$$

Thr Leu Thr His Gly Aen Val Val Ser Thr Arg Thr Tyr Glu LyB Glu Ala Thr Leu Thr Hig Gly Ser Val Val Ser Thr Arg Thr Tyr Glu LyB Glu Ala Thr Leu Thr His Gly Thr Ala Val Cys Thr Arg Thr Tyr Gln Lye Glu Ala Thr Leu Thr His Gly Thr Ala Val Cys Thr Arg Thr Tyr Glu Lys Gln Ala Asp Ile Val. Tyr Lys Arg Val Ser Lys Arg Ile

Thr Tyr Thr Tyr Glu Gly Val Glu Ala Lys Arg: Ile Phe Lys Lys Glu

Table 2.2: Primary amino acid structure of a selection of FABPs. FABP from mouse heart, human heart, bovine heart, rat liver and rat intestine are compared with the primary structure of rat FABP. Bold print indicates homology. Note the high homology among different species in the same FABP type and the poor homology between distinct FABP types in one species, i.e. the rat. 


\section{Characteristics of heart type fatty acid-binding protein (H-FABP)}

\section{Primary structure of $H-F A B P$}

The amino-acid sequence primary structure of H-FABP has been determined, using protein cleavage techniques, for rat (Sacchettini et al, 1986; Gibson et al, 1988; Kimura et al, 1989) and human H-FABP (Offner et al, 1988; Börchers et al, 1990), and, making use of nucleotide sequencing, for rat (Claffey et al, 1987; Heuckeroth et al, 1987), cattle (Billich et al, 1988) and mouse H-FABP (Tweedie and Edwards, 1989). These amino acid sequences are shown in Table 2.2. For comparison the primary structures of rat liver and intestinal FABPs (Gordon and Lowe, 1985) are also shown. A striking similarity between inter-species H-FABP can be observed. The highest homology of primary structure is found between rat and mouse H-FABP $(94 \%)$, whereas the lowest homology is found between mouse and human H-FABP, but still amounts to $86 \%$. On the other hand a poor sequence similarity among liver, intestinal and heart FABP in one species exists, indicating that these proteins are encoded on separate genes. As do all presently known members of the mammalian FABP family, $\mathrm{H}$-FABP carries an acetyl group at its $\mathrm{N}$-terminal amino acid (Bernier and Jollès, 1987). Moreover, a slight portion of H-FABP has been found to be phosphorylated (Nielsen and Spener, unpublished observation).

\section{Tertiary structure of H-FABP}

Detailed information on the tertiary structure of intestinal FABP (I-FABP) is available from the work of Sacchettini et al (1990) and Scapin et al (1992). They used recombinant DNA techniques to express large amounts of I-FABP in $E$. Coli. After crystallization of the protein they were able to unravel the structure of I-FABP from rat using X-ray diffraction at $1.2 \AA$ resolution. It consists of ten anti-parallel $B$-strands organised into two $B$-sheets. Furthermore it contains two $\alpha$-helices connecting the first and the second $\beta$-strand. In general the structure resembles a clam between the two halves of which a long chain fatty acid molecule can be bound. Thus FA is no longer directly in contact with the polar aqueous environment, but is almost completely buried in the protein molecule. On FA binding the structural conformation of the protein hardly changes. For bovine H-FABP the tertiary structure was determined at a resolution of $3.5 \AA$ (Müller-Fahrnow et al, 1991). Despite large primary structure differences between $\mathrm{H}-\mathrm{FABP}$ and I-FABP, the tertiary structure of $\mathrm{H}-\mathrm{FABP}$ appears similar to that of I-FABP, indicating that this structure may be important for the binding of hydrophobic ligands. Recently the structure of human H-FABP has also been shown to be similar to that of I-FABP (Scapin and Sacchettini, 1992).

\section{Localization of H-FABP}

$\mathrm{H}-\mathrm{FABP}$ is primarily located in the cytoplasm of the cardiomyocyte (Paulussen et al, 1989) although it has also been shown immunocytochemically to be associated with myofibrils, mitochondria and the nucleus in rat (Fournier and Rahim, 1985) and bovine heart (Börchers et al, 1989). Unlike other species, bovine heart contains two isoforms of H-FABP, with iso-electric points of 4.9 and 5.1 respectively (Jagschies et al, 1985). Underberg et al (1990) showed that these isoforms only differ in one amino acid residue ( $\mathrm{Asn}^{98}$ in $\mathrm{pl} 5.1$. FABP versus $A s p^{98}$ in $\mathrm{pl} 4.9-\mathrm{FABP}$ ). They indicated that this amino acid modification may occur non-enzymatically. Interestingly, only the pl 4.9 isoform could be demonstrated in mitochondria. 
Several techniques to monitor FA binding by FABP have been used during recent years. Most of these techniques are based on the separation between FABP-bound and unbound FA after installation of a binding equilibrium. This can be performed by using relatively large particles with a moderate FA binding affinity, so that after binding of unbound FA these particles can be separated from the aqueous protein solution by centrifugation. For this Sephadex G-25 (Ockner and Manning, 1974), dextran-gelatin-coated charcoal (Morrow and Martin, 1983) and Lipidex 1000 (Glatz and Veerkamp, 1983) have been used. Glatz and Veerkamp (1983) showed that Lipidex 1000 is superior in comparison with the other substances. Another method to determine the stoichiometry of FA binding by FABP is to monitor the distribution of FA between PL vesicles and FABP (Offner et al, 1986; Paulussen et al, 1988). Unfortunately, although applicable for the qualitative monitoring of FA binding, each of these different techniques may give rise to confusion regarding the true stoichiometry and affinity of FA binding by FABP, since they each require separation of FABP-bound and non FABP-bound FA.

Nuclear magnetic resonance (NMR) has also been used to monitor FA binding by FABP (Cistola et al, 1988; Cistola et al, 1989; Cistola et al, 1990). The advantage of this technique is that it does not require separation of FABP-bound and non FABP-bound FA, making it a powerful tool to assess the FA binding parameters. Although some studies report a 2:1 binding stoichiometry for FA binding by H-FABP (Offner et al, 1986; Srimani et al, 1990 ) it is generally accepted that H-FABP and I-FABP only bind one FA molecule, whereas L-FABP can, among other ligands (Glatz and Van der Vusse 1990; Kaikaus et al, 1990; Matarese et al, 1990; Paulussen and Veerkamp, 1990; Veerkamp et al, 1991), bind 2-3 FA molecules (Cistola et al, 1989).

\section{Self aggregation of $H-F A B P$}

Heart-type FABP from pig and rat heart has been reported to form aggregates at concentrations higher than $2 \mathrm{mg}$ FABP per ml (Fournier et al, 1983; Fournier and Rahim, 1983; Fournier and Rahim, 1985; Fournier and Richard, 1988). These authors indicate that self-aggregation may play an important role in the activation of FA and acyl-CoA dependent mitochondrial membrane enzymes. To date, only Jones et al (1988) were able to partially reproduce these results, whereas no self-aggregation was observed of human (Offner et al, 1988), rat (Offner et al, 1986), and bovine (Jagschies et al, 1985) heart-type FABP. Nevertheless, the self-aggregation might be species and concentration dependent.

\section{Diurnal variation in H-FABP content}

Glatz and co-workers (1984) found that the H-FABP content in rat heart showed a diurnal variation, being highest in the mid-dark phase, in combination with a variation in palmitate oxidation capacity, indicating a close relationship between these two parameters and hence a possible important function of H-FABP in intracardial lipid metabolism.

\section{Evidence for FABP mediated FA transport in vitro}

Limited experiments have been performed to study the putative FA transport function of FABP. It was found by Catala and Avanzati (1983) and by McCormack and Brecher (1987) that liver FABP increased the FA transport between liposomes and microsomes. 
Peeters and Veerkamp (1989) studied the exchange of labeled FA from mitochondria to vesicles separated by a polycarbonate membrane through which these structures could not diffuse. They found that FABP, either liver type or heart type, could enhance the exchange rate of oleic acid between the two compartments. Similar results were found in a system in which the FA transfer between two separated phospholipid monolayers was studied, indicating that FABP might be involved in intracellular FA translocation. The exchange of fluorescently labeled FA from FABP to liposomes was studied in detail by Storch (1990). She found appreciable differences in the exchange velocity from liver $F A B P$ in comparison with heart FABP, the latter being approximately 50 fold higher. This finding might indicate physiological differences between the two proteins.

\section{Evidence for FABP mediated FA transport in vivo}

Studies have been performed to monitor intracellular FA binding by FABP (Waggoner and Bernlohr, 1990; Waggoner et al, 1991). These investigators incubated either adipose cells or liver cells with a FA analogue labeled with both a radioactive and a photoreactive group. After incubation with the FA cells were irradiated with UV-light after which covalent binding to proteins was monitored. It was found that FABP in these cells was labeled with the FA. This was the first direct evidence that FABP binds FA in vivo and possibly indicates an important FA transport function of FABP.

\section{REFERENCES}

Abe A, Yamada K, Sasaki T. 1982. A protein purified from pig brain accelerates the intermembranous translocation of mono- and dihexosylceramides, but not the translocation of phospholipids. Biochem Biophys Res Commun 104, 1386-1393.

Abe A, Sasaki T. 1985. Purification and some properties of the glycolipid transfer protein from pig brain. J Biol Chem 260, 11231-11239.

Bass NM. 1985. Function and regulation of hepatic and intestinal fatty acid binding proteins. Chem Phys Lipids 38, 95-114.

Bass NM, Manning JA, Ockner RK, Gordon JI, Seetharam S, Alpers DH. 1985. Regulation of the biosynthesis of two distinct fatty acid-binding proteins in rat liver and intestine: Influence of sex difference and of clofibrate. $J$ Biol Chem 260, 1432-1436

Bass NM, Manning JA. 1986. Tissue expression of three structurally different fatty acid binding proteins from rat heart muscle, liver and intestine. Biochem Biophys Res Commun 137, 929-935.

Bass NM. 1988. The cellular fatty acid-binding proteins: Aspects of structure, regulation and function. Int Rev Cytol 111, 143-184

Baxa CA, Sha RS, Buelt MK, Smith AJ, Matarese V, Chinander LL, Boundy KL, Bernlohr DA. 1989. Human adipocyte lipid binding protein: Purification of the protein and cloning of its complementary DNA. Biochemistry 28, 8683-8690.

Bernlohr DA, Angus CW, Lane MD, Bolanowski MA, Kelly TJ Jr. 1984. Expression of specific mRNAs during adipose differentiation. Identification of an mRNA encoding a homologue of myelin p2 protein. Proc Nat Acad Sci USA 81, 5468-5472.

Bernler I, Jolles P. 1987. A survey on cytosolic non-enzymatic proteins involved in the metabolism of lipophilic compounds: trom organic anion binders to new protein families. Biochimie 69, 1127-1152.

Billheimer JT, Reinhart MP. 1990. Intracellular sterol transpont. In: Subcellular Biochemistry Vol. 16: Intracellular transfer of lipid molecules. Ed. H.J. Hilderson, pp 69-111. Plenum press, New York and London. Blllich S, Wissel T, Kratzin H, Hahn U, Hagendorff B, Lezius AG, Spener F. 1988. Cloning of a full-length complementary DNA for fatty acid-binding protein from bovine heart. Eur J Biochem 175, 549-556.

BIsgaier CL, Glickman RM. 1983. Intestinal synthesis, secretion and transport of lipoproteins. Ann Rev Physiol 45, 625-636.

Bloj B, Zilversmit DB. 1977. Rat liver proteins capable of transferring phosphatidylethanolamine. Purification and transfer activity for other phospholipids and cholesterol. J Biol Chem 252, 1613-1619. 
Böhmer F-D. Sun Q, Pepperle M, Müller T, Eriksson U, Wang JL, Grosse R. 1987. Antibodies against Mammary-Derived Growth Inhibitor (MDGI) react with a fibroblast growth inhibitor and with heart fatty acidbinding protein. Biochem Biophys Res Commun 148, 1425-1431.

Börchers T, Underberg C, Rüdel H, Robenek H, Spener F. 1989. Subcellular distribution of cardiac fatty acid. binding protein in bovine heart muscle and quantification with an enzyme linked immunosorbent assay. Biochim Biophys Acta 1002, 54-61.

Börchers T, Hфjrup P, Nielsen SU, Roepstortf P, Spener F, Knudsen J. 1990. Revision of the amino acid sequence of human heart fatty acid-binding protein. Mol Cell Biochem 98, 127-133.

Borgström B. 1974. Bile salts-their physiological functions in the gastro-intestinal tract. Acta Med Scand 196, $1-10$.

Brindley DN. 1974. The intracellular phase of fat absorption. Biomembranes 4B, 621-671.

Brindley DN. 1991. Metabolism of triacylglycerols. In: Biochemistry of lipids, lipoproteins and membranes, pp 427-459. Ed. Vance DE, Vance J. Elsevier Science Publishers, Amsterdam, The Netherlands.

Brodersen R, Vorum H, Skriver E, Pedersen AO. 1990. Serum albumin binding of palmitate and stearate. Eur J Biochem 182, 19-25.

Catala A, Avanzati B. 1983. Oleic acid transfer from microsomes to egg lecithin liposomes: participation of fatty acid-binding protein. Lipids 18, 803-807.

Cistola DP, Sacchettini JC, Gordon Jl. 1989. Fatty acid interaction with rat intestinal and liver fatty-acid binding proteins expressed in Escherichia coli. A comparative ${ }^{13} \mathrm{C}$ NMR study. J Biol Chem 264, 2700-2710.

Chanderbhan R, Noland BJ, Scallen TJ, Vahouny GV. 1982. Sterol carrier protein 2 delivery of cholesterol from adrenal lipid droplets to mitochondria for pregnenolone synthesis. J Biol Chem 257, 8928-8934.

Claffey KP, Herrera VL, Brecher P, Ruiz-Opaza N. 1987. Cloning and tissue distribution of rat heart fatty acidbinding protein mRNA: Identical forms in heart and skeletal muscle. Biochemistry 26, 7900-7904.

Clarke SD, Armstrong MK. 1989. Cellular lipid binding proteins: expression, function and nutritional regulation. Faseb J 3, 2480-2487.

Cryer A. 1989. The role of the endothelium in myocardial lipoprotein dynamics. Mol Cell Biochem 88, 7-154.

Davies RA. 1991. Lipoprotein structure and secretion. In: Biochemistry of lipids, lipoproteins and membranes, pp 403-426. Ed. Vance DE, Vance J. Elsevier Science Publishers, Amsterdam., The Netherlands.

Desnuelle P. 1961. Pancreatic lipase. Adv Enzymol 23, 129-161.

DiCorleto PE, Warach JB, Zilversmit DB. 1979. Purification and characterization of two phospholipid exchange proteins from bovine heart. J Biol Chem 254, 7795-7802.

Eisenberg S, Levy RI. 1975. Lipoprotein metabolism. Adv Lipid Res 13, 1-89.

Erickson SK, Meyer DJ, Gould RG. 1978. Purification and characterization of a new cholesterol binding protein from rat liver cytosol. J Biol Chem 253, 1817-1826.

Eriksson U. 1990. Extra- and intracellular transport of retinoids. In: Subcellular Biochemistry Vol. 16: Intracellular transfer of lipid molecules. Ed. H.J. Hilderson, pp 365-399. Plenum press, New York and London. Felts JM. 1975. Clearance of plasma lipoproteins: Role of lipoprotein lipase, lecithin-cholesterol acyl transferase, and the effect of drugs. In: International Encyclopedia of pharmacology and therapeutics. Pharmacology of lipid transport and atherosclerotic processes, ed. EJ Masoro, Sect 24, 1, 375-402. Oxford, Pergamon.

Flelding PE, Fielding CJ. 1991. Dynamics of lipoprotein transport in the circulatory system. In: Biochemistry of lipids, lipoproteins and membranes, pp 427-459. Ed. Vance DE, Vance J. Elsevier Science Publishers, Amsterdam, The Netherlands.

Fournier NC, Rahim MH. 1983. Self-aggregation, a new property of cardiac fatty acid-binding protein. Predictable influence on energy production in the heart. 1983. J Biol Chem 258, 2929-2933

Fournier NC, Zuker M, Williams RE, Smith ICP. 1983. Self-aggregation of the cardiac fatty acid-binding protein. Influence on membrane-bound, fatty acid dependent enzymes. Biochemistry 22, 1896-1872.

Fournier NC, Rahim M. 1985. Control of energy production in the heart: A new function for fatty acid-binding protein. Biochemistry 24, 2387-2396.

Fournier NC, Richard MA. 1988. Fatty acid-binding protein, a potential regulator of energy production in the heart. J Biol Chem 263, 14471-14479.

Gantz I, Nothwehr SF, Lucey M, Sacchettini JC, DelValle J, Banaszak LJ, Naud M, Gordon Jl, Yamada T. 1989. Gastrotropin: Not an enterooxyntin but a member of a family of cytoplasmic hydrophobic ligand binding proteins. J Biol Chem 264, 20248-20254.

Gavey KL, Noland BJ, Scallen TJ. 1981. The participation of sterol carrier protein 2 in the conversion of cholesterol to cholesterol ester by rat liver microsomes. J Biol Chem 256, 2993-2999. 
George PY, Helmkamp GM Jr. 1985. Purification and characterization of a phosphatidylinositol transfer protein from human platelets. Biochim Biophys Acta 836, 176-184.

Gibson BW, Yu Z, Aberth W, Burlingame AL, Bass NM. 1988. Revision of the blocked N terminus of rat heart fatty acid-binding protein by liquid secondary ion mass spectrometry. J Biol Chem 263, 4182-4185.

Glatz JFC, Veerkamp JH. 1983. A radiochemical procedure for the assay of fatty acid binding by proteins. Anal Biochem 132, 89-95.

Glatz JFC, Veerkamp JH. 1985. Intracellular fatty acid-binding proteins. Int J Biochem 17, 13-22.

Glatz JFC, Baerwaldt CCF, Veerkamp JH, Kempen HJM. 1984. Diurnal variation of cytosolic fatty acid-binding protein content and of palmitate oxidation in rat liver and heart. J Biol Chem 259, 4295-4300.

Glatz JFC, Van der Vusse GJ. 1990. Cellular fatty acid-binding proteins: Current concepts and future directions. Mol Cell Biochem 98, 237-251.

Goodman DS. 1958. The interaction of human serum albumin with long-chain fatty acid anions. J Amer Chem Soc 80, 3892-3898.

Gordon JI, Lowe JB. 1985. Analyzing the structures, functions and evolution of two abundant gastro-intestinal fatty acid-binding proteins with recombinant DNA and computational techniques. Chem Phys Lipids 38, 137158.

Gordon Jl, Elhourbagy N, Lowe JB, Liao S, Alpers DH, Taylor JM. 1985. Tissue specific expression and developmental regulation of two genes encoding for rat fatty acid-binding proteins. J Biol Chem 260, 1995 1998.

Groot PHE, Oerlemans MC, Scheek LM. 1979. Triglyceridase and phospholipase A1 activities of rat heart lipoprotein lipase. Influence of apolipoprotein C-II and C-III. Biochim Biophys Acta 530, 91-98.

Guidon PT Jr, Hightower LE. 1986a. Purification and initial characterization of the 71-kilodalton rat heat-shock protein and its cognate as fatty acid binding protein. Biochemistry 25, 3231-3239.

Guidon PT Jr, Hightower LE. 1986b. The 73 kilodalton heat shock cognate protein purified from rat brain contains non-esterified palmitic and stearic acid. J Cell Physiol 128, 239-245.

Hamilton RL. 1972. Synthesis and secretion of plasma lipoproteins. Adv Exp Med Biol 26, 7-24.

Havel RJ. 1972. Caloric homeostasis and disorders of fuel transport. N Eng J Med 287, 1186-1192.

Havel RJ, Kane JP, Kashyap ML. 1973. Interchange of apolipoproteins between chylomicrons and high density lipoproteins during alimentary lipemia in man. $\mathrm{J}$ Clin Invest 52, 32-38.

Haunerland N, Chisholm JM. 1990. Fatty acid-binding protein in flight muscle of the locust Schistocerca gregoria. Biochim Biophys Acta 1047, 233-238.

Heuckeroth RO, Birkenmeister EH, Levin MS, Gorden Jl. 1987. Analysis of the tissue-specific expression, developmental regulation and linkage relationships of a rodent gene encoding heart fatty acid-binding protein. J Biol Chem 262, 9709-9717.

Higgins JM, Fielding CJ. 1975. Lipoprotein lipase. Mechanism of formation of triglyceride-rich remnant particles from very low density lipoproteins and chylomicrons. Biochemistry 14, 2288-2293.

Helmkamp GM Jr, Harvey MS, Wirtz KWA, Van Deenen LLM. 1974. Phospholipid exchange between membranes. Purification of bovine brain proteins that preferentially catalyze the transfer of phosphatidylinositol. J Biol Chem 249, 6382-6389.

Higuchi K, Hayakawa M, Yoshimitsu A, Hirotsugu. 1981. Comparative studies on a heat-stable cholesterolbinding protein in dental cyst fluid and serum. Int J Biochem 13, 777-782.

Jackson MJ. 1974. Transport of short chain fatty acids. Biomembranes 4B, 673-709.

Jackson RL, Morrisett JD, Gotto AM. 1977. Lipoproteins and lipid transport: Structural and functional concepts. In: Hyperlipidaemia. Diagnosis and Therapy. Eds. Rifkind BM and Levy RI. pp 1-16. Grune and Stratton, New York, USA.

Jagschies G, Reers $M_{1}$, Underberg C, Spener F. 1985. Bovine fatty acid proteins: Isolation and characterization of two cardiac fatty acid binding proteins that are distinct from corresponding hepatic proteins. Eur J Biochem 152, 537-545.

Jones NL, Havel RJ. 1967. Metabolism of free fatty acids and chylomicrons during exercise in rats. Am J Physiol 213, 824-828.

Jones PD. Carne A, Bass NM, Grigor MR. 1988. Isolation and characterization of fatty acid-binding protein from mammary tissue of lactating rats. Biochem J 251, 919-925.

Khoo JC, Aquino AA, Steinberg D. 1974. The mechanism of activation of hormone sensitive lipase in human adipose tissue. J Clin Invest 53, 1124-1131.

Kader JC. 1990. Intracellular transfer of phospholipids, galactolipids and fatty acids in plant cells. In: Subcellular Biochemistry Vol. 16: Intracellular transfer of lipid molecules. Ed. H.J. Hilderson, pp 69-111. Plenum press, New York and London. 
Kamp HH, Wirtz KWA, Van Deenen LLM. 1973. Some properties of phosphatidylcholine exchange protein purified from beef liver. Biochim Biophys Acta 318, 3134-325.

Kaikaus RM, Bass NM, Ockner RK. 1990. Functions of fatty acid binding proteins. Experientia 46, 617-630. Kanda T, Iseki S, Hitomi M, Kimura H, Odani S, Kondo H, Matsubara Y, Muto T, Ono T. 1989. Purification and characterization of a fatty acid-binding protein from the gastric mucosa of rats. Possible identity with heart fatty acid-binding protein and its parietal cell localization. Eur J Biochem 185, 27-33.

Kandutsch AA, Chen HW, Shown EP. 1977. Binding of 25-hydroxycholesterol and cholesterol to different cytosolic proteins. Proc Natl Acad Sci USA 74, 2500-2503.

Kimura H, Hitomo M, Odani S, Koide T, Arakawa M, Ono T. 1989. Rat heart fatty acid-binding protein. Evidence that supports the amino acid sequence predicted from the cDNA. Biochem J 260, 303-306.

Knudsen J. 1990. Acyl-CoA-binding protein (ACBP) and its relation to fatty acid-binding protein (FABP): An overview. Mol Cell Biochem 98, 217-223.

Kragh-Hansen U. 1981. Molecular aspects of ligand binding to serum albumin. Pharmacol Rev 33, 17-53. Kreisberg RA. 1966. Effect of diabetes and starvation on myocardial triglyceride and free fatty acid utilization. Am J Physiol 210, 379-384.

Lam KT, Borkan S, Claffey KP, Schwartz JH, Chobanian AV, Brecher P. 1988. Properties and differential regulation of two fatty acid-binding proteins in the rat kidney. J Biol Chem 263, 15762-15768.

LeFevre A, Morera AM, Saez JM. 1978. Adrenal cholesterol-binding protein: properties and partial purification. FEBS Lett 89, 287-292.

Maatman RGHJ, Van Kuppevelt THMSM, Veerkamp JH. 1991. Two types of fatty acid-binding proteins in human kidney: Isolation, characterization and localization. Biochem J 273, 759-766.

Maatman RGHJ, Van de Westerlo EMA, Van Kuppevelt THMSM, Veerkamp JH. 1992. Liver type fatty acidbinding protein is present in human and rat kidney (abstract). Abstractbook 2nd Int Workshop on FABP, Maastricht, p.56.

Mahley RW, Bennett BD, Morre DJ, Gray ME, Thistlewaite W, LeQuire VS. 1971. Lipoproteins associated with the Golgi apparatus isolated from epithelial cells of rat small intestine. Lab Invest 25, 435-444.

Masoro EJ. 1977. Lipids and lipid metabolism. Annu Rev Physiol 39, 301-321.

Matarese V, Bernlohr DA. 1988. Purification of murine adipocyte lipid-binding protein. J Biol Chem 263, 1454414551.

Matarese V, Stone RL, Waggoner DW, Bernlohr DA. 1990. Intracellular fatty acid trafticking and the role of cytosolic lipid binding proteins. Prog Lipid Res 28, 245-272.

McCormack M, Brecher P. 1987. Effect of liver fatty acid-binding protein on fatty acid movement between liposomes and rat liver microsomes. Biochem J 244, 717-723.

Metz RJ, Radin NS, 1980. Glucosylceramide uptake protein from spleen cytosol. J Biol Chem 255, 4463-4467. Mishkin S, Stein L, Gatmaitan Z, Arias IM. 1972. The binding of fatty acids to cytoplasmic proteins: binding to $Z$ protein in liver and other tissues of the rat. Biochem Biophys Res Commun 47, 997-1003.

Mogensen IB, Schulenberg H, Hansen HO, Spener F, Knudsen J. 1987. A novel acyl-CoA binding protein from bovine liver. Biochem J 241, 189-192.

Morrow FD, Martin RJ. 1983. Quantitation of hepatic fatty acid-binding proteins by post-chromatographic ligand binding assay. J Lipid Res 24, 324-331.

Müller-Fahrnow A, Egner U, Jones A, Rüdel H, Spener F, Saenger W. 1991. Three-dimensional structure of fatty acid-binding protein from bovine heart. Eur J Biochem 199, 271-276.

Ockner RK, Manning JA, Poppenhausen RB, Ho WKL. 1972. A binding protein for fatty acids in cytosol of intestinal mucosa, liver, myocardium and other tissues. Science 177, 56-58.

Ockner RK, Manning JA. 1974. Fatty acid-binding protein in small intestine: identification, isolation and evidence for its role in cellular fatty acid transport. J Clin Invest 54, 326-338.

Offner GD, Troxler RF, Brecher P. 1986. Characterization of a fatty acid-binding protein from rat heart. J Biol Chem 261, 5584-5589.

Offner GD, Brecher P, Sawlivich WB, Costello CE, Troxier RF. 1988. Characterization and amino acid sequence of a fatty acid-binding protein from human heart. Biochem J 252, 191-198.

Ohta M, Yamano T, Miyake Y. 1982. Purification and some properties of a new cholesterol binding protein from rat liver cytosol. Biomed Res 3, 239-243.

Paltauf F, Daum G. 1990. Phospholipid transfer in microorganisms. In: Subcellular Biochemistry Vol. 16: Intracellular transfer of lipid molecules. Ed. H.J. Hilderson, pp 279-299. Plenum press, New York and London. Paulussen RJA, van der Logt CPE, Veerkamp JH. 1988. Characterization and binding properties of fatty acidbinding proteins from human, pig and rat heart. Arch Biochem Biophys 264, 533-545. 
Paulussen RJA, Geelen M.JH, Beynen AC, Veerkamp JH. 1989. Immunochemical quantitation of fatty acidbinding proteins. I. Tissue and intracellular distribution, postnatal development and influence of physiological conditions on rat heart and liver FABP. Biochim Biophys Acta 1001, 201-209.

Paulussen RJA, Veerkamp JH. 1990. Intracellular fatty acid-binding proteins. Characteristics and function. In: Subcellular Biochemistry Vol. 16: Intracellular transfer of lipid molecules. Ed. H.J. Hilderson, pp 175-226. Plenum press, New York and London.

Paulussen RJA, Van Moerkerk HTB, Veerkamp JH. 1990. Immunological quantification of fatty acid-binding proteins. Tissue distribution of liver and heart FABP types in human and porcine tissues. Int $\mathrm{J}$ Biochem 22 , 393-398.

Peeters RA, Veerkamp JH. 1989. Does fatty acid-binding protein play a role in fatty acid transport ? Mol Cell Biochem 88, 45-49.

Peters T. 1985. Serum albumin. Adv Prot Chem 37, 161-245.

Poorthuis BJHM, Van Der Krift TP. Teerlink T, Akeroyd R, Hostetler KY, Wirtz KWA. 1980. Phospholipid transfer activities in Morris hepatomas and the specific contribution of the phosphatidylcholine exchange protein. Biochim Biophys Acta 600, 376-386.

Potter BJ, Sorrentino D, Berk PD. 1989. Mechanisms of cellular uptake of free fatty acids. Annu Rev Nutr $\mathbf{9}$, 253-270.

Rothschild MA, Oratz M, Schreiber SS. 1988. Serum albumin. Hepatology 8, 385-401.

Sacchettini JC, Said B, Schultz H, Gordon JI. 1986. Rat heart fatty acid-binding protein is highly homogeneous to the murine adipocyte 422 protein and the $\mathrm{p} 2$ protein of peripheral nerve myelin. $\mathrm{J}$ Biol Chem $261,8218-8223$.

Sacchettini JC, Banaszak LJ, Gordon JI. 1990. Expression of rat intestinal fatty acid-binding protein in E. Coli and its subsequent structural analysis: a model system for studying the molecular details of fatty acid-protein interaction. Mol Cell Biochem 98, 81-93.

Sarda L, Desnuelle P. 1958. Action de la lipase pancréatique sur les esters en emulsion. Biochim Biophys Acta 30, 513-521.

Sarzani R, Claffey KP, Chobanian AV, Brecher P. 1988. Hypertension induces tissue specific gene suppression of a fatty acid-binding protein in rat aorta. Proc Nat Acad Sci USA 85, 7777-7781.

Sasaki T, Abe A, Roerink F. Glycolipid transfer protein in animal cells. In: Subcellular Biochemistry Vol. 16: Intracellular transfer of lipid molecules. Ed. H.J. Hilderson, pp 113-127. Plenum press, New York and London. Scallen TJ, Schuster MW, Dhar AK, Skirdlant HB. 1971. Enzymatic synthesis of cholesterol: Use of a liver acetone powder. Lipids 6, 162-164.

Scallen TJ, Srikantaiah MV, Seetharam B, Hansbury E, Gavey KL. 1974. Sterol carrier protein hypothesis. Fed Proc 33, 1733-1746.

Scapin G, Sacchettini JC. 1992. Three-dimensional structure of human muscle fatty acid-binding protein. Refinement of the stearic acid-MFABP complex at 1.3 A resolution (abstract). Abstractbook 2nd Int Workshop on FABP, p.42.

Scapin G, Gordon Jl, Sacchettini JC. 1992. Refinement of the structure of recombinant rat intestinal fatty acidbinding apoprotein at 1.2 A resolution. I Biol Chem 267, 4253-4269.

Schneider WJ. 1991. Removal of lipoproteins from plasma. In: Biochemistry of lipids, lipoproteins and membranes, pp 461-487. Ed. Vance DE, Vance J. Elsevier Science Publishers, Amsterdam, The Netherlands. Schoentgen F, Pignène G, Bonanno LM, Jölles P. 1989. Fatty acid-binding protein from bovine brain: Amino acid sequence and some properties. Eur J Biochem 185, 35-40.

Shiau Y-F. 1987. Lipid digestion and absorption. In: Physiology of the gastrointestinal tract, chapter 56. Ed. Johnson LR. Raven Press, New York, USA.

Siddle K and Halis CN. 1975. Hormonal control of adipose tissue lipolysis. Proc Nutr Soc 34, 117-140.

Smith LC, Scow RO. 1979. Chylomicrons. Mechanisms of transfer of lipolytic products to cells. Prog Biochem Pharmacol 15, 109-138.

Spector AA, John K, Fletcher JE. 1969. Binding of long-chain fatty acids to bovine serum albumin. J Lipid Res 10, 56-67.

Spector AA. 1986. Plasma albumin as a lipoprotein. In: Biochemistry and biology of plasma lipoproteins. Ed. Scanu A, Spector AA. pp 247-279, Marcel Dekker, New York ,USA.

Spener F, Börchers T, Mukherjea M. 1989. On the role of fatty acid-binding proteins in fatty acid transport and metabolism. FEBS Lett 244, 1-5.

Spener F, Mukherjea M. 1990. Nonenzymatic proteins mediating lipid transport and metabolism: current status and emerging trends. In: Subcellular Biochemistry Vol. 16: Intracellular transfer of lipid molecules. Ed. H.J. Hilderson, pp 1-19. Plenum press, New York and London. 
Sporn MB, Roberts AB, Goodman DS (Eds). 1984. The retinoids. Academic press, Orlando, USA.

Srimani BN, Engelman RM, Jones R, Das D. 1990. Protective role of intracoronary fatty acid-binding protein in ischemic and reperfused myocardium. Circ Res 66, 1535-1543.

Storch J. 1990. A comparison of heart and liver fatty acid-binding proteins: interactions with fatty acids and possible functional differences studied with fluorescent fatty acid analogues. Mol Cell Biochem 98, 141-147. Stremmel W, Strohmeyer G, Borchard F, Kochwa S, Berk P. 1985. Isolation and partial characterization of a fatty acid-binding protein in rat liver plasma membranes. Proc Nat Acad Sci USA 82, 4-8.

Stryer L. 1988. Biochemistry 3rd ed. Freeman Co., New York, USA.

Sweetser DA, Heuckeroth RO, Gordon JI. 1987. The metabolic significance of mammalian fatty acid-binding protein: Abundant proteins in search of a function. Annu Rev Nutr 7, 337.359.

Sziegoleit A. 1982. Purification and characterization of a cholesterol-binding protein from human pancreas. Biochem J 207, 573-582.

Tweedie S, Edwards Y. 1989. cDNA sequence for mouse hean fatty acid-binding protein, H-FABP. Nucl Acid Res 17, 4374.

Underberg C, Börchers T, Hфjrup P, Roepstorff P, Knudsen J, Spener F. 1990. Cardiac fatty acid-binding proteins: Isolation and characterization of the mitochondrial fatty acid-binding protein and its structural relationship with the cytosolic isoforms. J Biol Chem 265, 16255-16261.

Uyemura K, Yoshimura K, Suzuki M, Kitamura K. 1984. Lipid-binding activities of the P2 protein in peripheral nerve myelin. Neurochem Res 9, 1509-1514.

Vance DE, Vance $J(E d$.$) . 1991. Biochemistry of lipids, lipoproteins and membranes. Elsevier Science$ Publishers, Amsterdam, The Netherlands.

Veerkamp JH, Paulussen RJA. 1987. Fatty acid transport in muscle: the role of fatty acid-binding proteins. Biochem Soc Trans 15, 331-336.

Veerkamp JH, Peeters RA, Maatman RGHJ. 1991. Structural and functional features of different types of cytoplasmic fatty acid-binding proteins. Biochim Biophys Acta 1081, 1-24.

Vorum H, Brodersen R, Kragh-Hansen U, Pedersen AO. 1992. Solubility of long-chain fatty acids in phosphate buffer at pH 7.4. Biochim Biophys Acta 1126, 135-142.

Waggoner DW, Bernlohr DA. 1990. In situ labeling of the adipocyte lipid binding protein with 3-[25|]lodo-4azido- $N$-hexadecylsalicylamide. J Biol Chem 265, 11417-11420.

Waggoner DW, Manning JA, Bass NM, Bernlohr DA. 1991. In situ binding of falty acids 10 the liver falty acid binding protein: Analysis using 3-[ $\left.{ }^{125} \mid\right]$ lodo-4-azido- $N$-hexadecy/salicylamide. Biochem Biophys Res Commun $180,407-415$.

Walz DA, Wider MD, Snow JW, Dass C, Desiderio DM. 1988. The complete amino acid sequence of porcine gastrotropin, an ileal protein which stimulates gastric acid and pepsinogen secretion. J Biol Chem 263, 14189 14195.

Wetterau JR, Zilversmit DB. 1984. A triglyceride and cholesteryl ester transfer protein associated with liver microsomes. J Biol Chem 259, 10863-10866.

Wetterau JR, Zilversmit DB. 1985. Purification and characterization of microsomal triglyceride and cholesteryl ester transfer protein from bovine liver microsomes. Chem Phys Lipids 38, 205-222.

Wetterau JR, Zilversmit DB. Localization of intracellular triacylglycerol and cholesteryl ester transfer activity in rat tissues. Biochim Biophys Acta 875, 610-617.

Wirtz KWA, Zilversmit DB. 1968. Exchange of phospholipids between liver mitochondria and microsomes in vitro. J Biol Chem 243, 3596-3602.

Wirtz KWA. 1991. Phospholipid transfer proteins. Annu Rev Biochem 60, 73-99.

Zilversmit DB. 1967. Formation and transport of chylomicrons. Fed Proc 26, 1599-1605. 
CHAPTER 3

\section{ASSAY OF THE BINDING OF FATTY ACIDS BY PROTEINS: EVALUATION OF THE LIPIDEX 1000 PROCEDURE*}

Michaël M. Vork, Jan F.C. Glatz, Don A.M. Surtel and Ger J. Van der Vusse.

'Mol Cell Biochem 98, 111-117, 1990 (reprinted with permission) 


\section{SUMMARY}

Fatty acid ( $F A$ ) binding by fatty acid-binding protein (FABP) is frequently monitored with the so-called Lipidex 1000 assay, in which protein associated and non-protein bound FA are separated by selectively binding the latter to Lipidex 1000 . Careful evaluation of this assay showed that the use of aqueous FA solutions resulted in a marked decrease (60 to $70 \%$ ) of FA concentration due to their aspecific binding to the surface of the test-tube used. In addition, solutions of rat heart FABP in the $\mu$ molar range also showed a concentration decrease up to $80 \%$ due to protein binding to the surface of the test-tube.

Introduction of detergents, Triton X-100 or Tween 20, limited the FA loss to less than $20 \%$ and totally eliminated FABP adsorption. Kinetic parameters for the binding of [1 ${ }^{14} \mathrm{C}$ ]oleic acid by purified rat heart FABP, assayed in the presence of Triton X-100, were found to be similar to those assayed in the absence of detergent, when adequate corrections were made for losses of FA and FABP due to surface adsorption. Use of Tween 20 resulted in a substantial increase of the dissociation constant. The addition of $100 \mu \mathrm{M}$ Triton X-100 to the assay medium considerably facilitates the determination of kinetic parameters of fatty acid binding by proteins.

\section{INTRODUCTION}

In 1983, Glatz and Veerkamp (1983a) introduced a radiochemical procedure for the determination of the non-covalent binding of long-chain fatty acids (FA) by proteins. Lipidex 1000 , a $10 \%$ substituted hydroxyalkoxypropyl derivate of Sephadex G-25, which shows appreciable affinity for hydrophobic substances in a temperature dependent manner, plays a crucial role in the assay procedure (Dahlberg et al, 1980; Glatz and Veerkamp, 1983b). At $37^{\circ} \mathrm{C}$, Lipidex 1000 was found to remove both non-protein bound and protein associated FA from an aqueous solution, whereas at $0^{\circ} \mathrm{C}$ it only removed non-protein bound FA (Glatz and Veerkamp, 1983a,b). This property made it possible to discriminate between free and protein bound FA in solutions containing fatty acid-binding proteins. The assay was initially developed to identify FABP during purification procedures and to study the FA binding capacities of various dealbuminized cytosol preparations (Glatz et al, 1984). At present, the assay is generally referred to as 'Lipidex 1000 assay' and is frequently used to monitor FA binding by purified fatty acid-binding proteins (FABP) in order to obtain apparent dissociation constants $\left(K_{d}\right)$ and maximum binding $\left(B_{\max }\right)$ values (e.g. Paulussen et al, 1988; Lowe et al, 1987; Kimura et al, 1989).

In the Lipidex 1000 assay, aqueous solutions of long-chain FA in the $\mu$ molar range are commonly used. Because of their amphiphilic character, FA have affinity for both hydrophobic and hydrophillic environments. As a result, FA in an aqueous environment will partially adsorb to the surface of the test-tube containing the FA solution as already mentioned previously (Glatz and Veerkamp, 1983b). Furthermore, at pH 7-9, FA will be present in two phases, a lamellar FA/soap phase and the aqueous phase whereby the former will dominate (Cistola et al, 1988; Brodersen et al, 1989). FA micelles will not be present at this $\mathrm{pH}$ interval (Cistola et al, 1988). Theoretically, the binding of FA to the surface of the reaction vial (e.g. glass or polypropylene) will result in a lower aqueous FA concentration, hence an underestimation of the bound/free (B/F) ratio and thus overestimation of the apparent dissociation constant $\left(\mathrm{K}_{\mathrm{d}}\right)$. Besides $F A$, proteins are also known to adsorb to surfaces (Cantarero et al, 1980; Andrade, 1985) in a time and temperature dependent manner. Possible adsorption of FABP to the surface of the reaction 
vessel in the Lipidex 1000 assay will result in an underestimation of the value for maximum FA binding $\left(\mathrm{B}_{\max }\right)$.

The present study was carried out to determine the effects of adsorption of fatty acids and FABP to the surface of the reaction vessel on $K_{d}$ and $B_{\max }$ values as monitored by the Lipidex 1000 procedure. The effects of the utilization of detergents in the assay were also examined. Two commonly used non-ionic detergents, i.e. Triton X-100 and Tween 20, were included in the assay at various concentrations to minimize FA and FABP adsorption to the surface of the reaction vessel.

\section{MATERIALS AND METHODS}

Purified rat heart FABP was used in all experiments. Purification was carried out using gel filtration and ion-exchange chromatography essentially according to Paulussen et al (1988). The overall yield of the protein was about 5\%. Purity of the protein was confirmed with SDS polyacrylamide gel electrophoresis and isoelectric focusing using Phast System (Pharmacia LKB, Uppsala, Sweden). Amino acid analyses by HPLC (Van Eijck et al, 1988) were carried out for precise FABP quantification. The coefficient of variation of amino acid analyses was in the order of 2\% (Paulussen et al, 1988; Van Eijck et al, 1988). Purified preparations were dialyzed against phosphate buffered saline (PBS), $\mathrm{pH} 7.4$, overnight at $4^{\circ} \mathrm{C}$ and stored at $-20^{\circ} \mathrm{C}$ in polypropylene vials in a final concentration of $27.2 \mu \mathrm{M}$. When stored in this way, no detectable decrease of concentration or FA binding capacity of the samples was observed after 10 months.

$\left[1-{ }^{14} \mathrm{C}\right]$ Oleic acid (specific activity $51.8 \mathrm{Ci} / \mathrm{mol}, 250 \mu \mathrm{Ci}$ in toluene) was purchased from Amersham International (Amersham, UK). The solution was evaporated under vacuum. Thereafter the oleic acid was redissolved in $10 \mathrm{ml}$ absolute ethanol and stored in a final concentration of $0.48 \mathrm{mM}$ at $-20^{\circ} \mathrm{C}$. Lipidex 1000 was obtained from Packard Instrument Company Inc. (Downers Grove, Illinois, USA). Before use, Lipidex was exhaustively freed of methanol and stored as a $50 \%$ ( $/ \mathrm{v}$ ) suspension in $10 \mathrm{mM} \mathrm{K}$-phosphate buffer, $\mathrm{pH} 7.4$, at $4^{\circ} \mathrm{C}$. Goat anti rabbit lgG/horseradish peroxidase was obtained from Nordic (Tilburg, The Netherlands). All other chemicals were obtained from Merck (Darmstadt, FRG).

To measure the recovery of protein after Lipidex 1000 assay, FABP was quantified with an Enzyme Linked Immuno-Sorbent assay. For this, rabbits were immunized with purified rat heart FABP yielding antisera with a titer of 8000 . FABP samples were directly coated onto PVC microtiterplates overnight at $4^{\circ} \mathrm{C}$. After incubation with rabbit anti-rat heart $\mathrm{FABP}$ and subsequently with goat anti-rabbit $\mathrm{lgG}$ /horseradish peroxidase the FABP content was determined by measuring the oxidation rate of o-Phenylene-Diamine in the presence of hydrogen peroxide. The detection limit of the assay amounted to $0.1 \mathrm{ng}$ FABP.

\section{Lipidex 1000 assay}

The assay was performed in a $10 \mathrm{mM}$ Tris- $\mathrm{HCl}$ buffer $(\mathrm{pH} \mathrm{8.0)}$ containing none or various concentrations of detergent as indicated. This buffer was also used to dilute FA and FABP stock solutions. $\left[1-{ }^{14} \mathrm{C}\right]$ Oleic acid dilutions, ranging from 1 to $10 \mu \mathrm{M}$, were freshly prepared from the above mentioned ethanolic stock solution of $0.48 \mathrm{mM}$. Fixed amounts of FABP (136 \pm 3 pmol) were used in each determination.

For the assay, $150 \mu \mathrm{l}$ Tris-HCl buffer ( $\mathrm{pH} 8.0), 50 \mu \mathrm{FABP}$ solution $(2.72 \mu \mathrm{M})$ and 50 $\mu$ I FA solution were mixed in this order in an 1.5-ml Eppendorf polypropylene reaction vial. After incubation for 15 minutes at $37^{\circ} \mathrm{C}$, the vials were centrifuged for a few seconds to remove condense from the lid and subsequently placed on ice. From each vial $50 \mu$ was 
taken and pipetted in a scintillation vial to assess the actual FA concentration in the aqueous solution. To the remaining volume, $50 \mu \mathrm{l}$ of continuously stirred ice-cold Lipidex 1000 suspension was added and mixed 3-4 times on a vortex mixer during a 30 minutes incubation at $0^{\circ} \mathrm{C}$. Finally, the vials were centrifuged ( 2 minutes, $10,000 \mathrm{~g}$ at $4^{\circ} \mathrm{C}$ ) and 100 $\mu \mathrm{l}$ of supernatant was pipetted into scintillation vials to quantify the amount of bound FA. In some experiments an additional $10 \mu \mathrm{l}$ was taken for FABP assessment in the solution using the above described ELISA. Radioactivity was measured with a Beckman LS 3801 scintillation counter (Beckman Instr. Inc., Fullerton, California, USA). Blank values were obtained for each FA dilution by measuring the radioactivity of incubations in which $50 \mu l$ Tris buffer without FABP was added. The measured blank values were subtracted from the FA binding data. Blank values increased when detergent concentration was elevated but never exceeded $3 \%$ of the total amount of radioactive FA added to each vial.

Data obtained were analyzed according to Zivin and Waud (1982) and visualized using Eadie-Hofstee plots in which the slope of the curve represents the apparent dissociation constant $\left(K_{d}\right)$ and the $Y$-axis intercept the maximal FA-binding $\left(B_{\text {max }}\right)$. All values for $F A$ binding are expressed as moles FA bound per mole of FABP.

\section{RESULTS}

Data in Table 3.1. show that in glass, polypropylene and polystyrene vials a substantial amount of FA was lost from the aqueous solution when no detergent was present. In addition, FA loss appeared dependent on the material of which the vials are made. The FA concentration decrease occurred instantaneously independent of the temperature (data not shown). In polypropylene vials, addition of $100 \mu \mathrm{M}$ Triton $X-100$ reduced the loss of FA to less than $20 \%$. Elevation of the Triton $X-100$ concentration to $200 \mu \mathrm{M}$ did not significantly further reduce the FA loss. It should be noted that all Triton $X-100$ concentrations were below its critical micellar concentration $(0.24 \mathrm{mM})$. Utilization of Tween 20 gave comparable results.

\begin{tabular}{llll} 
Test-tube material & Detergent & {$\left[1{ }^{14} \mathrm{C}\right]$ Oleic acid recovery(\%) } \\
\hline Glass & None & & $25 \pm 1$ \\
Polystyrene & None & & $65 \pm 1$ \\
Polypropylene & None & $42 \pm 1$ \\
& Triton X-100 & $100 \mu \mathrm{M}$ & $84 \pm 1^{*}$ \\
& & $150 \mu \mathrm{M}$ & $82 \pm 1^{*}$ \\
& & $200 \mu \mathrm{M}$ & $84 \pm 1^{*}$ \\
& & $54 \mu \mathrm{M}$ & $76 \pm 1^{*}$ \\
\hline
\end{tabular}

Table 3.1: Recovery of $\left[1{ }^{14} \mathrm{C}\right]$ oleic acid in the aqueous medium at various detergent concentrations. Determinations were carried out in a total volume of $250 \mu$ l.Fatty acid concentration varied between 1 and $10 \mu \mathrm{M}$. "Significantly different $(p<0.05)$ from values measured in the absence of detergent (MeantSD, $n=60$ ).

Under our assay conditions FABP was also largely bound to the polypropylene vials. The recovery of FABP in the aqueous solutions amounted to $28 \pm 4 \%$ (mean \pm S.D. for 20 determinations) and was found to be dependent on the incubation time and temperature (data not shown). However, in the presence of detergent (100 $\mu \mathrm{M}$ Triton X-100), protein loss was completely eliminated during performance of the assay (data not shown). Neglect of the 
binding of FA and FABP to the test-tube surface markedly influences the apparent dissociation constant $\left(K_{d}\right)$ and maximal binding $\left(B_{\max }\right)$. This is illustrated for a typical experiment in Figure 3.1, in which experimentally obtained data are presented using the Eadie-Hofstee plot technique (Zivin and Waud, 1982). The advantage of this representation technique is that both $K_{d}$ and $B_{\max }$ values and their error limits are estimated in a direct manner. When FA and FABP losses are not considered (graph 1), the $K_{d}$ is substantially overestimated and the $B_{\max }$ underestimated. A correction made for FA loss alone (graph 2) still leads to erroneous values. Therefore, it is important to eliminate both FA and FABP adsorption to the surface of the test-tube during the Lipidex 1000 assay as much as possible, or to correct appropriate for losses (graph 3).

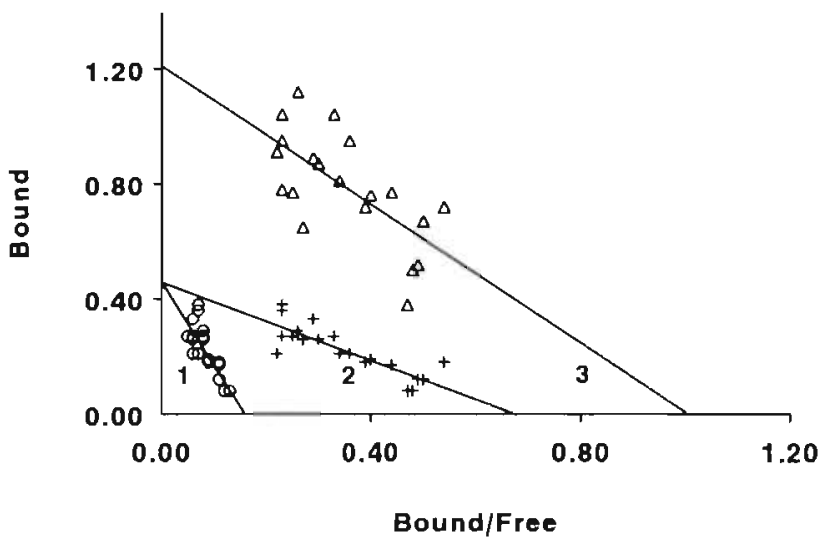

Fig. 3.1. Eadie-Hotstee plot of oleic acid binding by rat heart FABP in the absence of detergent: Effect of the binding of FA and FABP to the polypropylene test-tube. Actual concentrations of FA were measured radiochemically, those of FABP by ELISA. The results of a representative experiment are shown. In graph 1 both FA and FABP losses were assumed to be negligible $\left\langle K_{\mathrm{dd}}=1.60 \pm 0.30\right.$, $\left.B_{\max }=0.46 \pm 0.05, r=0.79\right)$. In graph 2 a correction was made for the loss of $F A$ only $\left(K_{d}=0.37 \pm 0.05\right.$, $\left.B_{\max }=0.46 \pm 0.04, r=0.84\right)$. Graph 3 shows the plot with the actual aqueous concentrations of $F A$ and FABP after the correction of losses due to adsorption to the surface of the testtube. $\left(K_{\mathrm{d}}=0.20 \pm 0.15, \mathrm{~B}_{\max }=1.20 \pm 0.10, r=0.69\right)$.

The influence of the presence of Triton $X-100$ or Tween 20 on the kinetic parameters of oleic acid binding by FABP, calculated on the basis of the actual FA and FABP concentrations is illustrated in Figure 3.2 (data given in Table 3.2). The detergents did influence the apparent $K_{d}$ to some extent but did not significantly affect $B_{\max }$ values. The $K_{d}$ value slightly increased when the detergent concentration was elevated. The affinity of FABP for FA apparently decreases when a detergent is present. The largest increase in $K_{d}$ value was observed when Tween 20 was used in the assay at a concentration of $54 \mu \mathrm{M}$.

\section{DISCUSSION}

The present findings indicate that for the assay of the binding of fatty acids by FABP in aqueous media, adsorption of both FA and FABP to the surface of the test-tube is remarkably high and, therefore, seriously hampers the correct calculation of $K_{d}$ and $B_{\max }$ 
values. The effects of Triton X-100, commonly used in membrane protein purification, and Tween 20, applied in many enzyme linked immunosorbent assays, were investigated. These detergents significantly decreased the loss of FA from the aqueous solution and completely eliminated the loss of FABP. Kinetic parameters calculated from binding studies in the presence of Triton $X-100$ appeared similar to those calculated from studies in which no detergent was used but in which corrections were made for FA and FABP adsorption to the test-tube. Thus, addition of detergent to the medium considerably facilitates the assay of the binding of fatty acids by FABP.
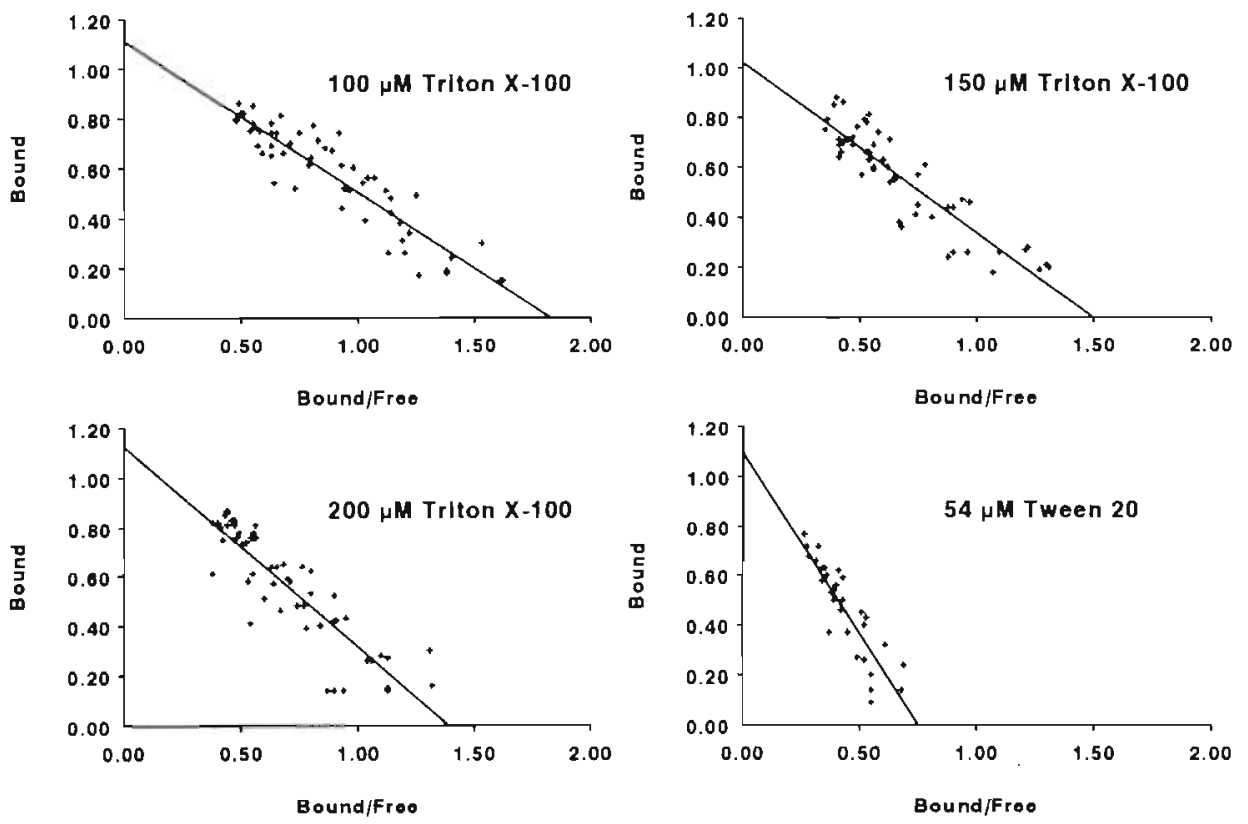

Fig. 3.2. Effect of detergents on the binding of oleic acid by rat heart FABP. Eadie-Hofstee plots are given for determinations in the presence of 100,150 and $200 \mu \mathrm{M}$ Triton X-100 and $54 \mu \mathrm{M}$ Tween 20 , all carried out in polypropylene vials as described in Materials and Methods. The results of representative experiments are shown. Kinetic parameters calculated from the graphs displayed are given in Table 3.2 .

The problem of binding of FA to the surface of the test-tube was already noted in the first description of the Lipidex 1000 assay (Glatz and Veerkamp, 1983b), but the surface adsorption of protein (FABP) was not yet discussed before. Using polyethylene vials and 10minute incubations at $\mathrm{pH} 7.4$, in this previous study the recovery of $\left[1-{ }^{14} \mathrm{C}\right]$ palmitate from the assay mixture was found to be $90-95 \%$ (Glatz and Veerkamp, 1983b), significantly higher than our present observations. Hence, in the absence of detergent, the actual aqueous FA concentration depends to a large extent on the experimental conditions and, possibly, on the type of fatty acid employed.

The presence of a detergent in the Lipidex 1000 assay did influence the apparent $K_{d}$ value (Table 3.2), especially in case of Tween 20 at a relative low concentration. A feasible explanation for this phenomenon can be offered when the molecular structure of Tween 20 is taken into account. According to Sacchettini and co-workers (1989), the free carboxyl 
group of long-chain fatty acids plays a role in the binding of FA by FABP. Because Tween 20 contains a $\mathrm{C} 12$ fatty acid chain with a free carboxyl group, it may bind to FABP in a similar way as FA do. In analog to enzyme kinetics, this phenomenon may be called competitive inhibition resulting in increased $K_{d}$ values. The $B_{\max }$ value, however, will not change because the inhibitory effect of Tween 20 can be eliminated by elevating the concentration of FA. The explanation above given is not applicable to the small increase in apparent $K_{d}$ value observed in the presence of Triton $X-100$, as this detergent lacks a fatty acid group. Possibly, at high concentrations Triton $X-100$ binds to hydrophobic regions on the FABP molecule resulting in a small conformational change of the protein molecule, thereby causing a decrease of the affinity of FABP for FA.

\begin{tabular}{llll}
\hline Detergent & & $K_{d}(\mu \mathrm{M})$ & $B_{\text {max }}(\mathrm{mol} / \mathrm{mol})$ \\
\hline None & & $0.20 \pm 0.15$ & $1.20 \pm 0.10$ \\
Triton $X-100$ & $100 \mu \mathrm{M}$ & $0.33 \pm 0.02$ & $1.11 \pm 0.04$ \\
& $150 \mu \mathrm{M}$ & $0.38 \pm 0.03$ & $1.03 \pm 0.04$ \\
Tween 20 & $200 \mu \mathrm{M}$ & $0.44 \pm 0.02$ & $1.13 \pm 0.04$ \\
\hline
\end{tabular}

Table 3.2. Kinetic parameters for the binding of $\left[1-{ }^{14} \mathrm{C}\right]$ oleic acid by rat heart FABP at various detergent concentrations. Values and error limits of $K_{d}$ and $B_{\max }$ were calculated from 20 (no detergent) or 60 (all other cases) independent fatty acid-binding measurements in polypropylene vials made for each condition (see Figure 3.2. for further details). Parameters were calculated using the corrected FA and FABP concentrations

Despite the fact that $B_{\max }$ values obtained in this study in the absence and presence of detergent all were slightly but significantly higher than $1(\rho<0.05)$, except for the data obtained with $150 \mu \mathrm{M}$ Triton X-100, the linear relationships observed (Figure 3.2) support the notion that only a single FA binding site is present on rat heart FABP (see Bass, 1988 for a review). In an assay with oleic acid-loaded phospholipid (PL) liposomes the $B_{\max }$ for oleic acid has been reported to be 0.7 (Paulussen et al, 1988) and 2 (Offner et al, 1986). However, in these studies an additional surface for FA binding viz. PL bilayers (Rooney et al, 1983) was present which may have affected the maximal FA binding by FABP.

The results of the our study indicate the difficulty of interpretation of previously reported values of $K_{d}$ and $B_{\text {max }}$ as obtained with the Lipidex 1000 assay and may partially explain the large variation of kinetic parameters reported till now (Bass, 1988). To our knowledge, adequate corrections for surface adsorption of ligands and proteins have not been made in any of these studies. Generally, because the concentration of non-protein bound FA was always presumed not to decrease (at least the reverse was not indicated by the authors) the $B / F$ ratio will have been underestimated resulting in an overestimation of the $K_{d}$ values calculated.

In conclusion, application of the Lipidex 1000 assay to obtain kinetic parameters of FA binding by proteins requires the measurement after incubation of the actual concentrations of FA and protein. The use of labeled FA ensures an easy and accurate determination of their total aqueous concentration, but protein measurements are less accurate and rather laborious as their low concentrations require immunochemical techniques. Thus, for a convenient and yet significant performance of the assay, the addition of detergent to the assay medium is indicated as it will prevent FABP adsorption and limit FA adsorption to the surface of the test-tube. It is recommended to include Triton $X-100$ at a final concentration 
of $100 \mu \mathrm{M}$ in the assay. Apparent $K_{d}$ values obtained in the presence of Triton $\mathrm{X}-100$ will probably be slightly higher than the true values, but binding stoichiometry can be accurately assessed.

\section{ACKNOWLEDGEMENT}

This work was supported by the Netherlands Heart Foundation grant no. 88.073.

\section{REFERENCES}

Andrade JD. 1985. Surface and interfacial aspects of biomedical polymers, Vol 2: Protein adsorption (Ed. J.D. Andrade), pp 1-80, Plenum Press, New York, USA.

Bass NM. 1988. The cellular fatty acid binding proteins: Aspects of structure, regulation and function. Int Rev Cytology 111, 143-184.

Brodersen R, Skriver E, Pedersen AO. 1989. Serum albumin binding of palmitate and stearate. Eur J Biochem 182, 19-25.

Cantarero LA, Butler JE, Osborne JW. 1980. The adsorptive characteristics of proteins for polystyrene and their significance in solid-phase immunoassays. Anal Biochem 105, 375-382.

Cistola DP. Hamilton JA, Jackson D, Small DM. 1988. Ionization and phase behaviour of fatty acids in water: Application of the Gibbs phase rule. Biochemistry 27, 1881-1888.

Dahlberg E, Snochowski M, Gustafsson J-A. 1980. Removal of hydrophobic compounds from biological fluids by a simple method. Anal Biochem 106, 380-388.

Glatz JFC, Veerkamp JH. 1983a. A radiochemical procedure for the assay of fatty acid binding by proteins. Anal Biochem 132, 89-95.

Glatz JFC, Veerkamp JH. 1983b. Removal of fatty acids from serum albumin by Lipidex 1000 chromatography. J Biochem Biophys Meth 8, 57-61.

Glatz JFC, Baerwaldt CCF, Veerkamp JH, Kempen HJM. 1984. Diurnal variation of cytosolic fatty acid-binding protein content and of palmitate oxidation in rat liver and heart. J Biol Chem 259, 4295-4300.

Kimura H, Hitomi M, Odani S, Koide T, Arakawa M, Ono T. 1989. Rat heart fatty acid-binding protein. Biochem J 260, 303-306.

Lowe JB, Sacchettini JC, Laposata M, McQuillan JJ, Gordon Jl. 1987. Expression of rat intestinal fatty acidbinding protein in E. Coli. J Biol Chem 262, 5931-5937.

Offner GD, Troxler RF, Brecher P. 1986. Characterization of a fatty acid-binding protein from rat heart. J Biol Chem 261, 5584-5589.

Paulussen RJA, van der Logt CPE, Veerkamp JH. 1988. Characterization and binding properties of fatty acidbinding proteins from human, pig and rat heart. Arch Biochem Biophys 264, 533-545.

Rooney EK, East JM, Jones OT, McWhirter J, Simmonds AC, Lee AG. 1983. Interaction of fatty acids with lipid bilayers. Biochim Biophys Acta 728, 159-170.

Sacchettini JC, Gordon JI, Banaszak LJ. 1989. Crystal structure of rat intestinal fatty acid-binding protein. J Mol Biol 208, 327-339.

Van Eljk HMH, van der Heijden $\mathrm{MAH}$, van Berlo $\mathrm{CLH}$, Soeters PB. 1988. Fully automated liquidchromatographic determination of amino acids. Clin Chem 34, 2510-2513.

Zlvin JA, Waud DR. 1982. How to analyze binding, enzyme and uptake data: The simplest case, a single phase. Life Sciences 30, 1407-1422. 
CHAPTER 4

\section{A SANDWICH ENZYME LINKED IMMUNO-SORBENT ASSAY FOR THE DETERMINATION OF RAT HEART FATTY ACID-BINDING PROTEIN}

Michaël M. Vork, Jan F.C. Glatz, Don A.M. Surtel, Huub J.M Knubben and Ger J. Van der Vusse.

Biochim Biophys Acta 1075, 199-205, 1991. (reprinted with permission) 


\section{SUMMARY}

An Enzyme Linked Immuno-Sorbent Assay (ELISA) of the sandwich type for the determination of heart-type fatty acid-binding protein (FABP) was developed, making use of the streptavidin-biotin system. The assay turned out to be virtually disturbance insensitive and showed a detection limit for FABP of $0.2 \mu \mathrm{g} / \mathrm{l}$ with an intra- and inter-assay variation of $5 \%$ and $14 \%$, respectively. The FABP content of adult rat heart muscle was found to be $0.740 \pm 0.034 \mathrm{mg} / \mathrm{g}$ wet weight (Mean $\pm S E M, n=12$ ). The FABP content of a number of skeletal muscles varied from 0.013 to $0.303 \mathrm{mg} / \mathrm{g}$ wet weight and was related to the content of type I muscle fibres of these tissues, suggesting a role for FABP in intracellular fatty acid metabolism. The assay was further applied to study the release of FABP from isolated rat heart during normoxic Langendorff perfusion, as compared to that of lactate dehydrogenase $(\mathrm{LDH})$, into fluid derived from the right ventricular cavity $\left(Q_{n}\right)$ and that from the interstitial space $\left(Q_{i}\right)$. Total release of FABP per 15 minutes amounted to $0.015 \pm 0.010 \%$ but that of $\mathrm{LDH}$ to $0.080 \pm 0.040 \%$ of their total tissue content. Furthermore, for both FABP and LDH $80 \%$ was released into $Q_{i}$, which only accounted for $1-2 \%$ of total flow. These findings suggest that during normoxic perfusion of rat heart FABP and LDH are released from different cellular compartments and that the bulk amount of released intracellular proteins is transported via the lymph instead of directly released into the bloodstream.

\section{INTRODUCTION}

Cytoplasmic fatty acid-binding proteins (FABP) are a family of $14-15 \mathrm{kDa}$ proteins present in a variety of organs (Bass, 1988; Glatz and Van der Vusse, 1990; Matarese et al, 1990, Veerkamp et al, 1991). These abundant FABPs are thought to be involved in the regulation of intracellular long-chain fatty acid metabolism, although their precise mechanism of action remains to be elucidated (Glatz and Van der Vusse, 1989). Recently it has been suggested that the release of the heart type FABP from myocardium is a reliable marker to quantify damage inflicted upon the heart (Glatz et al, 1988). To precisely quantify the amounts of FABP released from the heart or its residual content in damaged cardiac tissue, a reliable and sensitive analytical method is required. In addition, this technique should be insensitive to other proteins present in the biological preparations under study. Therefore, the antibody capture Enzyme Linked ImmunoSorbent Assay (ELISA) described by Paulussen et al (1989) is not suitable since in this assay the antigen is directly coated onto the surface of a microtiterplate. Other proteins present in the sample are then likely to compete for binding places on the surface (Andrade, 1985). Alternatively, a competitive ELISA, such as described by Crisman et al (1987) and Knowlton and colleagues (1989), lacks sensitivity. A sandwich ELISA, in which antigen is bound by immobilized IgG and quantified with a second antibody-enzyme conjugate, as described by Börchers et al (1989), appears the appropriate choice because of the high sensitivity and the relatively disturbance insensitivity. To further improve this method, we introduced a biotinylated second antibody instead of an IgG-enzyme conjugate in the assay. Biotin can be detected either by subsequent addition of (strept)avidin and biotinylated enzyme as described by Guesdon et al (1979) or by addition of a preformed complex of these compounds as described by Hsu et al $(1981 a, b)$.

The aim of the present study was to develop a sensitive, virtually disturbance-free assay for the quantification of FABP using the streptavidin-biotin system. The assay was then applied to measure the release of FABP from normoxically Langendorff perfused rat 
hearts. This release was compared to that of lactate dehydrogenase (LDH), because both proteins are thought to be present in the same intracellular compartment. Eventual differences in the release of both proteins might indicate that release is dependent on molecular weight of the proteins (130 kDa for $\mathrm{LDH}$ and $15 \mathrm{kDa}$ for $\mathrm{FABP}$ ), or other physicochemical properties.

In addition, FABP was assessed in both the heart and various skeletal muscles from the adult rat, since the FABP from skeletal muscle was recently reported to be identical to heart type FABP (Veerkamp et al, 1990; Peeters et al, 1991). It was found that the use of the biotin-(strept)avidin system in the sandwich ELISA resulted in a quantitative assay for FABP applicable to effluents from Langendorff perfused rat hearts and tissue homogenates with a detection limit below $0.2 \mu \mathrm{g} / \mathrm{l}$ or $10 \mathrm{pg}$ FABP absolute.

\section{MATERIALS AND METHODS}

\section{Materials}

Protein-A Sepharose and CNBr-activated Sepharose 4B were obtained from Pharmacia (Uppsala, Sweden). Streptavidin, horse-radish peroxidase (HRP), N-hydroxysuccinimide biotin (BNHS), bovine serum albumin (BSA) and ortho-Phenylene-Diamine free base (oPD) were purchased from Sigma (St. Louis, MO, USA). oPD was acidified with $\mathrm{HCl} 0.1 \mathrm{M}(1: 2$, $\mathrm{mol} / \mathrm{mol}$ ) and, after freezing in liquid $\mathrm{N}_{2}$, freeze dried. The $\mathrm{HCl}$ salt of oPD appeared to be a more appropriate substrate for HRP than the free base (data not shown). Tween 20 , glycine, imidazole and glycerol were purchased from Merck (Darmstadt, FRG). Goat-antirabbit lgG/HRP complex (GARPO) was purchased from Nordic (Tilburg. The Netherlands). Falcon PVC 96 wells microtiterplates from Becton Dickinson (Oxnard, CA, USA) were used in all experiments. All other chemicals used were of analytical grade. Streptavidin was stored in phosphate buffered saline (PBS) (10 mM phosphate, $154 \mathrm{mM} \mathrm{NaCl}), \mathrm{pH} 7.4$, containing $30 \%$ glycerol at $-20^{\circ} \mathrm{C}$ in a final concentration of $14 \mu \mathrm{M}$.

\section{Isolation of FABP}

Isolation of FABP from rat heart was performed essentially according to the isolation procedure for human heart FABP as described by Van Nieuwenhoven et al (1991) which turned out to be applicable for rat FABP as well with a minor modification in the ionexchange step. Van Nieuwenhoven et al (1991) eluted human FABP from the ion-exchange medium with a $300 \mathrm{ml}$ linear $\mathrm{NaCl}$ gradient from $0-20 \mathrm{mM}$ in $5 \mathrm{mM}$ imidazole buffer, $\mathrm{pH} 7.0$, whereas rat FABP was eluted with an initial $150 \mathrm{ml} \mathrm{NaCl}$ gradient from $0.15 \mathrm{mM}$ followed by a $500 \mathrm{ml} \mathrm{NaCl}$ gradient from $15-30 \mathrm{mM}$ in $10 \mathrm{mM}$ imidazole buffer, $\mathrm{pH} 7.0$. In a typical purification procedure the overall yield of pure FABP amounted to $0.3-0.4 \mathrm{mg} / \mathrm{g}$ tissue i.e. $50 \%$ of total tissue content.

\section{Production, purification, biotinylation and storage of IgG.}

Rabbits were immunized each with $250 \mu \mathrm{g}$ purified FABP in complete Freunds adjuvant, boosted after six weeks with an additional $250 \mu \mathrm{g}$ FABP in incomplete Freunds adjuvant and bleeded two weeks after boosting. Serial dilutions of the antisera were added to a microtiterplate, previously coated with $10 \mathrm{ng}$ FABP and subsequently detected with GARPO. The titer of the antisera was defined as the antiserum dilution at which the measured extinction amounted to $50 \%$ of the maximal extinction and turned out to be 8000 . 
To separate lgG from other proteins, antisera were applied onto a protein-A Sepharose column. IgG was subsequently eluted with $0.1 \mathrm{M}$ glycine buffer, $\mathrm{pH}$ 2.8. After dialysis against PBS, the IgG preparation was applied onto a Sepharose column to which FABP was covalently coupled according to the manufacturers instructions (Affinity Chromatography, principles and methods; Pharmacia, Sweden). Elution with $0.1 \mathrm{M}$ glycine buffer $\mathrm{pH} 2.8$ yielded a polyclonal anti FABP preparation. An aliquot of this polyclonal preparation was biotinylated according to Harlow and Lane (1988) yielding b-lgG. b-lgG was stored in PBS containing $30 \%$ glycerol and $0.03 \%$ azide at $4{ }^{\circ} \mathrm{C}$.

\section{Biotinylation and storage of HRP}

Biotinylation of HRP was performed in a similar way as for $\mathrm{lgG}$, except that BNHS was added at a concentration of $180 \mu \mathrm{g} / \mathrm{mg}$ protein instead of $100 \mu \mathrm{g} / \mathrm{mg}$ protein. No significant loss of HRP was assumed during biotinylation and dialysis because a HRP solution with high concentration was used $(5.36 \mathrm{mg} / \mathrm{ml})$. b-HRP was stored in PBS containing $30 \%$ glycerol at a concentration of $134 \mu \mathrm{M}$ at $-20^{\circ} \mathrm{C}$. Storage at these conditions did not show any inactivation during at least six months whereas storage at higher temperatures $\left(4^{\circ} \mathrm{C}\right)$ resulted in a gradual decrease of enzyme activity irrespective of glycerol concentration.

\section{Performance of sandwich ELISA}

PVC plates were coated with $50 \mu \mathrm{l} 0.1 \mathrm{M}$ carbonate buffer ( $\mathrm{pH} 9.6$ ) containing $100 \mathrm{ng}$ anti-FABP-lgG at $37^{\circ} \mathrm{C}$ for 2 hours. Thereafter the plates were washed five times with PBT (PBS $+0.1 \% \mathrm{BSA}+0.05 \%$ Tween $20, \mathrm{pH} 7.4$ ). All other steps were performed at room temperature in $50 \mu \mathrm{PBT}$. FABP, either in standards or biological samples, was allowed to bind to immobilized IgG for 90 minutes. Blank values were assessed by incubating $50 \mu \mathrm{l}$ PBT onto IgG coated wells. All samples, standards and blanks were assessed in triplicate. After five fold washing, $200 \mathrm{ng} \mathrm{b-IgG} \mathrm{was} \mathrm{added} \mathrm{and} \mathrm{incubated} \mathrm{for} 90$ minutes. Thirty minutes prior to use, streptavidin and b-HRP were mixed in PBT at various ratios in order to assess the optimal ratio, with a constant streptavidin concentration of $12 \mathrm{nM}$. After washing, $50 \mu$ lof the streptavidin/b-HRP solution was added to the plates and incubated for 30 minutes. Excess streptavidin/b-HRP complex was removed by multiple washing with PBT and $100 \mu \mathrm{l} 0.1 \mathrm{M}$ citrate buffer, $\mathrm{pH} 5.0$ containing $20 \mathrm{mM}$ oPD and $6 \mathrm{mM} \mathrm{H}_{2} \mathrm{O}_{2}$, unless indicated otherwise, was added to each well and incubated for 10-20 minutes. Finally, the enzyme reaction was terminated with $50 \mu / 4 \mathrm{M} \mathrm{H}_{2} \mathrm{SO}_{4}$ and optical density measured with a Titertek Multiskan MK II at $492 \mathrm{~nm}$.

\section{Enzyme kinetics of b-HRP}

To obtain maximum sensitivity during the developing step of the ELISA, the optimum oPD concentration was assessed by measuring enzyme activity at various OPD concentrations with a fixed amount of b-HRP, either free in solution or immobilized during ELISA performance. The hydrogen peroxide concentration was always kept at $6 \mathrm{mM}$. Substrate solutions were added to microtiterplates. Kinetic extinction measurements at 450 $\mathrm{nm}$ were performed every minute. At this wavelength the extinction coefficient turned out to be maximum for the unacidified reaction product (2,2-diamino-azobenzol). Initial enzyme velocities (v) were calculated from the slope of the reaction curve and were plotted in the Eadie-Hofstee format ( $v /[s]$ versus $v$, [s] being substrate concentration). From these curves $\mathrm{K}_{\mathrm{m}}$ values were calculated. 


\section{Rat heart isolation, preparation and perfusion}

Rat hearts were perfused according to De Deckere and Ten Hoor (1977) which allowed separate collection of right ventricular effluent $\left(Q_{n}\right)$ and interstitial effluent $\left(Q_{i}\right)$, the latter dripping from the apex at a rate of $1-2 \%$ of total flow. Preparation time amounted to 20-25 minutes after which the heart was allowed to stabilize for 30 minutes. Thereafter, effluents were collected at 15 minute intervals and, after weighing, immediately frozen in liquid nitrogen in the presence of $1-2 \%$ BSA for future analysis of FABP and of lactate dehydrogenase (LDH). The latter was measured according to Bergmeyer and Bernt (1974) on a Cobas Bio analyzer (Hoffman-La Roche, Basel, Switzerland) at $25^{\circ} \mathrm{C}$. BSA was added to stabilize the cardiac proteins in the effluent during frozen storage (Snoeckx, 1987).

\section{FABP in muscle tissues}

With use of the described ELISA, the absolute tissue contents of FABP in the heart and several skeletal muscles of the rat were assessed and compared with the content of slow-twitch muscle fibres (type 1), which mainly oxidize fatty acids (Lehninger, 1975). Skeletal muscles were rapidly removed from diethylether anaesthetized male adult Lewis rats and homogenized in ice-cold PBS (5\% w/v) after which the homogenates were centrifuged at $4^{\circ} \mathrm{C}$ at $15,000 \mathrm{xg}$ for 15 minutes to remove cell debris. To some aliquots of the tissue homogenates a known amount of pure FABP was added in order to assess its overall recovery in the assay. The FABP contents of these homogenates were measured at several dilutions and the recovery was calculated from the values measured in the presence and absence of additional FABP.

\section{Statistical data analysis}

All results are expressed as the mean \pm SEM unless indicated otherwise. Student's $f$ test was used to establish the significance of calculated differences.

\section{RESULTS AND DISCUSSION}

\section{Enzyme kinetics of b-HRP}

HRP activity decreased during incubation with oPD and $\mathrm{H}_{2} \mathrm{O}_{2}$, as already observed by Porstmann et al (1981). Furthermore, the reaction showed a 3-4 minute lag phase when bHRP was immobilized in an ELISA whereas this lag phase was not observed with unbound b-HRP (Figure 4.1. left panel).

To construct Eadie-Hofstee plots for the bound and free situation, the extinction increase at $450 \mathrm{~nm}$ at several oPD concentrations was measured by calculating the tangent of the reaction curves at $t=4$ minutes. To compare the bound and free situation, in each case the data were normalized to a maximum enzyme velocity value of 100 . Figure 4.1, right panel shows that the enzyme kinetics are influenced by the state of the enzyme (immobilized or free). The apparent $K_{m}$ values at room temperature were calculated according to the method of Zivin and Waud (1982) and amounted to $5.1 \pm 0.3 \mathrm{mM}$ oPD for the free and to $7.9 \pm 0.9 \mathrm{mM}$ oPD for the immobilized situation $(p<0.02)$. A possible explanation for this significant difference is that the chance that an enzyme molecule and a substrate molecule meet is decreased when the enzyme can not diffuse freely through the solution. At high concentrations ([oPD]>25 mM) substrate inhibition occurred (data not 
shown). From these measurements we decided to use oPD in a concentration of $20 \mathrm{mM}$ in all further experiments, appreciably higher than an oPD concentrations of $10 \mathrm{mM}$ used by Börchers et al (1989) and of $2.2 \mathrm{mM}$ used by Paulussen et al (1989).
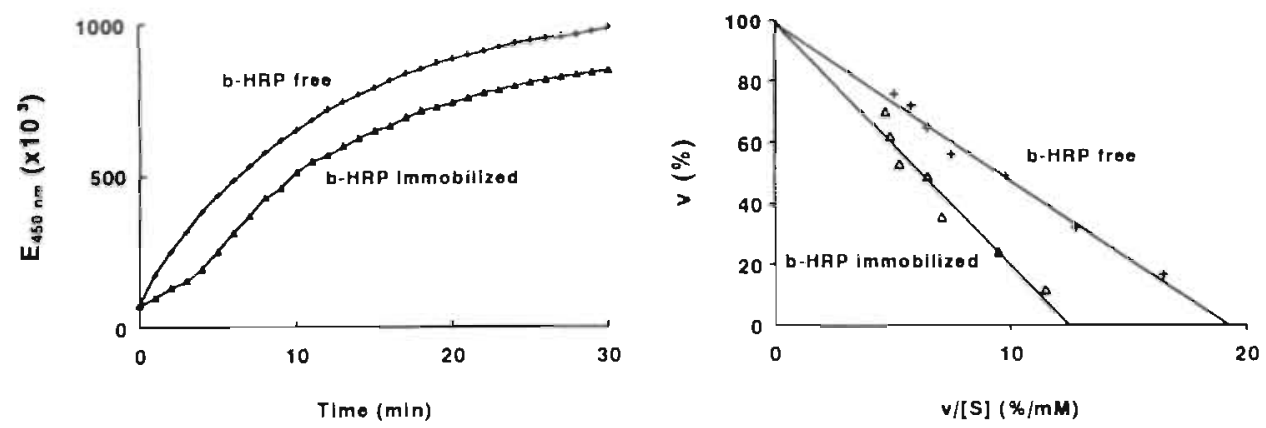

Fig. 4.1. Left panel: Biotinylated horse-radish peroxidase (b-HRP) activity in time. For both situations an activity decrease in time was observed. Note the lag phase observed with immobilized b-HRP. Right panel: Affinity of biotinylated horse-radish peroxidase for OPD at fixed hydrogen peroxide concentration $(6 \mathrm{mM})$ either in immobilized $(\Delta)$ or free $(+)$ state. Curves are drawn in the EadieHolstee format in which the enzyme velocity, normalized to $100 \%$ maximum velocity, is on the $\mathrm{Y}$-axis whereas the quotient of enzyme velocity and substrate concentration in $\mathrm{mM}$ is on the $\mathrm{X}$ axis. See text for further details.

\section{Enzyme linked immuno-sorbent assay}

In a sandwich ELISA for the quantification of bovine FABP, described by Börchers et al (1989), detector antibodies chemically conjugated with horse-radish peroxidase were used. The detection limit of their assay amounted $50 \mathrm{pg}$ FABP. A disadvantage of the use of an IgG-enzyme conjugate is that the efficiency of the conjugation procedure determines the final sensitivity of the assay and can hardly be influenced afterwards. Furthermore, conjugation of an enzyme with IgG can cause inactivation of IgG, either by direct binding to the antigen binding site or by steric hindrance. Biotinylation of $\mathrm{IgG}$ is a much milder procedure and probably causes much less lgG inactivation because the biotin molecule is very small compared to the IgG molecule. Moreover, the sensitivity of the assay is not only determined by the amount of biotin bound to IgG but can be manipulated by using variable amounts of streptavidin and b-HRP. Ever since Guesdon et al (1979) introduced the biotin(strept)avidin system in an immuno-assay, the system has been increasingly used for the determination of a large variety of antigens (Bayer and Wilchek, 1980; Wilchek and Bayer, 1988). Because we were interested in the release of cytoplasmic proteins from normoxically perfused rat hearts, our goal was to develop an assay with an extremely low detection limit.

In order to reach a sensitivity as high as possible we mixed varying amounts of streptavidin and b-HRP and allowed it to form large complexes for 30 minutes. The use of avidin instead of streptavidin resulted in high aspecific binding of the preformed complex to the PVC microtiterplates used, thus causing high blank values (data not shown). This aspecific sticking of avidin is most likely caused by its basic nature and/or by the presence of sugar residues on the molecule, properties which streptavidin both lacks (Wilchek and Bayer, 1988).

The streptavidin concentration was routineously kept constant at $12 \mathrm{nM}$ whereas the b-HRP was varied. Maximum sensitivity was achieved at a molar ratio of streptavidin/b-HRP 
of $1 / 5$. However, at this ratio the blank value amounted 0.24 after 10 minutes colour development. Therefore, we chose a ratio streptavidin/b-HRP of $1 / 3$ to $1 / 4$ which still resulted in a sufficient sensitivity without a large blank increase. An increase in the concentration of streptavidin did not further increase the sensitivity of the assay.

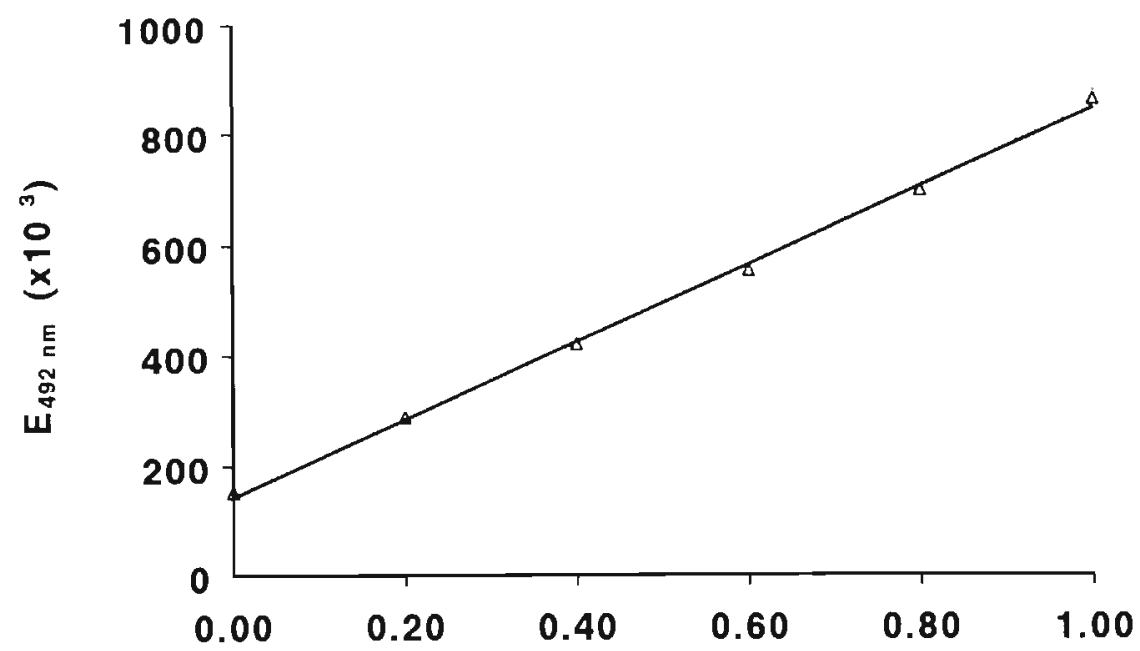

\section{$\operatorname{FABP}(\mu g / l)$}

Fig. 4.2. Calibration curve of the sandwich ELISA for FABP. Each calibration point was assessed in 8 fold. Plates were incubated with substrate solution for 20 minutes as described in the Materials and Methods section. After acidification extinctions were measured at $492 \mathrm{~nm}$.

The detection limit was defined as the amount of FABP corresponding with an extinction of blank+2xSD (of the blank). This value was found to be $0.2 \mu \mathrm{g} \mathrm{FABP/l}$ (10 pg or $0.67 \mathrm{fmol}$ absolute) at a streptavidin/b-HRP ratio of 1/3. In Figure 4.2. an example of a typical calibration curve is shown.

The recovery of FABP, added to a tissue homogenate, turned out to be $97 \pm 6 \%$. This value ensured us that the binding characteristics of FABP to the catcher-IgG was independent of the presence of other proteins in the sample.

\section{Rat heart perfusion}

Figure 4.3. shows the release of FABP and LDH from isolated rat hearts during normoxic Langendorff perfusion. The total amounts released were $109 \pm 63 \mathrm{ng}$ FABP/15 minutes and $244 \pm 102 \mathrm{mU} L D H / 15$ minutes $(n=36)$. The relative amounts of LDH and FABP released in $Q_{i}$ were $79 \pm 20 \%$ and $77 \pm 9 \%$, respectively. The release patterns for the two proteins were found to be similar. The finding that approximately $80 \%$ of intracellular proteins, released from the heart during normoxic perfusion, is present in the interstitial effluent $\left(Q_{i}\right)$ indicates that in situ the majority of proteins released from the heart is transported via the lymph before entering the bloodstream. This percentage seems to be independent of the molecular weights (15 kDa for FABP and $130 \mathrm{kDa}$ for LDH) of the 
proteins released from the heart.

In most $Q_{r v}$ samples, $\mathrm{LDH}$ activity was only slightly higher than the detection limit for this assay $(0.5 \mathrm{U} / \mathrm{l})$ due to the large volume of $Q_{N}(98-99 \%$ of total flow). FABP, however, was readily measurable in all samples assayed. When the tissue contents of LDH and FABP are considered, i.e. $316 \pm 13 \mathrm{U} / \mathrm{g}$ wet weight and $740 \pm 120 \mu \mathrm{g} / \mathrm{g}$ wet weight, respectively $(n=12)$, the $Q_{i}+Q_{n}$ release per 15 minutes of $L D H$ amounted to $0.080 \pm 0.040 \%$ of total tissue content whereas that of FABP was only $0.015 \pm 0.010 \%$ of total tissue content. A possible explanation for this significant difference $(p<0.02)$ is that during normoxic perfusion, FABP is released from cardiomyocytes only whereas LDH is released from both cardiomyocytes and endothelial cells. Earlier we found that the latter cell type contains only $0.2 \%$ of the FABP content of cardiomyocytes (Linssen et al, 1990). Another explanation for this finding may be that within the cardiomyocyte FABP and LDH are not entirely present in the same compartments, or that FABP is partly non-covalently bound to (intra)cellular membranes as was reported for liver FABP by Bordewick et al (1989). Börchers et al (1989) and Fournier and Rahim (1985) both showed that FABP is partly associated with myofibrils and mitochondria. However, the limited amount of FABP associated with these intracellular structures probably can not explain the discrepancy between FABP and LDH release.
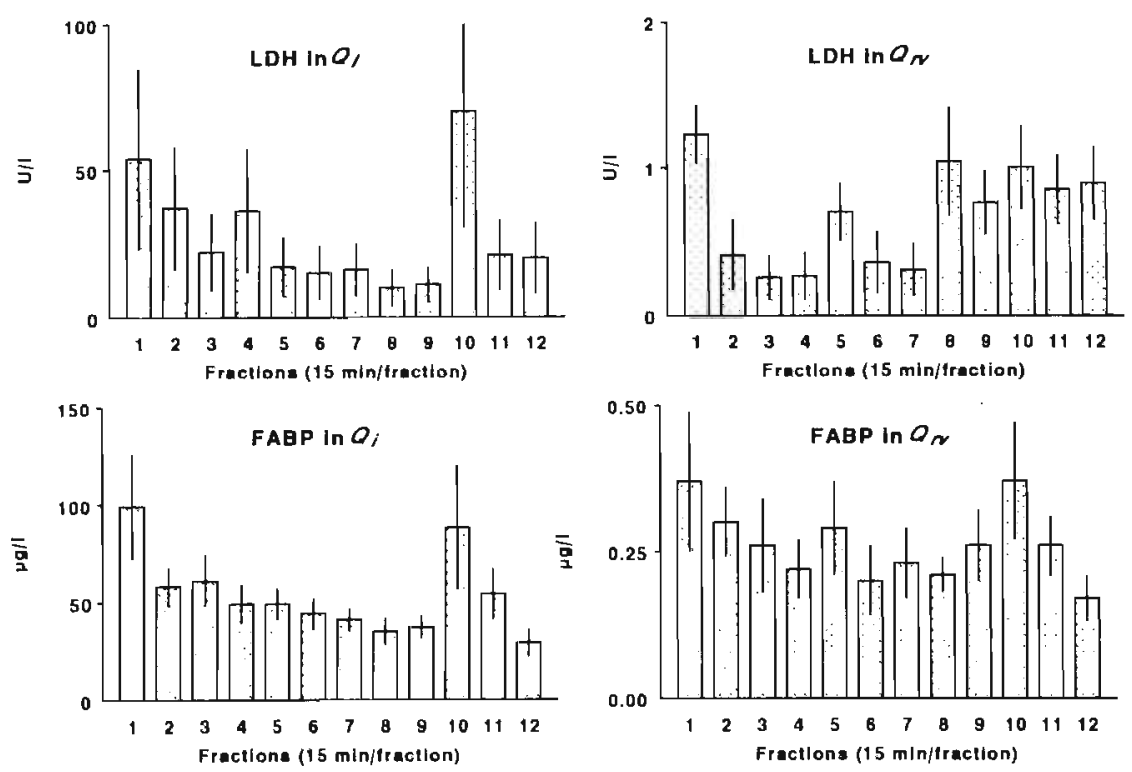

Fig. 4.3. Release of $L D H$ and FABP from isolated Langendorff perfused rat hearts with separate collection of right ventricular $\left(Q_{n}\right)$ and interstitial effluent $\left(Q_{i}\right)(n=3)$. Note the differences in concentration in $Q_{i}$ and $Q_{n}$ for both proteins.

\section{FABP content in the heart and several other muscle tissues}

The FABP content in rat heart was found to be $0.740 \pm 0.034 \mathrm{mg} / \mathrm{g}$ wet weight. This value is appreciably lower than concentrations of FABP reported by other authors (Paulussen et al, 1989; Crisman et al, 1987; Knowlton et al, 1989; Bass and Manning, 1986) 
i.e. approximately $1.5 \mathrm{mg} / \mathrm{g}$ wet weight. Because of the measured recovery of $97 \pm 6 \%$ in the present study (see above) we conclude that concentrations earlier reported have been largely overestimated. A probable cause of this difference might be the use of a less accurate and/or less specific assay for FABP.

\begin{tabular}{lcc}
\hline Muscle & $\begin{array}{c}\text { Fibre type I } \\
(\%)\end{array}$ & $\begin{array}{c}\text { FABP } \\
(\mathrm{mg} / \mathrm{g})\end{array}$ \\
\hline m. quadriceps: superficial & $0^{(\mathrm{a})}$ & $0.013 \pm 0.001$ \\
m. flexor digitorum brevis & $7^{(\mathrm{b})}$ & $0.015 \pm 0.000$ \\
m. gastrocnemius & $5^{(\mathrm{c})}$ & $0.030 \pm 0.003$ \\
m. exterior digitorum longus & $3^{(c)}$ & $0.053 \pm 0.001$ \\
m. diaphragma & $60^{(\mathrm{d})}$ & $0.246 \pm 0.001$ \\
m. quadriceps: deep & $70^{(\mathrm{a})}$ & $0.222 \pm 0.003$ \\
m. soleus & $84^{(\mathrm{b})}$ & $0.303 \pm 0.014$ \\
heart & & $0.740 \pm 0.034$
\end{tabular}

Table 4.1. Relation between muscle fibre type and FABP content in several rat muscles $(n=3)$. Data concerning muscle fibre type I content were taken from ${ }^{(a)}$ Baldwin et al, 1972; ${ }^{(0)}$ Koerker et al, 1990; ${ }^{(c)}$ Ariano et al, 1973; ${ }^{\text {(d) }}$ Close, 1972.

The FABP content was determined in a variety of rat skeletal muscles with the use of the described ELISA. The results are shown in Table 4.1. The lowest content was found in the superficial $\mathrm{m}$. quadriceps $(0.013 \mathrm{mg} / \mathrm{g}$ wet weight) whereas the highest level was found in the $\mathrm{m}$. soleus $(0.303 \mathrm{mg} / \mathrm{g}$ wet weight). Since recent studies conducted by Peeters et al (1991) showed that heart and skeletal muscle FABP are identical and that skeletal muscle only contains one type of FABP, the present findings represent the vital content of FABP in skeletal muscles. Literature data concerning the percentage of oxidative type I fibres in the skeletal muscles (Baldwin et al, 1972; Koerker et al, 1990; Ariano et al, 1973; Close, 1972) are included as well in Table 4.1. Interestingly, a positive relationship between the level of FABP and the percentage of fibre type I can be observed. Since fatty acids are important substrates in these oxidative slow muscle fibres and FABP is thought to be involved in the intracellular transport of fatty acids, it is tempting to state that the quantitative relationship between FABP and type I muscle fibre content in skeletal muscle tissue suggests a crucial role of $\mathrm{FABP}$ in the overall rate of fatty acid oxidation.

\section{ACKNOWLEDGEMENT}

The authors wish to express their gratitude to Prof. Dr. F. Spener and Dr. T. Börchers of the University of Münster, Germany, for their hospitality and stimulating discussions concerning the development of the described immuno-assay. This work was supported by the Netherlands Heart Foundation, grant number 88.073.

\section{REFERENCES}

Andrade JD. 1985. Surface and interfacial aspects of biomedical polymers, vol 2: Protein adsorption (Ed JD Andrade), pp. 1-80. Plenum Press, New York, USA.

Ariano MA, Armstrong RB, Edgenton VR. 1973. Hindlimb muscle fibre populations of five mammals. J Histochem Cytochem 21, 51-55. 
Baldwin KM, Klinkerfuss GH, Terjung RL, Molé PA, Holloszy JO. 1972. Respiratory capacity of white, red and intermediate muscle: adaptive response to exercise. Am J Physiol 222, 373-378.

Bass NM, Manning JA. 1986. Tissue expression of three structurally different fatty acid-binding proteins from rat heart muscle, liver and intestine. Biochem Biophys Res Commun 137, 929-935.

Bass NM. 1988. The cellular fatty acid-binding proteins: Aspects of structure, regulation and function. Int Rev Cytology 111, 143-184.

Bayer EA, Wilchek M. 1980. The use of the avidin-biotin complex as a tool in molecular biology. Meth Biochem Anal 26, 1.45.

Bergmeyer HU, Bernt E. 1974. Methods of enzymatic analysis. Vol. 2 (Ed Bergmeyer HU), pp. 574-579. Weinheim Verlag Chemie GimbH, FRG.

Börchers T, Underberg C, Rüdel H, Robenek H, Spener F. 1989. Subcellular distribution of cardiac fatty acidbinding protein in bovine heart muscle and quantification with an enzyme-linked immunosorbent assay. Biochim Biophys Acta 1002, 54-61.

Bordewick U, Heese M, Börchers T, Robenek H, Spener F. 1989. Compartmentation of hepatic fatty acidbinding protein in liver cells and its effects on mitochondrial phosphatidic acid biosynthesis. Biol Chem HoppeSeyler 370, 229-238.

Close RI. 1972. Dynamic properties of mammalian skeletal muscles. Physiol Rev 52, 129-197.

Crisman TS, Claffey KP, Saouaf R, Hanspal J, Brecher P. 1987. Measurement of rat heart fatty acid-binding protein by ELISA. Tissue distribution, developmental changes and subcellular distribution. J Mol Cell Cardiol 19, 423-431.

De Deckere EAM, Ten Hoor P. 1977. A modified Langendorff technique for metabolic investigations. Pflügers Arch 370, 103-105.

Fournier NC, Rahim M. 1985. Control of energy production in the heart. A new function for fatty acid-binding protein. Biochemistry 24, 2387-2396.

Glatz JFC, Van Bilsen M. Paulussen RJA, Veerkamp JH, Van der Vusse GJ, Reneman RS. 1988. Release of fatty acid-binding protein from isolated rat heart subjected to ischemia or to the calcium paradox. Biochim Biophys Acta 961, 148-152.

Glatz JFC, Van der Vusse GJ. 1989. Intracellular transport of lipids. Mol Cell Biochem 88, 37-44.

Glatz JFC, Van der Vusse GJ. 1990. Cellular fatty accid-binding proteins: current concepts and future directions. Mol Cell Biochem 98, 237-251.

Guesdon JL, Ternynck T, Avrameas S. 1979. The use of avidin-biotin interaction in immunoenzymatic techniques. J Histochem Cylochem 27, 1131-1139.

Harlow E, Lane D. 1988. Antibodies, a laboratory manual. Cold spring harbor laboratory, USA.

Hsu SM, Raine L, Fanger $H$. 1981. Use of avidin-biotin-peroxidase complex (ABC) in immunoperoxidase techniques. J Histochem Cytochem 29, 577-580.

Hsu SM, Raine L, Fanger H. 1981. A comparative study of the peroxidase-antiperoxidase method and an avidin-biotin complex method for studying polypeptide hormones with radioimmunoassay antibodies. Am $\mathrm{J} C$ lin Pathol 75, 734-738.

Knowlton AA, Apstein CS, Sauoaf R, Brecher P. 1989. Leakage of heart fatty acid-binding protein with ischemia and reperfusion in the heart. J Mol Cell Cardiol 21, 577-583.

Koerker DJ, Sweet IR, Baskin DG. 1990. Insulin binding to individual rat skeletal muscles. Am J Physiol 259 E517-E523.

Lehninger AL. 1975. Biochemistry, 2nd edition, chapter 27. Worth publishers Inc., New York, USA.

LInssen MCJG, Vork MM, de Jong YF, Glatz JFC, Van der Vusse GJ. 1990. Fatty acid oxidation capacity and fatty acid-binding protein content of different cell types isolated from rat heart. Mol Cell Biochem 98, 19-25.

Matarese V, Stone RL, Waggoner DW, Bernlohr DA. 1990. Intracellular fatty acid tratficking and the role of cytosolic lipid binding proteins. Prog Lipid Res 28, 245-272.

Paulussen RJA, Geelen MJH, Beynen AC, Veerkamp JH. 1988. Immunochemical quantitation of fatty acidbinding proteins. I. Tissue and intracellular distribution, post-natal development and influence of physiological conditions on rat heart and liver fatty acid-binding protein. Biochim Biophys Acta 1001, 201-209.

Peeters RA, Veerkamp JH, Kanda T, Ono T, Geurts van Kessel A. 1991. Cloning of the cDNA encoding human skeletal muscle fatty acid-binding protein, its peptide sequence and chromosomal localization. Biochem J 276, 203-207.

Porstmann B, Porstmann T, Gaede D, Nugel E, Egger E. 1981. Temperature dependent rise in activity of horseradish peroxidase caused by non-ionic detergents and its use in enzyme-immunoassay. Clin Chim Acta $109,175 \cdot 181$. 
Snoeckx LHEH. 1987. Ischemia tolerance of the hypertrophied rat heart. PhD, thesis. University of Limburg, Maastricht, The Netherlands.

Van Nieuwenhoven FA, Vork MM, Surtel DAM, Kleine AH, Glatz JFC, Van der Vusse G.J. 1991. High-yield two-step chromatographic procedure for purification of fatty acid-binding protein from human heart. $J$ Chromatography 570, 173-179.

Veerkamp JH, Paulussen R.JA, Peeters RA, Maatman RGHJ, van Moerkerk HTB, Van Kuppevelt THMSM. 1990. Detection, tissue distribution and(sub)cellular localization of fatty acid-binding protein types. Mol Cell Biochem 98, 11-18.

Veerkamp JH, Peeters RA, Maatman RGHJ. 1991. Structural and functional features of different types of cytoplasmic fatty acid-binding proteins. Biochim Biophys Acta 1081, 1-24.

Wilchek M, Bayer EA. 1988. The avidin-biotin complex in bioanalytical applications. Anal Biochem 171, 1-32. Zivin JA, Waud DR. 1982. How to analyze binding, enzyme and uptake data: The simplest case, a single phase. Life Sciences 30,1407-1422. 


\section{CHAPTER 5}

\section{HETEROGENEOUS DISTRIBUTION OF FATTY ACID-BINDING PROTEIN IN HEARTS OF WISTAR KYOTO AND SPONTANEOUSLY HYPERTENSIVE RATS}

Michaël M. Vork, Nathalie Trigault, Luc H.E.H. Snoeckx, Jan F.C. Glatz and Ger J. Van der Vusse

J Mol Cell Cardiol 24, 317-321, 1992. (reprinted with permission) 


\section{SUMMARY}

In the present study we investigated the concentrations of cardiac cytoplasmic fatty acid-binding protein (FABP) in various regions of the left and right ventricles of both Wistar Kyoto rats (WKY) and spontaneously hypertensive rats (SHR). To this end, the ventricles of six WKY and six SHR hearts were cut in three slices, which were further dissected in one right ventricular piece and ten left ventricular pieces (five inner layer and five outer layer pieces). After homogenisation, FABP was assessed using an Enzyme Linked Immuno Sorbent Assay (ELISA) of the sandwich type. It was found that, when expressed per gram wet tissue, the overall concentration of FABP tended to be lower in SHR than in WKY hearts $(874 \pm 53 \mu \mathrm{g} / \mathrm{g}$ and $955 \pm 51 \mu \mathrm{g} / \mathrm{g}$, respectively; $0.1<p<0.2$, mean $\pm S E M$ for $n=6$ animals in each group). However, due to a $30-35 \%$ higher ventricular heart mass in SHR than in WKY, the total FABP content per heart turned out to be about $20 \%$ higher in SHR than in WKY rats. No concentration differences could be detected between right and left ventricles in WKY and SHR but a marked difference between the outer layer and the inner layer of the left ventricular wall was monitored in both groups. In general, the concentration in the outer layer was 5-15\% higher than in the corresponding inner layer. These differences reached the level of significance $(p<0.05)$ in regions close to the basis of the heart.

\section{INTRODUCTION}

Heart type cytoplasmic fatty acid-binding protein (FABP) is one of the most abundant proteins present in the cardiomyocyte as it constitutes $3-6 \%$ of the total cytosolic protein mass (Glatz et al, 1984). Although its exact physiological function is yet unknown FABP is believed to play a crucial role in fatty acid transport in the cardiac cell (Bass,1988; Glatz et al,1990; Matarese et al,1990; Veerkamp et al,1991). The heart can use a variety of substrates depending on the circumstances in which it must perform its function. Under resting and fasting conditions the heart predominantly uses fatty acids (60\%) as substrates to generate energy for its contractile activity (Opie,1986).

It could be assumed that differences in workload might result in concentration differences of factors involved in fatty acid oxidation, such as FABP. Therefore, intra-cardial (left ventricle versus right ventricle) differences in FABP concentration might exist. Secondly, differences can be hypothesized between hearts with permanently enhanced workload as in spontaneously hypertensive rat hearts and hearts with normal workload such as Wistar Kyoto rat hearts. It is known that the heart has an extraordinary capability to adapt to changes in the organism (Katz and Katz,1989).

The aim of the present study was to obtain insight into the intra-cardial and inter-cardial distribution of FABP. For this we compared the FABP concentration in different parts of hearts from male spontaneously hypertensive rats (SHR) and male Wistar Kyoto rats (WKY). Moreover, it was investigated whether transmural FABP concentration differences exist in the heart. This was done because it is still a point of debate whether the transmural workload of the heart is inhomogeneously distributed and, furthermore, whether the capacity to oxidize fatty acids is different between the inner and outer layers of the left ventricle (Van der Vusse et al,1990). 


\section{MATERIALS AND METHODS}

\section{Treatment of cardiac tissue}

All chemicals used were purchased from Sigma (St. Louis, MO, USA) unless indicated otherwise. Rats were mildly anaesthetized with diethylether after which the hearts were rapidly removed. In order to remove residual blood, the hearts were perfused retrogradely via the aorta with $40 \mathrm{ml}$ Tyrode buffer $\left(128 \mathrm{mM} \mathrm{NaCl}, 4.7 \mathrm{mM} \mathrm{KCl}, 0.4 \mathrm{mM} \mathrm{Na}_{2} \mathrm{HPO}_{4}, 1.3\right.$ $\mathrm{mM} \mathrm{CaCl}_{2}, 1.0 \mathrm{mM} \mathrm{MgCl}_{2}, 20.2 \mathrm{mM} \mathrm{NaHCO}_{3}$ and $11 \mathrm{mM}$ glucose equilibrated with $95 \% \mathrm{O}_{2}$ and $5 \% \mathrm{CO}_{2}, \mathrm{pH} 7.4$ ) at $37^{\circ} \mathrm{C}$. The ventricles of hearts of 6 male SHR (total body weight $316 \pm 7 \mathrm{~g}$, age 6 months), and 6 age-matched control male WKY rats (total body weight $326 \pm 13 \mathrm{~g}$ ) were divided in three slices parallel to the basis of the heart (Figure 5.1, left panel). Each tissue slice was further divided into eleven pieces as indicated in Figure 5.1, right panel. The atria and the apex part were discarded. Each tissue piece was weighed and homogenized in PBT medium, consisting of $10 \mathrm{mM}$ sodium phosphate, $154 \mathrm{mM}$ sodium chloride, $0.05 \%$ Tween 20 (Merck, Darmstadt, FRG) and $0.1 \%$ bovine serum albumin, $\mathrm{pH}$ 7.4, using an ultraturrax homogenizer (Janke und Kunkel, Staufen im Breisgau, FRG). Thereafter the homogenates were centrifuged for 15 minutes at $10,000 \times g$ and $4{ }^{\circ} \mathrm{C}$.
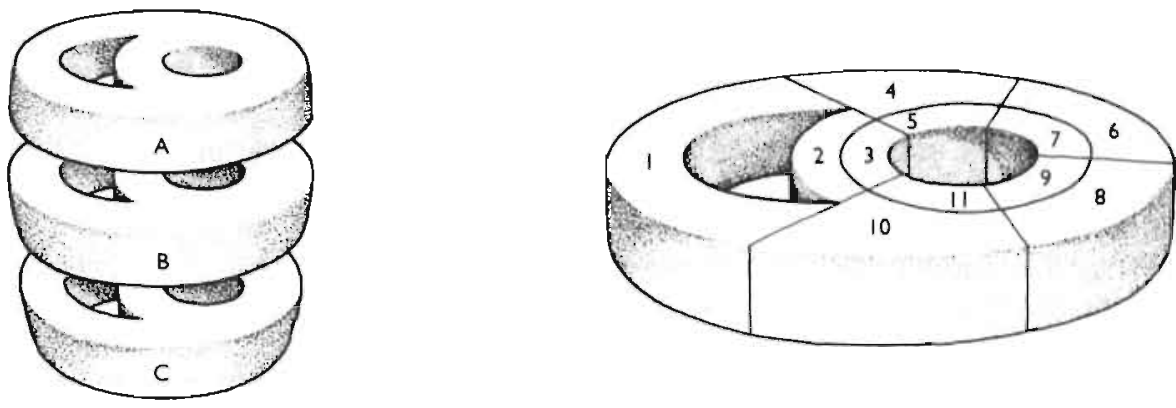

Fig. 5.1. Cutting procedure of ventricular tissue

\section{FABP assessment}

After the supernatants of the homogenates were diluted 10,000 to 30,000 times, FABP was assessed with a highly sensitive, disturbance insensitive Enzyme Linked Immuno Sorbent Assay of the sandwich type as described in chapter 4 (Vork et al, 1991) with a slight modification. In short, $50 \mu$ sample was pipetted into a PVC microtiterplate (Becton Dickinson, Oxnard, CA, USA), previously coated with $100 \mathrm{ng}$ affinity-purified anti rat FABP IgG for 90 minutes at $37^{\circ} \mathrm{C}$. After incubation overnight at $4^{\circ} \mathrm{C}$, the plates were incubated with $200 \mathrm{ng}$ of biotinylated anti H-FABP $\operatorname{lgG}(\mathrm{b}-\mathrm{lgG})$. Bound b-lgG was then detected with a preformed complex of streptavidin and biotinylated horse-radish peroxidase (b-HRP). Finally, bound b-HRP was visualized with a peroxidase substrate solution, containing $20 \mathrm{mM}$ o-phenylene diamine and $6 \mathrm{mM} \mathrm{H}_{2} \mathrm{O}_{2}$. The incubation time lasted for 10-20 minutes, after 
which the reaction was terminated with the addition of $50 \mu \mathrm{l} 4 \mathrm{~N} \mathrm{H}_{2} \mathrm{SO}_{4}$. Plates were read at $492 \mathrm{~nm}$ using a Titertek Multiskan II microtiterplate reader (Flow laboratories, Zwanenburg, The Netherlands). Subsequently, the concentration of FABP in all tissue pieces were calculated.

\section{Statistical treatment of data}

All data were expressed as mean \pm SEM. Student's $t$-test was used to detect statistical differences in the various measurements. For the detection of transmural differences in the hearts of both groups an analysis of variance was performed on data obtained from the inner tissue layer compared with data obtained from the outer layer, either in whole heart or in separate tissue slices. Differences were regarded statistically significant at $p<0.05$.

\section{RESULTS AND DISCUSSION}

The FABP concentration in SHR and WKY ventricles amounted to $874 \pm 53 \mu \mathrm{g} / \mathrm{g}$ wet weight and $955 \pm 51 \mu \mathrm{g} / \mathrm{g}$ wet weight, respectively (see Table 5.1. for detailed results). No differences in FABP concentration between the left and right ventricle could be observed in either SHR or WKY. It is worth to note that the FABP concentration in hearts from SHR tended to be lower than in WKY hearts although the difference was not statistically significant $(0.1<p<0.2)$. The present findings disagree with those of Fujii and colleagues (Fujii et al,1988) that chronically elevated blood pressure, as observed in SHR, results in enhanced cardiac FABP concentration. A possible explanation for this discrepancy is the fact that these investigators did not measure FABP in a direct manner. Instead, they measured the capacity of a cardiac cytosolic preparation to bind fatty acids. Since this technique is not completely specific and disturbance free (Vork et al,1990) it is uncertain whether the results of their study really indicates high blood pressure induced high FABP concentrations in the hearts of SHR.

When the content of FABP was calculated (expressed as $\mu \mathrm{g}$ per piece of tissue or total left ventricle), FABP tended to be higher in SHR than in WKY hearts. The difference reached the level of significance in some parts of the free wall and in the totaled outer layer of the left ventricular wall (Table 5.1., right hand panel). It should be stated that these differences were due only to a higher mass in SHR hearts and not to a higher FABP concentration in particular heart areas. Hence, the present findings permit the conclusion that chronically enhanced workload results in an increase in left ventricular weight rather than in an elevation of the FABP concentration in the left ventricle, as observed by Fujii and colleagues (1988).

In Table 5.2. the results of the analysis of variance are presented concerning FABP concentration differences between outer and inner tissue layers. Both in SHR and WKY hearts, FABP concentration differences between left ventricular outer and inner layers were found. In the outer part of hearts from both groups the FABP concentration is approximately $5-15 \%$ higher than that in the inner layer. When the separate slices were regarded, it was found that in all slices the mean value of the FABP concentration was higher in the outer layer than in the inner layer. However, these differences were only significant in slice $B$ of SHR and slice $A$ of $W K Y$, i.e. more to the basis of the heart.

In their review, Van der Vusse et al (1990) reported a small but significant difference (in the order of $10 \%$ ) between outer and inner layers in the fatty acid oxidation capacity, in favour of the former part, in dog heart. In the present study, a comparable transmural difference in the concentration of FABP from outer to inner layer was detected in rat heart 


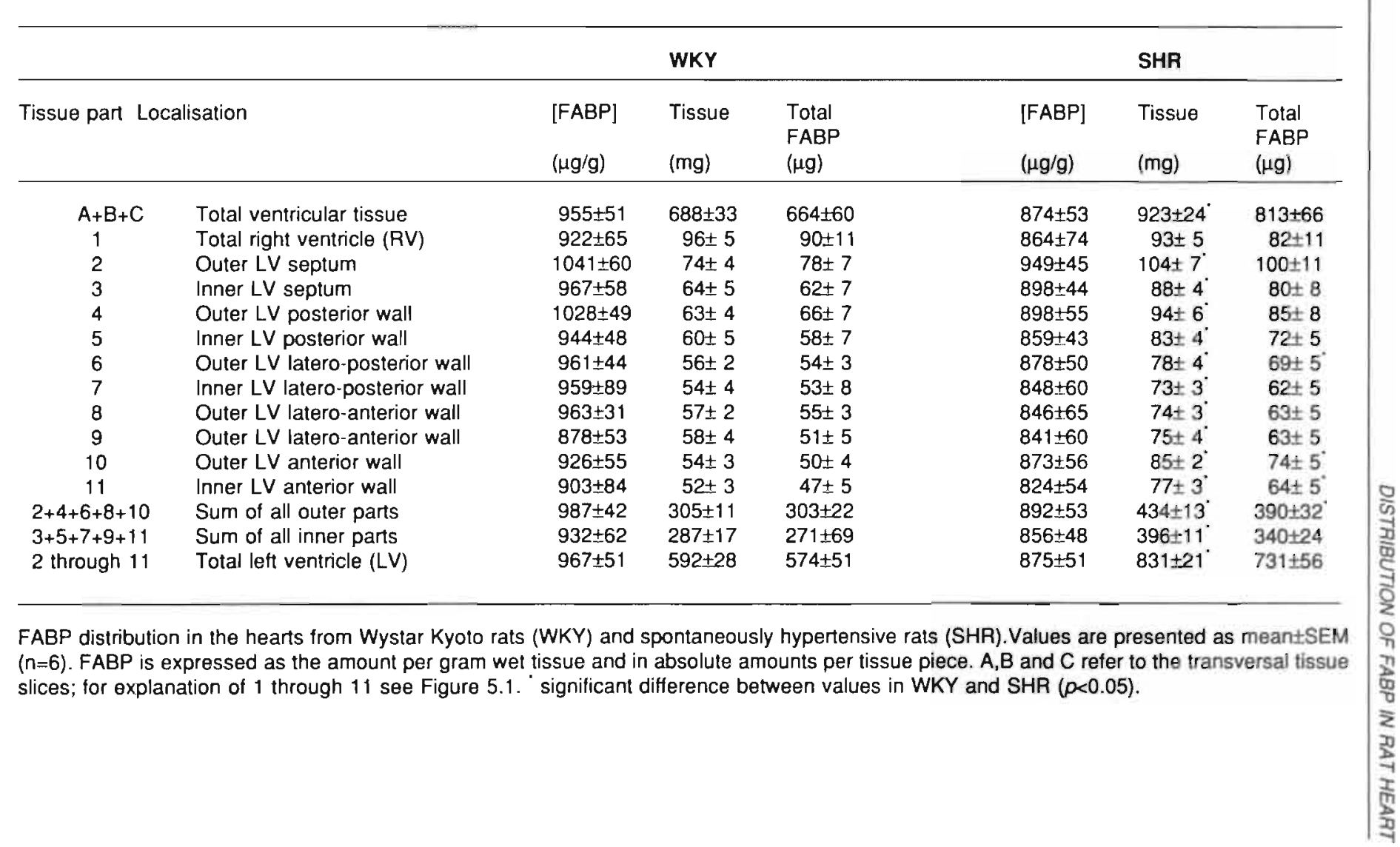


slices. These two findings indicate that the actual concentration of FABP in a particular region of the heart is related to the maximum rate of fatty acid oxidation, therein suggesting an important role of this protein in cardiac lipid metabolism.

\begin{tabular}{lccc}
\hline Tissue part & $\begin{array}{c}\text { Outer layer } \\
(\mu \mathrm{g} / \mathrm{g})\end{array}$ & $\begin{array}{c}\text { Inner layer } \\
(\mu \mathrm{g} / \mathrm{g})\end{array}$ & $p$-value \\
\hline WKY & & & \\
Whole heart & $975 \pm 23$ & $894 \pm 25$ & $<0.001$ \\
Slice A & $962 \pm 44$ & $818 \pm 39$ & $<0.001$ \\
Slide B & $957 \pm 48$ & $868 \pm 48$ & 0.07 \\
Slide C & $1007 \pm 27$ & $998 \pm 39$ & 0.7 \\
\hline & & & \\
SHR & & & $<0.001$ \\
Whole heart & $877 \pm 16$ & $844 \pm 17$ & 0.1 \\
Slice A & $853 \pm 22$ & $832 \pm 24$ & $<0.001$ \\
Slice B & $911 \pm 34$ & $845 \pm 34$ & 0.1 \\
Slice C & $897 \pm 28$ & $870 \pm 28$ & \\
\hline
\end{tabular}

Table 5.2. Transmural FABP concentration differences in the left ventricular wall of hearts from Wistar Kyoto rats (WKY) and spontaneously hypertensive rats (SHR).Values are expressed as mean \pm SEM ( $n=30$ for individual tissue slices, $n=90$ for total ventricular tissue). $p$-values are given to show significance of measured values. A,B and $\mathrm{C}$ refer to transversal tissue slices; see Figure 5.1.

\section{ACKNOWLEDGEMENT}

The authors wish to thank Mr. Otto Vork for the preparation of Figure 5.1. This study was supported by the Netherlands Heart Foundation, grant no. 88.073.

\section{REFERENCES}

Bass NM. 1988. The cellular fatty acid binding proteins: Aspects of structure, regulation and function. Int Rev Cytology 111,143-184.

Fujii S, Kawaguchi H, Okamota H, Saito H, Togashi H, Yasuda H. 1988. Fatty acid binding protein of cardiac muscle in spontaneously hypertensive rats: Effect of hypertrophy and its regression. $J$ Mol Cell Cardiol 20 , 779-787.

Glatz JFC, Baerwaldt CCF, Veerkamp JH, Kempen HJM. 1984. Diurnal variation of cytosolic fatty acid-binding protein content and of palmitate oxidation in rat liver and heart. J Biol Chem 259, 4295-4300.

Glatz JFC, Van der Vusse GJ. 1990. Cellular fatty acid-binding proteins: current concepts and future directions. Mol Cell Biochem 98, 237-251.

Katz AM, Katz PB. 1989. Homogeneity out of heterogeneity. Circulation 79, 712-717.

Matarese V, Stone RL, Waggoner DW, Bernlohr DA. 1990. Intracellular fatty acid trafficking and the role of cytosolic fatty acid binding proteins. Prog Lipid Res 28, 245-272.

Opie LH. 1986. The heart: Physiology, Metabolism, Pharmacology and Therapy, pp 111-117. Grune and Stratton Lid, London, UK.

Van der Vusse GJ, Arts T, Glatz JFC, Reneman RS. 1990. Transmural differences in energy metabolism of the left ventricular myocardium: Fact or fiction. J Mol Cell Cardiol 22, 23-37.

Veerkamp JH, Peeters RA, Maatman RGHJ. 1991. Structural and functional features of different types of cytoplasmic fatty acid-binding proteins. Biochim Biophys Acta 1081, 1-24.

Vork MM, Glatz JFC, Surtel DAM, Van der Vusse GJ. 1990. Assay of the binding of fatty acids by proteins: evaluation of the Lipidex 1000 procedure. Mol Cell Biochem 98, 113-117.

Vork MM, Glatz JFC, Surtel DAM, Knubben HJM, Van der Vusse GJ. 1991. A sandwich enzyme linked immuno-sorbent assay for the determination of rat heart fatty acid-binding protein using the strepavidin-biotin system. Biochim Biophys Acta 1075, 199-205. 
CHAPTER 6

\section{ON THE MECHANISM OF LONG CHAIN FATTY ACID TRANSPORT IN CARDIOMYOCYTES AS FACILITATED BY CYTOPLASMIC FATTY ACID-BINDING PROTEIN}

Michaël M. Vork, Jan F.C. Glatz and Ger J. Van der Vusse

· J Theor Biol 160, 207-222, 1993. (reprinted with permission) 


\section{SUMMARY}

Fatty acid-binding protein (FABP) is abundantly present in the cytoplasm of the cardiomyocyte, i.e. the cell which causes the contractile activity of the heart. Although FABP is thought to act as an intracellular long chain fatty acid (FA) carrier, definite experimental proof on this putative function has yet to be obtained. In the present study, experimental results from several authors were combined in an attempt to elucidate the precise physiological function of FABP in cardiac FA transport. It was calculated that, under normal conditions, the major part of FA in the cardiomyocyte is dissolved in lipid bilayers and that the presence of FABP in the heart enhances the aqueous solubility of FA more than 700 fold despite the fact that only a minor part $(<2 \%)$ of the total FABP content is then complexed with FA. Moreover, it is shown that, due to the enhanced cytoplasmic solubility, the FA flux from sarcolemma (the cellular membrane of the cardiomyocyte) to mitochondria is increased at least 17-fold in the presence of physiological amounts of FABP compared with the hypothetical situation in which FABP is absent. These calculations indicate the involvement of FABP in the transport of FA from the sarcolemma to those mitochondria lying in the innermost region of the cardiomyocyte. The extent to which FABP facilitates FA trafficking through the cytoplasm of the cardiomyocyte under physiological circumstances remains, however, to be established.

\section{INTRODUCTION}

Under normal conditions the heart predominantly uses long chain fatty acids (FA) for oxidative production of high energy phosphates in order to meet its energy requirements (For reviews see Camici et al, 1989; Van der Vusse et al, 1992). FA are supplied to the parenchymal cells of the heart (cardiomyocytes) via the blood, either complexed to albumin or as triacylglycerols in lipoprotein particles. On their route from the intravascular space to the interior of the cardiomyocyte various barriers have to be crossed, i.e. the endothelial cell lining of the capillary blood vessels, the interstitial space and the sarcolemmal membrane. Despite the high efficiency of uptake of FA by the heart (up to $70 \%$ of total FA during one single transit time), knowledge regarding the underlying mechanisms of FA transport across these barriers is limited (Bassingthwaighte et al, 1989). After entering the cardiomyocyte, intracellular transport has to ensure delivery of the FA molecules to the site of activation, i.e. the conversion of FA into acyl CoA by acyl CoA synthetase, an enzyme localized at the outer membrane of the mitochondria. The subsequent fate of the activated FA may be either incorporation of the acyl moieties into endogenous triacylglycerols or phospholipids, or oxidation inside the mitochondria and, to a lesser extent, in peroxisomes. In the normal functioning cardiomyocyte, the majority of FA will enter the mitochondrial oxidative pathway (Van der Vusse et al, 1992). In the resting rat heart the rate of FA oxidation is $50-100 \mathrm{nmol}$. min $^{-1}$ per gram wet weight tissue (Bielefeld et al, 1985; Forsey et al, 1987; Lopaschuk et al, 1990), while the maximal oxidation rate estimated from in vitro measurements on tissue homogenates is about $700 \mathrm{nmol} \cdot \mathrm{min}^{-1}$ per gram wet weight tissue (Glatz et al, 1984).

The transport of FA inside the cardiomyocyte is still incompletely understood. FA have an extremely low solubility in water. Brodersen et al (1989) reported an aqueous solubility of oleic acid as low as $2 \mathrm{nM}$. However, in the myocardium a small cytoplasmic fatty acidbinding protein (FABP, $15 \mathrm{kDa}$ ) is present in relatively high concentrations $\left(0.7-0.8 \mathrm{mg} \cdot \mathrm{g}^{-1}\right.$ tissue in the rat heart; Vork et al, 1991a). Although much information is presently available about structure and fatty acid-binding characteristics of several types of FABP (Bass, 1988; 
Glatz and Van der Vusse, 1990; Matarese et al, 1990; Veerkamp et a!, 1991) little direct evidence is available on the possible FA transport function of FABP (Ockner et al, 1972).

Recently, Waggoner and Bernlohr (1990) showed that in an adipocyle culture (3T3-L1 cells), adipocyte lipid binding protein, which is a member of the FABP family, actually was able to bind FA in vivo. This was the first direct proof that in vivo FABP is (partially) complexed with FA.

A decade ago, Tipping and Ketterer (1981) proposed a theoretical model for the facilitation of intracellular FA transport by FABP in the hepatocyte. They assumed that FABP would be able to increase greatly the aqueous solubility of FA in the hepatocyte cytoplasm, thus increasing its overall transport (diffusion) through the aqueous cytoplasm from the plasma membrane to the mitochondrial membrane. They concluded that FABP would be able to enhance the rate of intracellular FA transport by at least one order of magnitude. Since heart and liver differ substantially with respect to the metabolism of FA as well as the kinetic properties of their FABP types (Storch and Bass, 1990), extrapolation of hepatocyte data to other parenchymal cells should be performed with care. Although attempts made by Stewart and colleagues (1991) to determine the influence of heart-type FABP on FA transport in an aqueous environment showed an increase in FA translocation, it remains uncertain whether their conclusions indeed describe the mechanism of the enhancement of intracellular FA transport by FABP (Vork et al, 1991b).

The aim of the present study was to obtain insight into the significance of cytoplasmic FABP for the enhancement of unidirectional transport of FA by facilitated diffusion inside cardiac myocytes, using data on binding characteristics and myocardial content of FABP for rat heart as recently obtained in our laboratory as well as by others. Equations describing steady-state diffusion of FA are derived first after which these are applied to the intramyocytal diffusion of FA.

\section{METHODS AND RESULTS}

Diffusion is the most likely mechanism of FA transport inside the cardiomyocyte. In Figure 6.1. a simplified model of the cardiomyocyte and its extracellular environment is presented in which the problem dealt with in this chapter is schematically depicted. The basic question is by what means FA can be transported from the sarcolemma to the mitochondrial membrane in an effective fashion. FA shows a high affinity for a hydrophobic environment (i.e. lipid bilayers) and a low affinity for an aqueous environment (i.e. the cardiomyocytal aqueous cytoplasm). The main issue that was addressed in this study is whether the presence of FABP is necessary to explain the experimentally observed rates of FA utilization in the heart. The mechanism of aqueous diffusion will be discussed and then will be applied to the myocytal situation.

\section{Diffusion in liquid media}

Consider a fluid system in which a concentration difference of a certain solute exists. As a result of this concentration difference a net flux of the solute from the site of high concentration to the site of low concentration will be observed, despite the fact that the individual molecules will exhibit a random Brownian motion in any direction. Fick (1855) was the first to describe this phenomenon in mathematical terms. He found the following relation for the concentration gradient and solute transport in one direction: 


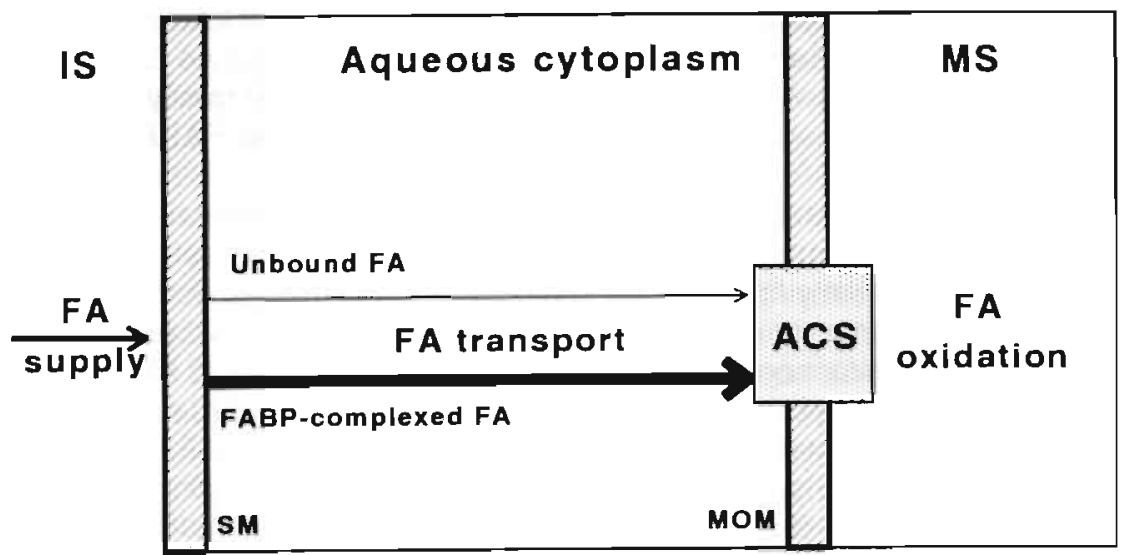

Fig. 6.1. Schematic representation of cardiac long chain fatty acid uptake, transport and utilization. $A C S=a c y \mid C O A$ synthetase, FA=fatty acid, IS=interstitial space, MS=mitochondrial space, $\mathrm{SM}=$ sarcolemmal membrane, $\mathrm{MOM}=$ mitochondrial outer membrane.

$d Q / d t=D \cdot A \cdot d C / d u$

[Eq. 6.1]

in which

Q = absolute amount of solute (mol)

$1=$ time (s)

$\mathrm{dQ} / \mathrm{dt} \quad$ solute migration per unit of time, or diffusional flux $\left(\mathrm{mol} \cdot \mathrm{s}^{-1}\right)$

$\mathrm{D}=$ diffusion coefficient $\left(\mathrm{cm}^{2} \cdot \mathrm{s}^{-1}\right)$

A $\quad=$ surface through which diffusion occurs $\left(\mathrm{cm}^{2}\right)$

C = solute concentration $\left(\mathrm{mol} \cdot \mathrm{cm}^{-3}\right)$

$\mathrm{u} \quad=$ distance between two points under observation $(\mathrm{cm})$

$\mathrm{dC} / \mathrm{du}=$ concentration gradient of the solute $\left(\mathrm{mol} \cdot \mathrm{cm}^{-4}\right)$

The simplest solution of this differential equation is:

$$
Q / t=D \cdot A \cdot \Delta C / U
$$

In order to apply this simple relation to the physiological system, the cardiomyocyte in which FABP and FA diffusion occurs (Fig 6.1), the relation has to be subjected to several modifications. For the sake of clarity each parameter involved in the system will be discussed separately below.

\section{Diffusional surface (A)}

In equation 6.2 the diffusion in one direction is described. To calculate the diffusional flux of FA from the sarcolemma to the mitochondrial membrane it is necessary to have values for the number of cardiomyocytes per gram of heart tissue and for the areas of the two membranes involved. Page and McCallister (1973) measured the relative space 
distribution in the heart and found that approximately $60 \%$ of the total volume is occupied by cells whereas the rest is reserved for the intravascular space and the interstitial space. In addition, more than $90 \%$ of the cellular volume in the tissue was found to be occupied by cardiomyocytes. Anversa et al (1980) studied the morphometry of the papillary muscle in detail. This cardiac muscle is frequently used as a model for cardiomyocytes in the ventricular wall. Surface measurements in papillary muscle revealed that the total cell membrane surface per myocyte amounts to $4000 \mu \mathrm{m}^{2}$, including intercalated disks and $\mathrm{T}$. tubule system, whereas the total outer mitochondrial surface was found to amount to 16000 $\mu \mathrm{m}^{2}$ per cell. Moreover, the mean cardiomyocyte volume was found to be approximately $8000 \mu \mathrm{m}^{3}$. Assuming that $1 \mathrm{~g}$ tissue equals $1 \mathrm{ml}$ tissue, it can be calculated that one gram heart tissue contains approximately $75 \cdot 10^{6}$ myocytes and that the average sarcolemmal surface amounts to $0.3 \mathrm{~m}^{2}$ per gram tissue, whereas the average myocytal mitochondrial surface amounts to $1.2 \mathrm{~m}^{2}$ per gram tissue. Making use of the average dimension of cardiomyocytes (diameter 10-25 $\mu \mathrm{m}$, length 50-100 $\mu \mathrm{m}$ ) (Dow et al, 1981) a similar average value $\left(0.3 \mathrm{~m}^{2}\right)$ for the sarcolemmal surface can be calculated, which validates the results obtained by Anversa et al (1980).

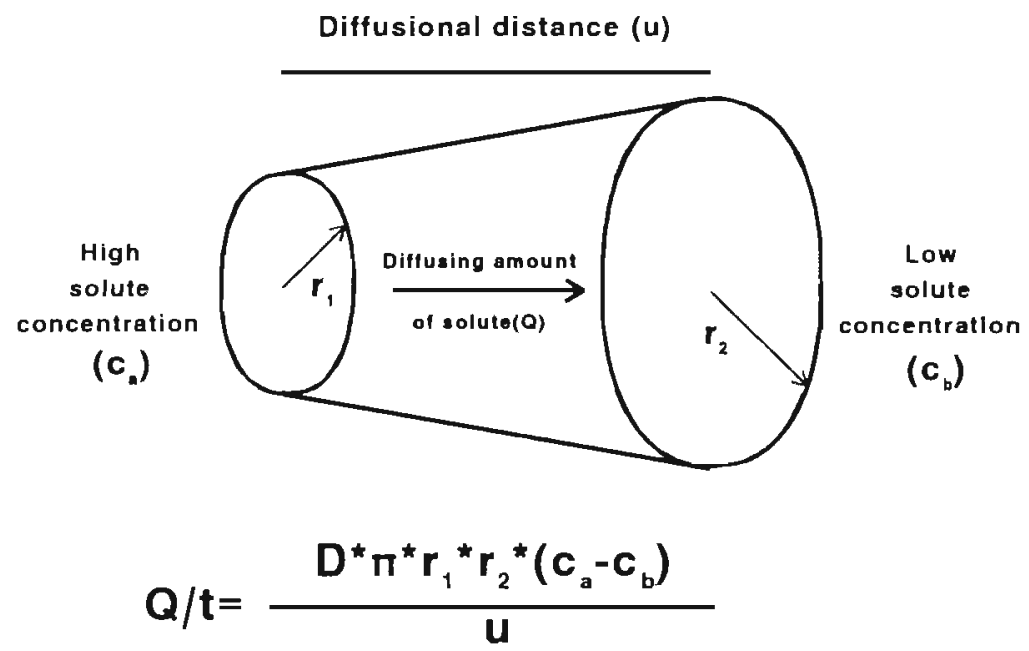

Fig. 6.2. Schematic representation of uni-directional diffusion between sarcolemtivil and outer mitochondrial membrane.

In the model for uni-directional diffusion formulated in equation 6.2 it is assumed that the surface area through which diffusion takes place remains unchanged during the prolongation of diffusion. However, in the cardiomyocyte this is not true because of differences in the surface areas between the sarcolemma and the mitochondria. The area which is crossed by the diffusional substance increases during extension of the unidirectional movement (Figure 6.2.). A similar system has been treated mathematically by Jacobs (1967) who found that such system can be described mathematically when the surfaces under investigation are regarded to be circular. The radii of both surfaces, $r_{s}$ (sarcolemmal surface) and $r_{m}$ (surface of the outer mitochondrial membrane) respectively, can then be incorporated in a slight modified version of Fick's law: 


$$
Q^{\prime} t=r_{s} \cdot r_{m} \cdot \pi \cdot D \cdot \Delta C / u
$$

[Eq. 6.3]

in which the product of $r_{s}, r_{m}$ and $\pi$ yields an average surface area. From the surfaces of the sarcolemmal $\left(0.3 \mathrm{~m}^{2}\right)$ and mitochondrial membrane $\left(1.2 \mathrm{~m}^{2}\right)$ the radii $r_{\mathrm{s}}$ and $r_{\mathrm{m}}$ correspond to $31 \mathrm{~cm}$ and $62 \mathrm{~cm}$, respectively. Substituting $r_{s}$ and $r_{m}$ in equation 6.3 results in an effective diffusional surface $\left(A^{\prime}=\pi \cdot r_{\mathrm{s}} \cdot r_{\mathrm{m}}\right)$ of approximately $0.6 \mathrm{~m}^{2}$ per gram heart tissue. In this situation it is assumed that the total outer mitochondrial surface is available for the uptake of FA. Equation 6.2 can now be modified to:

$$
\mathrm{Q} / \mathrm{t}=\mathrm{D} \cdot \mathrm{A}^{\prime} \cdot \Delta \mathrm{C} / \mathrm{u}
$$

[Eq. 6.4]

\section{Diffusional distance (u)}

Due to the T-tubule system of the cardiomyocyte the distance between any point in the cell and the sarcolemmal membrane is not more than $3 \mu \mathrm{m}$ (Bloom and Fawcett, 1975). Mitochondria are located between contractile elements but also close to the sarcolemmal membrane (Bloom and Fawcett, 1975). Thus the distance from the sarcolemma to the mitochondrial outer membrane may vary considerably, i.e. from $0-3 \mu \mathrm{m}$. For the present calculations an average diffusional distance of $1.5 \mu \mathrm{m}$ is assumed.

\section{Concentration gradient $(\Delta \mathrm{C})$}

To calculate the concentration gradient of FA in the cardiomyocyte, the total FA and FABP contents of rat heart under normal conditions, and the concentrations of unbound and FABP-bound FA should be known. De Groot et al (1989) found for rat heart perfused during 10 minutes with a glucose containing medium under normoxic conditions a total FA concentration of $72.4 \mathrm{nmol} \cdot \mathrm{g}^{-1}$ dry weight tissue. Since the dry weight amounts to approximately $16 \%$ of the total tissue mass (De Groot et al, 1989), the overall FA concentration is $12 \mu \mathrm{mol} \cdot \cdot^{-1}$ tissue volume. In dog heart, a comparable concentration of FA (23 $\mu \mathrm{mol} \cdot \mathrm{l}^{-1}$ tissue volume) was measured by Van der Vusse et al (1982), indicating that the amount of FA in the hearts of several species is very low under normoxic conditions.

It is highly unlikely that FA and FABP are equally distributed among cardiac tissue. Tipping and Ketterer (1981) indicated that FA might be present (1) complexed to FABP, (2) "free" in the aqueous cytoplasm or (3) solubilized in membrane structures (in the present case the sarcolemmal membrane). Hence it is necessary to gain insight into the distribution of FA between the three phases indicated. The distribution of FA between lipid membrane structures and FABP was studied recently by Storch and Bass (1990). They used several fluorescently labeled long chain fatty acids (anthroyloxy FA) to determine the distribution of these FA between FABP and artificial phospholipid (PL) bilayers. They defined a partition coefficient:

$$
K_{p}=\frac{(\% F A B P \text { bound } F A) /[F A B P]}{(100-\% F A B P \text { bound } F A) /[P L]} \quad \text { [Eq. 6.5] }
$$


in which

$K_{p}$

$\%$ FABP bound FA 100-\%FABP bound FA [FABP]

$[\mathrm{PL}]$
$=$ partition coefficient

=proportion of FA bound to FABP

=proportion of FA in phospholipid membranes

=concentration of FABP

=concentration of phospholipid (PL)

This partition coefficient had been defined earlier in a slightly different way by Noy and colleagues (1986) and resulted directly from the equilibrium equations of FA binding to FABP and to $\mathrm{PL}$ membranes. The measured value of the $\mathrm{K}_{\mathrm{p}}$ varied from 0.3 to 5 , depending on the anthroyloxy FA used, but on the average amounted to 2 (Storch and Bass, 1990). With this value it is possible to calculate the amount of FA present in the lipid membrane and the amount complexed to FABP, provided that the PL content is known.

The FABP content of rat heart was recently reported to amount to $0.74 \mathrm{mg} \cdot \mathrm{g}^{-1}$ wet weight tissue or $\left.50 \mu \mathrm{mol}^{-1}\right|^{-1}$ tissue volume (Vork et al, 1991a). The total PL content of rat heart was found to be $178 \mu \mathrm{mol} \cdot \mathrm{g}^{-1}$ dry weight, or $28 \mathrm{mmol} \cdot{ }^{-1}$ tissue volume (Van Bilsen et al, 1989). From data published by Anversa et al (1980), it can be calculated that the entire membrane surface area per gram heart tissue amounts to $9.2 \mathrm{~m}^{2}$, including all membranes present in endothelial cells, fibroblasts and cardiomyocytes. Since the sarcolemmal surface was found to be $0.3 \mathrm{~m}^{2}$ per gram tissue it can be inferred that the sarcolemmmal membrane surface amounts to only $3 \%$ of the total surface. Taken into account that the sarcolemmal membrane probably contains less protein than the bulk mitochondrial surface it is now assumed that $5 \%$ of the total myocardial amount of $\mathrm{PL}$ is present in the sarcolemmal membrane, i.e. $\left.1.4 \mathrm{mmol} \cdot\right|^{-1}$ tissue volume.

On the basis of the above calculated values the partition of FA between FABP and PL may now be obtained. However, it would then be assumed that FABP, PL and FA are distributed homogeneously among the myocardium, which is not the case. As already mentioned, in the heart the volume occupied by myocytes, in which FA, PL and FABP are considered to be present, amounts to $60 \%$. Earlier we showed that FABP is almost entirely located in cardiomyocytes and is absent in other cardiac cell types (Linssen et al, 1990). Moreover, in the present study it is assumed that the bulk of FA is also confined to the cardiomyocyte. Hence the corrected concentrations of FA, PL and FABP are $20 \mu \mathrm{mol} \cdot l^{-1}, 2.3$ mmol. $\left.\right|^{-1}$ and $85 \mu \mathrm{mol} \cdot l^{-1}$ cardiomyocytal volume, respectively. For FABP a further correction has to be made since the intracellular space which is accessible for FABP is less than the total cellular volume. Mitochondria contain negligible amounts of FABP (Underberg et al, 1989) but occupy at least $30 \%$ of the intracellular space (Page et al, 1973). Other intracellular structures, e.g. the nucleus and sarcoplasmic reticulum, occupy up to $10 \%$ of the total intracellular space. Myofibrils, located in the cytoplasmic space, represents the bulk of myocytal protein which constitutes a large part of the tissue dry weight. Hence, part of the cytoplasmic volume will not be accessible for solubilized substances (i.e. FABP) because it will be occupied by non solubilized protein (i.e. myofibrils). Therefore, the space accessible for $\mathrm{FABP}$ is estimated to be $50 \%$ of the total myocytal volume, which results in an effective FABP concentration of $170 \mu \mathrm{mol} \cdot l^{-1}$ cytoplasmic space.

Equation 6.5 does not allow the calculation of the cytoplasmic concentration of FA directly. First the distribution of FA between PL and FABP has to be calculated. Thereafter, the actual amount of FA present in the aqueous cytoplasm (bound to FABP) can be estimated using the value for the total myocytal FA content. Substituting the values for $\mathrm{PL}$ $\left(2.3 \mathrm{mmol} \cdot \mathrm{l}^{-1}\right)$ and $\operatorname{FABP}\left(170 \mu \mathrm{mol} \cdot \mathrm{I}^{-1}\right)$ in equation 5 reveals that under the conditions 
described FABP contains only $13 \%$ of the total FA whereas $87 \%$ of FA is associated with the sarcolemmal membrane. Since the total FA concentration was calculated to be 20 $\mu \mathrm{mol} \cdot{ }^{-1}$ cardiomyocytal volume, the concentration of FABP-FA complex will amount to $0.13 .20=2.6 \mu \mathrm{mol} \cdot \cdot^{-1}$ cytoplasm. Hence, the FA-free FABP concentration is $\left.167.4 \mu \mathrm{mol} \cdot\right|^{-1}$ cytoplasm (total FABP minus complexed FABP). Thus, in the present situation only $1.5 \%$ of the total FABP is complexed with FA. Interestingly, a similar low percentage of complexed FABP was predicted by Tipping and Ketterer (1981) in their model for the hepatocyte.

The stoichiometry of oleic acid binding by heart-type FABP previously has been reported to be 1:1. (Vork et al, 1990). Hence, the unbound FA concentration in the aqueous cytoplasm can be calculated with the equilibrium equation for FA and FABP:

$$
K_{d}=[F A B P] \cdot[F A] /[F A B P-F A]
$$

[Eq. 6.6]

in which

$\begin{array}{ll}\mathrm{K}_{\mathrm{d}} & =\text { dissociation constant }\left(\left.\mu \mathrm{mol} \cdot\right|^{-1}\right) \\ {[\mathrm{FABP}]} & =\text { concentration of FA-free FABP }\left(\left.\mu \mathrm{mol} \cdot\right|^{-1} \text { cytoplasm }\right) \\ {[\mathrm{FA}]} & =\text { concentration of unbound FA }\left(\left.\mu \mathrm{mol} \cdot\right|^{-1} \text { cytoplasm) }\right. \\ {[\mathrm{FA}-\mathrm{FABP}]} & =\text { concentration of the FABP-FA complex }\left(\left.\mu \mathrm{mol} \cdot\right|^{-1} \text { cytoplasm) }\right.\end{array}$

For oleic acid, the $\mathrm{K}_{d}$ amounts to $0.2 \mu \mathrm{M}$ (Vork et al, 1990). This $\mathrm{K}_{d}$ value for oleic acid will be used in all calculations. Using equation 6.5. an average cellular unbound FA concentration of $3.1 \mathrm{nM}$ can be calculated. This calculated concentration is in close agreement with the earlier reported value of $2 \mathrm{nM}$ for the aqueous solubility of oleic acid (Brodersen et al, 1989).

From equation 6.6 it follows that in the presence of FABP, the concentration of unbound FA depends on the concentration of FABP. In Figure 6.3. the concentration of unbound $F A$ is calculated at varying FABP concentrations using equations 6.5 and 6.6. From this graph it can be inferred that the concentration of unbound FA slightly increases at lower FABP concentration values, with a maximum concentration of $3.5 \mathrm{nM}$ in the hypothetical absence of FABP and the presence of $2.3 \mathrm{mmol} \mathrm{PL} \cdot \mathrm{l}^{-1}$ cytoplasm.

Although the amount of complexed FABP is relatively low compared with the total amount of FABP it can be observed that FABP increases the total amount of solubilized FA more than 700 fold $\left(2.6 \mu \mathrm{mol}^{-1}\right.$ cytoplasm versus $3.5 \mathrm{nmol} \cdot \mathrm{l}^{-1}$ cytoplasm). The concentrations of FA and FA-FABP as calculated with equation 6.6 represent average concentrations. In the calculation of the diffusional FA flux it is assumed that the concentrations of unbound and complexed FA are highest in close vicinity of the sarcolemmal membrane and close to zero at the mitochondrial membrane. These assumptions are justified since the activity of acyl-CoA synthetase, located at the outer mitochondrial membrane, most likely creates a sink for FA (Van der Vusse, 1992). However, it has to be kept in mind that the cellular distribution of total FABP (complexed and uncomplexed) remains completely homogeneous, despite the fact that a gradient of complexed FABP exists. A backflux of FABP will be constantly present as a result of random Brownian movement. 


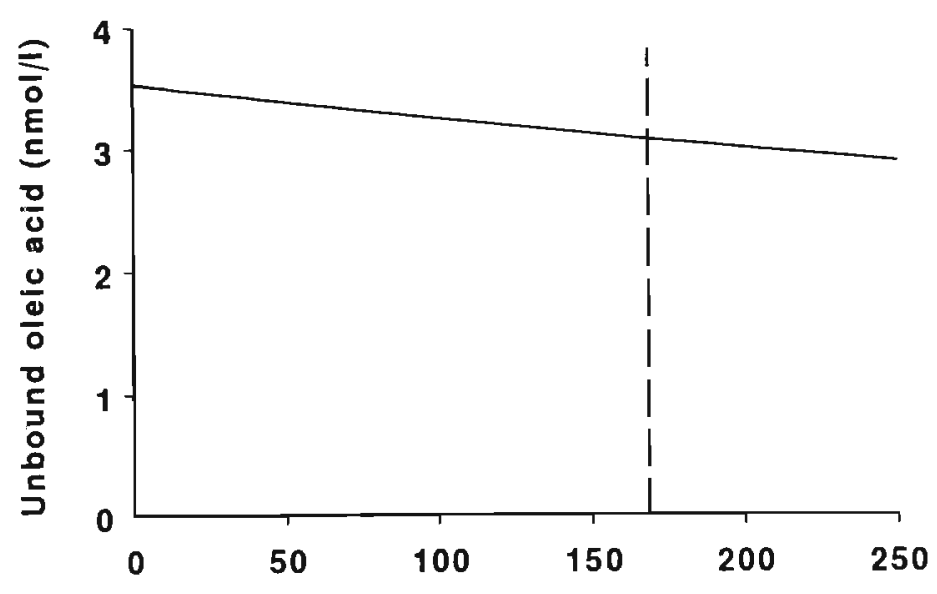

FABP $(\mu \mathrm{mol} / \mathrm{l})$

Fig. 6.3. Unbound oleic acid (OA) concentration as a function of the concentration of fatty acid-binding protein (FABP). OA concentrations were calculated using equations 6.5-6.6. The dotted line indicates the physiological FABP concentration

\section{Diffusion coefficient (D)}

The diffusion coefficient can be defined as the molar amount of the solute under investigation which crosses a surface area of $1 \mathrm{~cm}^{2}$ in one second between two points between which a concentration gradient of $1 \mathrm{~mol} \cdot \mathrm{cm}^{-3}$ exists. Historically, the diffusion coefficient is expressed as $\mathrm{cm}^{2} \cdot \mathrm{s}^{\cdot}$. Hence, the diffusional distance has to be expressed in $\mathrm{cm}$ and the solute concentrations in $\mathrm{mol} \cdot \mathrm{cm}^{-3}$. The diffusion coefficient mainly depends on the molecular radius of the solute, the viscosity of the solvent and the temperature (Jacobs, 1967). Since the molecular masses of FA and FABP, which are assumed to be linearly related to the molecular radius, differ considerably the diffusion coefticient of both solutes can be expected to differ as well.

The value of the diffusion coefficient of FA in water at infinitesimal small concentration is assumed to be similar to that of a water soluble substance with comparable molecular weight, e.g. sucrose $D=4.6 \cdot 10^{-6} \mathrm{~cm}^{2} \cdot \mathrm{s}^{-1}$ at $20^{\circ} \mathrm{C}$ (Van Holde, 1971). For FABP, the diffusion coefficient will be similar to that of myoglobin, a protein with a molecular mass (17.8 kDa) comparable with that of FABP. The diffusion of myoglobin in buffer at $20^{\circ} \mathrm{C}$ was reported to be $10.6 \cdot 10^{-7} \mathrm{~cm}^{2} \cdot \mathrm{s}^{-1}$ (Riveros-Moreno and Wittenberg, 1972). However, studies in rat heart muscle homogenates (Moll, 1968) or in the intact rat diaphragm muscle (Jürgens et al, 1990) revealed cellular diffusion coefficient values of $1.5 \cdot 10^{-7} \mathrm{~cm}^{2} \cdot \mathrm{s}^{-1}$ at $20^{\circ} \mathrm{C}$ (Moll, 1968) and $4.9 \cdot 10^{-7} \mathrm{~cm}^{2} \cdot \mathrm{s}^{-1}$ at $25^{\circ} \mathrm{C}$ (Jürgens et al, 1990), respectively. When Riveros-Moreno and Wittenberg (1972) assessed the diffusion coefficient of myoglobin in solutions containing high protein concentrations $\left.\left(250-300 \mathrm{~g}^{-1}\right)^{-1}\right)$ they measured a value of $4 \cdot 10^{-7} \mathrm{~cm}^{2} \cdot \mathrm{s}^{-1}$ at $20^{\circ} \mathrm{C}$, which is comparable with the findings of Jürgens et al (1990), i.e. a decrease in apparent diffusion coefficient of a factor 2 to 3 . However, Wojcieszyn et al (1981) observed a 70 fold decrease in apparent diffusion coefficient of fluorescently labeled albumin (68 kDa), once 
injected into the cytoplasm of human fibroblasts, compared with the diffusion in buffer, whereas the diffusion of the unbound fluorescent label (374 Da) was not influenced by the cytoplasm. The observed decrease in diffusion characteristics of albumin in the cytoplasm of the fibroblast may partially be caused by the fact that albumin is negatively charged at physiological $\mathrm{pH}$, due to its low iso-electric point ( $\mathrm{pl=4.8-5.3)}$ (Rothschild et al, 1988), thus possibly causing the protein to interact with intracellular structures which can result in a decrease in apparent diffusion coefficient. Since heart FABP is known to have a relatively low $p l$ value $(p l=5$ ) as well (Fournier et al, 1978), its diffusional properties may be influenced similarly. Taking into account the measured values of the diffusion coefficient of myoglobin, which has a neutral pl value, and the possible retardation of FABP due to its negative charge, the diffusion coefficient of FABP $\left(D_{F A B P}\right)$ in the cardiomyocyte is assumed to be approximately $1 \cdot 10^{-7} \mathrm{~cm}^{2} \cdot \mathrm{s}^{-1}$, whereas the diffusion coefficient for $F A\left(D_{F A}\right)$ is assumed to be $4.6 \cdot 10^{-6} \mathrm{~cm}^{2} \cdot \mathrm{s}^{-1}$.

\section{Diffusional flux of $F A(Q / t)$}

Since all variables in the equation for the diffusional flux (equation 6.4) are now inferred or estimated, the diffusional flux can be calculated for all situations described above. The diffusional flux can be regarded as two separate fluxes, viz. the unbound FA flux and the FA-FABP flux. The total flux can then be described as:

$$
Q / t=D_{F A} \cdot A^{\prime} \cdot[F A] / U+D_{F A B P} \cdot A^{\prime} \cdot[F A-F A B P] / u \quad[\text { Eq. 6.7] }
$$

Since FA oxidation values are expressed mostly as the amount of FA oxidized per minute, the flux will be calculated also in nmol per minute in order to compare these values with experimentally obtained data.

\section{FA diffusion in the absence of FABP}

In the absence of $F A B P$, equation 6.7 can be reduced to: $Q / t=D_{F A} \cdot A^{\prime} \cdot[F A] / u$, where $A^{\prime}=6000 \mathrm{~cm}^{2},[F A]=3.5 \mathrm{pmol} \cdot \mathrm{cm}^{-3}\left(3.5 \mathrm{nmol} \cdot I^{-1}\right), u=1.5 \cdot 10^{-4} \mathrm{~cm}$ and $D_{F A}=4.6 \cdot 10^{-6} \mathrm{~cm}^{2} \cdot \mathrm{s}^{-1}$. Substitution of all values results in a diffusional flux from the sarcolemmal to the mitochondrial membrane of approximately $0.65 \mathrm{nmol} \cdot \mathrm{g}^{-1}$ tissue per second, or $39 \mathrm{nmol} \cdot \mathrm{g}^{-1}$ tissue per minute.

\section{FA diffusion in the presence of FABP}

For the total FA flux in the presence of FABP the entire equation 6.7 is used where $A^{\prime}=6000 \mathrm{~cm}^{2},[F A]=3.1 \mathrm{pmol} \cdot \mathrm{cm}^{-3}\left(3.1 \mathrm{nmol} \cdot \mathrm{I}^{-1}\right), \mathrm{u}=1.5 \cdot 10^{-4} \mathrm{~cm}, \mathrm{D}_{\mathrm{FA}}=4.6 \cdot 10^{-6} \mathrm{~cm}^{2} \cdot \mathrm{s}^{-1}$, [FA-FABP] $=2.6 \mathrm{nmol} \cdot \mathrm{cm}^{-3}\left(2.6 \mu \mathrm{mol} \cdot \cdot^{-1}\right)$ and $D_{F A B P}=1 \cdot 10^{-7} \mathrm{~cm}^{2} \cdot \mathrm{s}^{-1}$. This results in a diffusional flux of $659 \mathrm{nmol} \cdot \mathrm{g}^{-1}$ tissue per minute in which unbound $\mathrm{FA}$ accounts for $35 \mathrm{nmol} \cdot \mathrm{g}^{-1}$ tissue per minute whereas FABP bound FA accounts for $624 \mathrm{nmol} \cdot \mathrm{g}^{-1}$ tissue per minute. From these results it appears that FABP induces a 17 fold increase in FA translocation from sarcolemma to mitochondria. The contribution of the FABP-facilitated FA diffusional flux can be calculated at various FABP concentrations making use of the equations 6.5-6.7. This resulted in the data visualized in Figure 6.4. in which the separate diffusional fluxes of uncomplexed FA and FABP bound FA are depicted as a function of the (theoretical) FABP concentrations. 


\section{DISCUSSION}

Experimental data on the role of FABP in intracellular FA transport are scarce. Recently, Stewart et al (1991) measured the diffusion of FA in the absence and presence of FABP and concluded that FABP caused an increase in FA diffusion. Although it is shown in the present study that heart-type FABP indeed causes an increase in the diffusional flux of FA, the conclusion of Stewart et al (1991) was not justified, since for technical reasons the findings obtained by these investigators can be criticized. It was concluded by these researchers that FABP was able to increase the diffusion coefficient of FA, which would imply that FABP is able to catapult FA through an aqueous solution. This mechanism obviously seems highly unlikely to occur (Vork et al, 1991b).

\section{FA distribution between FABP and lipid membranes}

Several research groups have studied the behaviour of $F A$ in the presence of FABP and lipid bilayers. McCormack and Brecher (1987) found that liver FABP was able to increase the FA flux between multilamellar liposomes and microsomes. Peeters and associates (1989) showed that FABP was able to "extract" oleic acid from a lipid monolayer. Moreover, they showed that FABP could increase the FA transport from liposomes to mitochondria, separated by a dialysis membrane, or between two lipid monolayers. The phenomenon of FA distribution between lipid bilayers and FABP has been frequently used to determine the dissociation constant of a FA-FABP complex as well as the maximal binding (Paulussen et al, 1988; Offner et al, 1986) as an alternative for the Lipidex 1000 assay (Glatz et al, 1983; Vork et al, 1990).

An elegant method of studying the kinetics of FA distribution between lipid bilayers and FABP was presented by Storch and Bass (1990). Some results of their work were used in the present study to calculate the FA distribution in the heart. However, one should bear in mind that these particular studies were performed with artificial phospholipid membranes in combination with anthroyloxy FA. Although it appears to be an acceptable model for the physiological situation, appreciable differences between the in vitro and the in vivo situation cannot be ruled out. Furthermore, since the reported values of the partition coefficient for several antroyloxy FA vary between 0.3 and 5 it is difficult to indicate which value approaches the partition of oleic acid between FABP and the cellular membrane of the cardiomyocyte in vivo.

\section{FA transport by FABP}

Although it is shown in the present study that FABP enhances the cardiac FA translocation considerably, the FABP-FA complex must dissociate fast in order to allow FA uptake by mitochondria. Storch and Kleinfeld (1986) studied the FA transfer between lipid bilayers and concluded that FA translocation occurs via the aqueous phase rather than by collision between bilayer fractions. Like Peeters et al (1989) they found that this process was hardly monitorable because of the high exchange velocity. Interestingly, Storch and Bass (1990) found that the dissociation rate constant of a heart FABP-FA complex was approximately 10 fold higher than that of a liver FABP-FA complex. Moreover, they found that the distribution of FA between FABP and lipid bilayers showed large differences between liver FABP and heart FABP, pointing out that heart FABP and liver FABP might have distinct physiological functions. This may relate to the relatively large difference in primary structure between these FABP types (Bass, 1988; Veerkamp, 1991). Taking the 
above mentioned considerations into account it must be concluded that the results obtained in the present study are applicable only to heart-type FABP and may not describe a general FA transport mechanism for all FABP types.

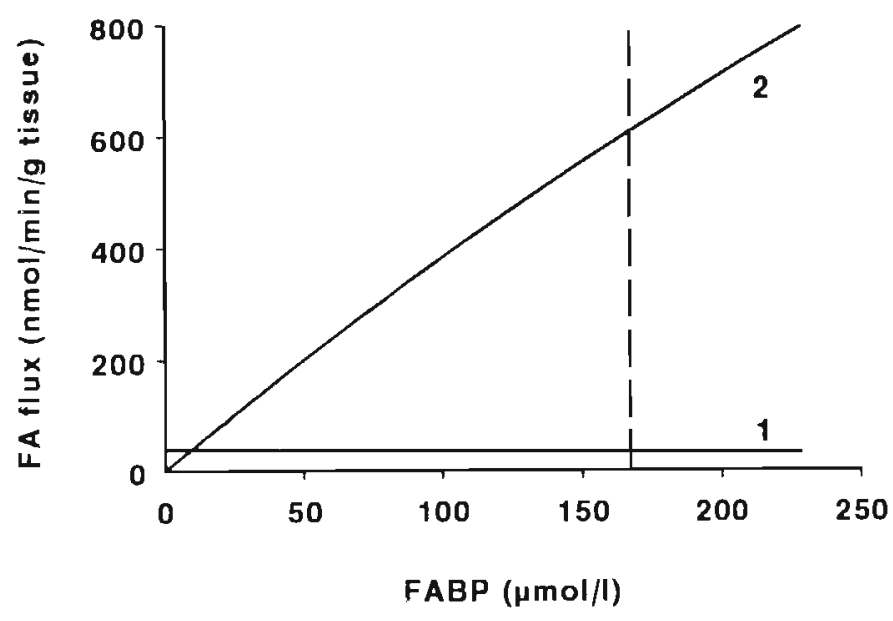

Fig. 6.4. Diffusional long chain fatty acid (FA) flux as a function of the concentration of fatty acid-binding protein (FABP). Results were calculated using equations 6.5-6.7. The dotted line indicates the physiological FABP concentration. 1. Unbound FA diffusional flux. 2. FABP-complexed FA diffusional flux.

Storch and Bass (1990) reported fast dissociation rate constants of the cardiac FABP. FA complex for different fluorescent fatty acids with a value between 0.5 and $1 \mathrm{~s}^{-1}$ at $24^{\circ} \mathrm{C}$. The rate of dissociation can be calculated with the ordinary equation for first order kinetics:

$$
C_{1}=C_{0} \cdot e^{(-k \cdot 1)}
$$

in which

$$
\begin{array}{ll}
C_{t} & =\text { concentration at time }=t \\
C_{0} & =\text { concentration at time }=0 \\
t & =\text { time } \\
k & =\text { dissociation rate constant }
\end{array}
$$

Since the present study deals with the situation in vivo, the dissociation constant at $37^{\circ} \mathrm{C}$ should be known. Assuming a two-fold increase in reaction velocity with every $10^{\circ}$ increase in temperature, the mean dissociation constant is estimated to be $2 \mathrm{~s}^{-1}$ at $37^{\circ} \mathrm{C}$. A dissociation rate constant of $2 \mathrm{~s}^{-1}$ indicates that per second $86 \%$ of the FABP-FA complex $\left(\left.2.6 \mu \mathrm{mol} \cdot\right|^{-1}\right)$ dissociates, i.e. $\left.2.2 \mu \mathrm{mol} \cdot\right|^{-1}$ per second. From equation 6.8 a half-time value $\left(t_{v_{2}}\right)$ of $0.35 \mathrm{~s}$ can be calculated. Since the system is in equilibrium or near equilibrium, the association rate must be equal to the dissociation rate. Hence, the average residence time of one FA molecule bound to FABP can be calculated to amount to 0.7 seconds (two times $\left.t_{k}\right)$. The quotient of the unbound FA concentration $\left(\left.3.1 \mathrm{nmol} \cdot\right|^{-1}\right)$ and the association with 
FABP $\left(2.2 \mu \mathrm{mol} \cdot \mathrm{l}^{-1}\right.$ per second) reveals that the mean time a FA molecule is present in unbound form is $1.4 \cdot 10^{-3} \mathrm{~s}$ before reassociation occurs. Hence, during the entire period of diffusion, FA are present in the uncomplexed form for only $0.1 \%$ of the total time. The apparent diffusion velocity of unbound FA, however, is much higher than that of the FABPFA complex and amounts to 46-fold (quotient of $D_{F A}$ and $D_{F A B P}$ ) the diffusion velocity of the complex. From these data it can be calculated that at a FABP concentration of $170 \mu \mathrm{M}$ about $6 \%$ of the total FA translocation is caused by the uncomplexed part of the total FA pool whereas $94 \%$ is caused by FABP-FA transport. This confirms the above calculated results in which the diffusional fluxes of unbound and complexed FA were assumed to be independent. Because FA is constantly bound and released by FABP, the absolute diffusional velocity of the FA population will be higher than that of the FABP population. This phenomenon has been called the stepping-stone model (Glatz and Van der Vusse, 1990), in which a FA molecule is passed on from one FABP molecule to an adjacent one through the aqueous cytoplasm. However, since at physiological FABP concentrations the contribution of unbound FA diffusion to total FA transport is only $6 \%$, this stepping-stone model cannot play a predominant role in the total intracellular FA translocation.

An additional argument against the stepping-stone model is obtained when the average migration time in the cytoplasm is considered. The relation between the migration time and the one-directional average migration distance was derived by Einstein (1905):

$$
u=\sqrt{ }(D \cdot t)
$$

in which

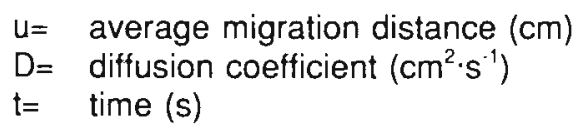

Since the average diffusional distance was assumed to be $1.5 \mu \mathrm{m}$ and the diffusion coefficient $1 \cdot 10^{-7} \mathrm{~cm}^{2} \cdot \mathrm{s}^{-1}$, it can be calculated that the time required for the FABP-FA complex to cross this distance amounts to 0.2 seconds. Hence it follows that on average a FA molecule is only bound by one FABP molecule during its translocation from the sarcolemma to the mitochondrial membrane, since the average residence time of one molecule bound to FABP was calculated to be 0.7 seconds.

Although it has been shown in the present study that FABP can have an enhancing effect on the absolute FA translocation, some reservations have to be made.

(i) It was assumed above that the average diffusional distance amounted to $1.5 \mu \mathrm{m}$. However, as already mentioned, the cardiomyocytal microanatomy reveals that an appreciable part of the mitochondria is located almost immediately adjacent to the sarcolemmal surface (subsarcolemmal mitochondria), resulting in a very short diffusional distance, whereas mitochondria are present between myofibrils as well (intramyofibrillar mitochondria). It was shown by Palmer and colleagues (1977) in vitro that intramyofibrillar mitochondria have a 1.5 fold higher fatty acid oxidation capacity than subsarcolemmal mitochondria. However, Matlib et al (1980) were not able to detect significant differences in biochemical properties of both populations in vitro and concluded that the earlier reported differences were the result of a technical artefact. 
Hence, the assumption is justified that both sub-populations of mitochondria are involved in myocardial FA oxidation. However, it can not be excluded that, despite the biochemical equivalence of these two mitochondria populations, the bulk amount of FA is utilized by subsarcolemmal mitochondria due to the limited diffusional distance to cross. In such case the necessity of FABP for intracellular FA transport is questionable. (ii) The effective outer mitochondrial membrane surface is probably overestimated in the present study, since an appreciable part of this membrane consists of protein which decreases the area available for uptake of FA in the lipid part of the membrane and the subsequent activation by acyl-CoA synthetase. Because the diffusional flux is linearly related to the magnitude of the diffusional surface (Eq. 6.1), the total physiological flux of FA (unbound FA and FABP-associated FA) will therefore be lower than calculated above.

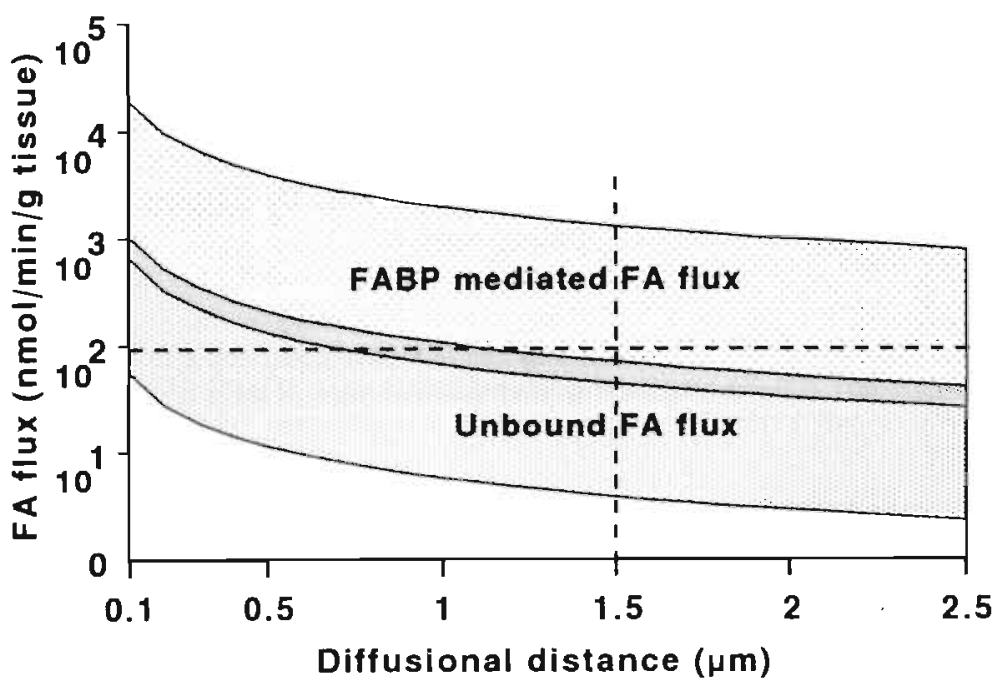

Fig. 6.5. Relation between diffusional distance and FA flux. The vertical dotted line indicates the assumed average in vivo diffusional distance whereas the dotted horizontal line depicts the basal cardiac FA oxidation level. See Discussion section for further details.

In figure 6.5 the flux of unbound FA and FABP-bound FA is depicted as a function of the diffusional distance. In addition, the flux was calculated for two extreme situations with respect to the major uncertainty factors in our calculations, i.e. (I) a situation in which the affinity of the sarcolemmal membrane for $F A$ is relatively low $\left(K_{p}=5\right)$ in combination with a maximum outer mitochondrial membrane area $\left(1.2 \mathrm{~m}^{2}\right)$ (maximal flux) and (ii) a situation in which the affinity of the sarcolemmal membrane for FA is high $\left(K_{p}=0.3\right)$ in combination with a limited outer mitochondrial membrane area $\left(0.6 \mathrm{~m}^{2}\right)$ (minimal flux). The upper area shows the FA flux mediated by FABP under these conditions, whereas the lower area shows the free FA flux. The areas show a small overlap. From these graphs it appears that at a mean diffusional distance smaller than $0.5 \mu \mathrm{m}$ the flux of unbound FA would probably be sufficient to explain the experimentally observed basal oxidation rate (horizontal dotted line). If the affinity of the sarcolemmmal membrane for FA would be low $\left(K_{p}=5\right)$ and the outer 
mitochondrial surface area maximal $\left(1.2 \mathrm{~m}^{2}\right)$ the flux of tree FA theoretically could be sufficient to ensure basal cardiac oxidation levels at an average diffusional distance up to about $1.5 \mu \mathrm{m}$. In the presence of FABP, however, much higher diffusional FA fluxes can be reached in all situations described above.

\section{Physiological significance of FABP}

The calculated values for the diffusional FA flux in cardiomyocytes obtained in this study are comparable with available experimental data concerning the in vivo uptake and utilization of FA. In isolated rat hearts, Bielefeld and co-workers (1985) measured a basal palmitate oxidation rate of $0.5 \mu \mathrm{mol} \cdot \mathrm{min}^{-1}$ per gram dry tissue. This value was confirmed by Forsey et al (1987) who measured an oleate oxidation rate of $0.4 \mu \mathrm{mol} \cdot \mathrm{min}^{-1}$ per gram dry tissue, and Lopaschuk et al (1990) who found a palmitate oxidation rate of $0.45 \mu \mathrm{mol} \cdot \mathrm{min}^{-1}$ per gram dry tissue. Conversion to wet weight tissue yields FA oxidation rates of 80,64 and $73 \mathrm{nmol} \cdot \mathrm{min}^{-1}$ per gram wet weight tissue, respectively. Since these values were measured in the isolated, unloaded heart, the in situ FA oxidation might be somewhat higher. However, in dog heart in situ a comparable value of $66 \mathrm{nmol} \cdot \mathrm{min}^{-1}$ per gram tissue was measured by Van der Vusse et al (1982). At higher workloads the blood perfusion of the heart muscle increases. Caldwell and colleagues (1990) showed that under such conditions the deposition of FA from the circulation into the tissue increases linearly at higher coronary flow rates. This results in an increase in the tissue concentration of FA and consequently in an increase in intracellular FA flux.

When the experimental results of Bielefeld and colleagues (1985), Forsey et al (1987) and Lopaschuk et al (1990) are compared with the calculated values in the present study ( $39 \mathrm{nmol} \cdot \mathrm{min}^{-1}$ per $\mathrm{g}$ tissue in the absence of FABP vs $659 \mathrm{nmol} \cdot \mathrm{min}^{-1}$ per $\mathrm{g}$ tissue in the presence of FABP for a diffusional distance of $1.5 \mu \mathrm{m}$ ) it might be concluded that a basal FA oxidation rate in rat heart of $80 \mathrm{nmol} \cdot \mathrm{min}^{-1}$ per gram tissue would not be possible in the absence of FABP, thus indicating a crucial role for FABP in the maintenance of a sufficient level of cardiac FA oxidation. Moreover, it is interesting to note that the calculated FA flux in the presence of FABP lies in the range of the maximal FA oxidation capacity of rat heart muscle, i.e. about $700 \mathrm{nmol} \cdot \mathrm{min}^{-1}$ per gram tissue (Glatz et al, 1984). However, this maximal FA oxidation level was measured in vitro in whole tissue homogenates but has to our knowledge not been measured in situ or in any isolated heart preparation.

\section{Concluding remarks}

In this chapter an attempt has been made to explain why a high concentration of FABP is present in the cardiomyocyte. It was found that FABP can enhance the rate of intracardiomyocytal transport of FA about 17 fold. In addition, experimentally observed rates of FA oxidation by rat hearts may possibly be explained only when the presence of a relatively high tissue concentration of FABP is taken into account. Nevertheless, due to the variation in several parameters involved in the present calculations on FA flux, it can not be excluded that under certain conditions or in certain cells a sufficient supply of FA in cardiac tissue can be achieved without the involvement of FABP.

\section{ACKNOWLEDGEMENT}

The authors wish to thank the following persons for kind hospitality and stimulating discussions about the presented subject: Dr. N.M. Bass and Dr. R. Weisiger, Department 
of Medicine and the Liver Centre, University of California, San Francisco CA, USA; Dr. D.P. Cistola and Dr. M. Hodsdon, Department of Biochemistry and Molecular Biophysics, Washington University School of Medicine, St. Louis MO, USA; Dr. J. Storch, Department of Nutrition, Harvard School of Public Health, Boston MA, USA.

This work was supported by the Netherlands Heart Foundation, grant no. 88.073.

\section{REFERENCES}

Anversa P, Olivetti G, Melissari M, Loud AV. 1980. Stereological measurements of cellular and subcellular hypertrophy and hyperplasia in the papillary muscle of adult rat. J Mol Cell Cardiol 12, 781-795

Bass NM. 1988. The cellular fatty acid-binding proteins: Aspects of structure, regulation and function. Int Rev Cytology 111, 143-184.

Bassingthwaighte JB, Noodleman L, Van der Vusse GJ, Glatz JFC. 1989. Modeling of palmitate transport in the heart. Mol Cell Biochem 88, 45-49.

Bielefeld DR, Vary TC, Neely JR. 1985. Inhibition of carnitine palmitoyl-CoA transferase activity and fatty acid oxidation by lactate and oxtenicine in cardiac muscle. J Mol Cell Cardiol 17, 619-625.

Bloom W, Fawcett DW. 1975. A textbook of histology. Saunders, Philadelphia, PA, USA.

Brodersen R, Skriver E, Pedersen AO. 1989. Serum albumin binding of palmitate and stearate. Multiple binding theory for insoluble ligands. Eur J Biochem 182, 19-25.

Caldwell JH, Martin GV, Link JM, Krohn KA, Bassingthwaighte JB. 1990. lodophenylpentadecanoic acidmyocardial blood flow relationship during maximal exercise with coronary occlusion. J Nucl Med 30, 99-105. Camici P, Ferrannini E, Opie LH. 1989. Myocardial metabolism in ischemic heart disease-Basic principles and application to imaging by positron emission tomography. Progress Cardiovasc Disease 22, 217-238.

De Groot MJM, Willemsen PHM, Coumans WA, Van Bilsen M, Van der Vusse GJ. 1989. Lactate induced stimulation of myocardial triacylglycerol turnover. Biochim Biophys Acta 1006, 111-115.

Dow JW, Harding NGL, Powell T. 1981. Isolated cardiac myocytes: I. Preparation of adult myocytes and their homology with the intact tissue. Cardiovasc Res 15, 483-513.

Einstein A. 1905. Ueber die von der molekularkinetischen Theorie der Wärme geforderte Bewegung von in ruhenden Flüssigkeiten suspendierender Teilchen. Ann Physik 17, 549-560.

Flck A. 1855. Ueber Diffusion. Poggendorffs Ann 94, 59-86.

Forsey RGP, Reid K, Brosnan JT. 1987. Competition between fatty acids and carbohydrate or ketone bodies as metabolic fuels for the isolated pertused heart. Can J Physiol Pharmacol 65, 401-406.

Fournier N, Geoffroy M, Deshusses J. 1978. Purification and characterization of a long-chain fatty acid binding protein supplying the mitochondrial B-oxidation system in the heart. Biochim Biophys Acta 533, $457-464$.

Glatz JFC, Jacobs AEM, Veerkamp JH. 1984. Fatty acid oxidation in human and rat heart. Comparison of cellfree and cellular systems. Biochim Biophys Acta 794, 454-465.

Glatz JFC, Van der Vusse GJ. 1990. Cellular fatty acid-binding proteins: current concepts and future directions. Mol Cell Biochem 98, 237-251.

Glatz IFC, Veerkamp JH. 1983. A radiochemical procedure for the assay of fatty acid binding by proteins. Anal Biochem 132, 89-95.

Jacobs MH. 1967. Diftusion processes. Springer-Verlag, Berlin, FRG.

Jürgens KD, Peters T, Gros G. 1990. A method to measure the diffusion coefficient of myoglobin in intact skeletal muscle cells. In Piper J (Ed): Oxygen transport to tissue XII, pp. 137-143, Plenum Press, New York, USA.

LInssen MCJG, Vork MM, De Jong YF, Glatz JFC, Van der Vusse GJ. 1990. Fatty acid oxidation capacity and fatty acid-binding protein content of different cell types isolated from rat heart. Mol Cell Biochem 98, 19-25. Lopaschuk GD, Spafford MA, Davies NJ, Wall SR. 1990. Glucose and palmitate oxidation in isolated working rat hearts reperfused after a period of transient global ischemia. Circ Res 66, 546-553. Matarese V, Stone RL, Waggoner DW. Bernlohr DA. 1989. Intracellular fatty acid trafficking and the role of cytosolic lipid binding proteins. Prog Lipid Res 28, 245-272.

Matlib MA, Rebman D, Ashraf M, Rouslin W, Schwatz A. 1981. Differential activities of putative subsarcolemmal and interfibrillar mitochondria from cardiac muscle. J Mol Cell Cardiol 13, $163-170$.

McCormack M, Brecher P. 1987. Effect of liver fatty acid-binding protein on fatty acid movement between liposomes and rat liver microsomes. Biochem J 244, 717-723.

Moll W. 1968. The diffusion coefficient of myoglobin in muscle homogenate. Pflügers Arch 299, $247-251$. 
Noy N, Donnelly TM, Zakim D. 1986. Physical-chemical model for the entry of water-insoluble compounds into cells. Studies of farty acid uptake by the liver. Biochemistry 25, 2013-2021.

Ockner RK, Manning JA, Poppenhausen R, Ho W. 1972. A binding protein for fatty acids in cytosol of intestinal mucosa, liver, myocardium and other tissues. Science 177, 56-58.

Offner GD, Troxler RF, Brecher P. 1986. Characterization of a fatty acid-binding protein from rat heart. J Biol Chem 261, 5584-5589.

Page E, McCallister LP. 1973. Quantitative electron microscopic description of heart muscle cells. Application to normal, hypertrophied and thyroxin-stimulated hearts. Am J Cardiol 31, 172-181.

Palmer JW, Tandler B, Hoppel CL. 1977. Biochemical properties of subsarcolemmal and interfibrillar mitochondria from cardiac muscle. J Biol Chem 252, 8731-8739.

Paulussen RJA, van der Logt CPE, Veerkamp JH. 1988. Characterization and binding properties of fatty acidbinding proteins from human, pig and rat heart. Arch Biochem Biophys 264, 533-545.

Peeters RA, Veerkamp JH, Demel RA. 1989. Are fatty acid-binding proteins involved in fatty acid transfer ? Biochim Biophys Acta 1002, 8-13.

Riveros-Moreno V, Wittenberg JB. 1972. The self-diffusion coefficients of myoglobin and haemoglobin in concentrated solutions. J Biol Chem 247, 895-901.

Rothschild MA, Oratz M, Schreiber SS. 1988. Serum albumin. Hepatology 8, 385-401

Stewart JM, Driedzic WR, Berkelaar JAM. 1991. Fatty acid-binding protein facilitates the diffusion of oleate in a model cytosol system. Biochem J 275, 569-573.

Storch J, Bass NM. 1990. Transfer of fluorescent fatty acids from liver and heart fatty acid-binding protein 10 model membranes. J Biol Chem 265, 7827-7831.

Storch J, Kleinfeld AM. 1986. Transfer of long-chain fluorescent fatty acids between unilamellar vesicles. Biochemistry 25, 1717-1726.

Tipping E, Ketterer B. 1981. The influence of soluble binding proteins on lipophile transport and metabolism in hepatocytes. Biochem J 195, 441-452.

Underberg C. Börchers T, Hфjrup P, Roepstortf P, Knudsen J, Spener F. 1990. Cardiac fatty acid-binding proteins: Isolation and characterization of the mitochondrial fatty acid-binding protein and its structura! relationship with the cytosolic isoforms. J Biol Chem 265, 16255-16261.

Van der Vusse GJ, Glatz JFC, Stam HCG, Reneman RS. 1992. Fatty acid homeostasis in the normoxic and ischemic heart. Physiol Rev 72, 881-940.

Van der Vusse GJ, Roemen THM, Prinzen FW, Coumans WA, Reneman RS. 1982. Uptake and tissue content of fatty acids in dog myocardium under normoxic and ischemic conditions. Circ Res 50, 538-546.

Van Bilsen M, Van der Vusse GJ, Willemsen PHM, Coumans WA, Roemen THM, Reneman RS. 1989. Lipid alterations in isolated, working heart during ischemia and reperfusion: Its relation to myocardial damage. Circ Res 64, 304-314.

Van Holde KE. 1971. Physical Biochemistry. Prentice-Hall Inc., Englewood Clifs, New Jersey, USA

Veerkamp JH, Peeters RA, Maatman RGHJ. 1991. Structural and functional features of different types of cytoplasmic fatty acid-binding proteins. Biochim Biophys Acta 1081, 1-24.

Vork MM, Glatz JFC, Surtel DAM, Van der Vusse GJ. 1990. Assay of the binding of fatty acids by proteins: evaluation of the Lipidex 1000 procedure. Mol Cell Biochem 98, 111-117.

Vork MM, Glatz JFC, Surtel DAM, Knubben HJM, Van der Vusse GJ. 1991a. A sandwich enzyme linked immuno-sorbent assay for the determination of rat heart fatty acid-binding protein using the streptavidin-biotin system. Application to tissue and effluent samples from normoxic rat heart perfusion. Biochim Biophys Acta 1075, 199-205.

Vork MM, Glatz JFC, Van der Vusse GJ. 1991b. Does fatty acid-binding protein facilitate the diffusion of oleic acid? Biochem J 280, 835.

Waggoner DW, Bernlohr DA. 1990. In situ labeling of the adipocyte lipid binding protein with 3-['25|]lodo-4- $N$ hexadecylsalicylamine. J Biol Chem 265, 11417-11420.

Wojcieszyn JW, Schlegel RA, Wu E, Jacobson KA. 1981. Diffusion of injected macromolecules within the cytoplasm of living cells. Proc Nat Acad Sci USA 78, 4407-4410. 


\section{CHAPTER 7}

\section{PROTEIN RELEASE FROM ISOLATED RAT HEART DURING NORMOXIA, LOW-FLOW ISCHEMIA AND REPERFUSION.}

Michaël M. Vork, Jan F.C. Glatz, Don A.M. Surtel and Ger J. Van der Vusse. 


\section{SUMMARY}

The present study was performed to monitor the effect of low-flow ischemia and reperfusion on changes in the protein permeability of the cardiomyocyte cell membrane and the endothelial cell layer. The dependence of the release of intracellular proteins on their physico-chemical properties was also studied. To this end, isolated rat hearts were perfused according to Langendorff, with separate collection of vascular and interstitial effluents. The release patterns of two proteins differing substantially in molecular mass, i.e. fatty acidbinding protein (FABP; $15 \mathrm{kDa}$ ) and lactate dehydrogenase ( $\mathrm{LDH} ; 130 \mathrm{kDa}$ ), were determined. Control hearts were perfused normoxically for 300 minutes, whereas experimental hearts were subjected to 60 minutes normoxia, 180 minutes low-flow ischemia ( $1 \mathrm{ml} / \mathrm{min}$ per gram tissue) and finally 60 minutes normoxic reperfusion. During the first 240 minutes of perfusion $0.2 \%$ of total tissue FABP and $1.1 \%$ of total tissue LDH were detected in the effluents in both groups. Moreover, in each case $80 \%$ of released FABP and LDH was found in the interstitial effluent. During 60 minutes of reperfusion, following 180 minutes of low-flow ischemia in the experimental group, appreciable amounts of both proteins were released $(2.2 \%$ and $5.1 \%$ of total tissue contents for FABP and $L D H$, respectively). During this period a significant increase in the percentual amount of protein released in the vascular effluent was found for both proteins. It is concluded that the combination of low-flow ischemia and reperfusion increases the protein permeability of both the cardiomyocyte cell membrane and the endothelial barrier. Since the release patterns of FABP and LDH in time were similar during the entire perfusion protocol, it is tempting to state that protein release from tissue is an aspecific effect of a noxious intervention. However, because the release of LDH was 6-fold higher during low-flow ischemia and 2-3 fold higher during reperfusion than that of FABP, it is most likely that protein release from tissue depends on a number of physico-chemical properties of both the protein and the (intra)cellular environment.

\section{INTRODUCTION}

When cardiac tissue becomes deprived of oxygen and nutrients for a period of time, i.e. as a result of coronary artery occlusion, intracellular constituents will leak out of the cells and can be detected in blood (LaDue et al, 1954). Leakage has been suggested to be caused by the appearance of pores in the cellular membrane (De Leiris and Hearse, 1984). The only way to prevent the tissue from irreversible damage is to restore cardiac flow to normal levels in due time. However, restoration of flow in cardiac tissue after a prolonged period of ischemia appears to result in additional damage. Although this phenomenon of reperfusion damage has been known for several decades, its primary cause is still not completely elucidated (Hearse, 1977; Poole-Wilson, 1987; Opie, 1989; Kehrer and Starnes, 1989). The initial events for reperfusion damage are probably the influx of calcium (Jennings and Shen, 1972) and the enhanced formation of oxygen derived free radicals in the tissue (Bolli et al, 1989) in combination with a significant ischemia-induced loss of anti-oxidant activity (Guarnieri et al, 1980). Calcium influx is thought to cause mechanical disruption of cell membranes due to hypercontraction (Ganote and Kaltenbach, 1979). On the other hand, it has been suggested that changes in intracellular osmotic pressure and cell volume on reperfusion may give rise to cell swelling and subsequent cell membrane rupture (Jennings et al, 1986). Enhanced oxygen free radical formation can cause membrane lipid peroxidation (Guarnieri, 1980) which, in turn, may lead to an increased membrane permeability for calcium to enter and for proteins to leave the cell. In this context ultrastructural changes at 
the level of the cell membrane have been reported (Post et al. 1985; Schrijvers et al, 1990).

Many investigators have monitored protein release from isolated heart during reperfusion, mostly after a period of global zero-flow ischemia (for review see Kehrer and Starnes, 1989). Therefore, little is known on the release of intracellular proteins during the ischemic period, simply because during zero-flow ischemia effluent sampling is not possible. On the other hand, the low-flow model has more clinical relevance than the zero-flow model, since in cardiac disease it is commonly observed that parts of the myocardium become gradually deprived of oxygen and nutrients as a result of slow forming coronary stenosis (Opie, 1991). Furthermore, with regard to low-flow ischemia and reperfusion, information is lacking on possible changes in permeability of the capillary wall, especially in relation to the physico-chemical properties of proteins released from myocardial cells. Studying this model might increase the knowledge of the mechanism of protein release from the injured myocardium to the extracellular environment.

Therefore, the aim of the present study was to monitor protein release in detail during a prolonged period of low-flow ischemia followed by normoxic reperfusion. To this end an isolated rat heart perfusion model was chosen in which low-flow ischemia was applied. The release from damaged cells of two cytoplasmic proteins differing in molecular mass, i.e. fatty acid-binding protein (FABP, $15 \mathrm{kDa}$ ) and lactate dehydrogenase (LDH, $130 \mathrm{kDa}$ ), was assayed in the perfusion effluent. Effluent was collected in two fractions, i.e. interstitial and vascular fluid. Since the cellular location FABP is almost exclusively cardiomyocytal (Linssen et al, 1990), distribution of this protein between interstitial and vascular fluids will give information about endothelial protein permeability.

\section{MATERIALS AND METHODS}

\section{Isolated rat heart preparation and perfusion}

Hearts from male Lewis rats $(250-325 \mathrm{~g})$ were used in all experiments. The hearts were Langendorff perfused with a buffer, continuously gassed with $95 \% \mathrm{O}_{2}$ and $5 \% \mathrm{CO}_{2}$, containing (in $\mathrm{mM}$ ) NaCl (132), $\mathrm{KCl}(4.7), \mathrm{CaCl}_{2}$ (1.3), $\mathrm{MgCl}_{2}(1.0), \mathrm{NaH}_{2} \mathrm{PO}_{4}$ (0.4), $\mathrm{NaHCO}_{3}$ (20) and glucose (11) $\left(\mathrm{pH} 7.35 \pm 0.03, \mathrm{~T}=37^{\circ} \mathrm{C}, \mathrm{p}=8.0 \mathrm{kPa}\right)$, and prepared according to $\mathrm{De}$ Deckere and Ten Hoor (1977) in order to allow separate collection of right ventricular effluent $\left(Q_{n}\right)$, fluid draining the coronary vessels, and interstitial $\left(Q_{i}\right)$ effluents (Figure 7.1). The preparation of the hearts took $20-25$ minutes.

\section{Experimental protocol}

Isolated hearts (wet weight $0.97 \pm 0.07 \mathrm{~g}$ ) were subjected to 60 minutes of normoxic perfusion followed by 180 minutes of low-flow perfusion at $1 \mathrm{ml} / \mathrm{min}$ per $\mathrm{g}$ tissue (approximate 7 fold reduction of flow) and subsequent normoxic reperfusion for 60 minutes $(n=9)$. Control hearts $(n=6)$ were perfused normoxically for 300 minutes (Figure 7.2). Effluent samples were collected during 15 min intervals and flow was calculated from these fractions. Bovine serum albumin in a final concentration of $1-2 \%$ was added to each sample so as to prevent protein loss and reduction of enzymatic activity during storage. The samples were stored at $-80^{\circ} \mathrm{C}$ until analyses of FABP and $\mathrm{LDH}$, which were performed as described in Chapter 4 (Vork et al, 1991; Bergmeyer and Bernt, 1974).

In a separate series of experiments two sets of three hearts were used to microscopically monitor tissue perfusion after either 240 minutes of normoxia, or 60 minutes 
normoxia followed by 180 minutes of low-flow ischemia ( $t=240$ minutes in Figure 7.2). For this the hearts were perfused with $100 \mu$ perfusion buffer containing $1 \%$ acridine orange. This dye is rapidly taken up by the nucleus of endothelial cells and can be visualized using fluorescence light-microscopy (Tangelder et al, 1982; Peeze Binkhorst, 1989). Special precautions were taken to avoid flow alterations during dye perfusion. After 5 minutes the hearts were frozen by entirely submerging in liquid $\mathrm{N}_{2}$-cooled isopentane. Thereafter, $5 \mu \mathrm{m}$ ventricular tissue sections were cut transversally at $-20^{\circ} \mathrm{C}$ and subsequently monitored for the distribution of the dye.

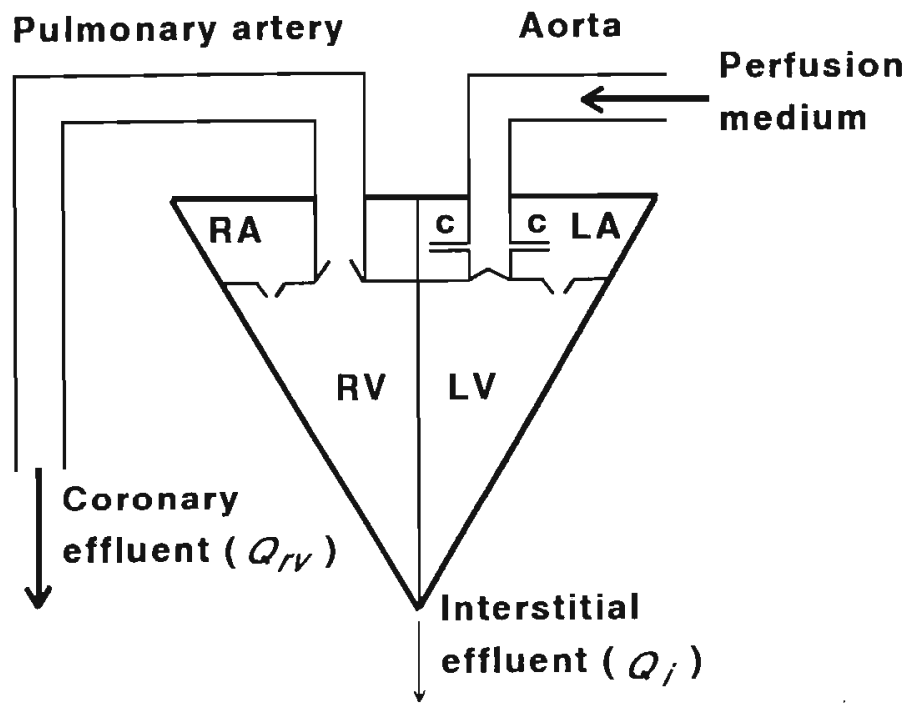

Fig. 7.1. Schematic representation of an isolated rat heart perfusion model with separate collection of right ventricular $\left(Q_{n}\right)$ and interstitial $\left(Q_{i}\right)$ effluents. RA, right atrium; LA, left atrium; RV, right ventricle; $L V$, left ventricle; c, coronary artery.
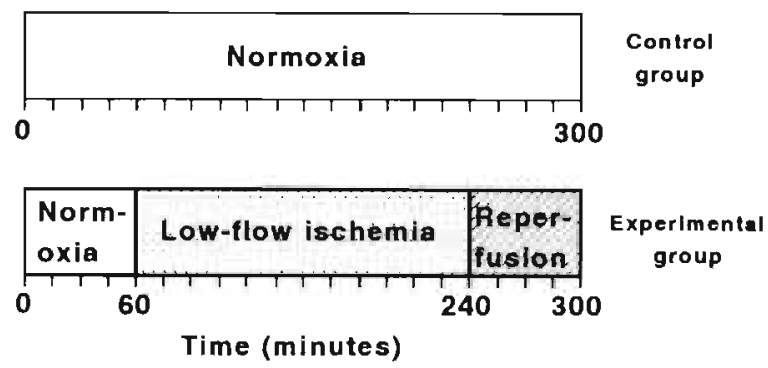

Fig. 7.2. Experimental protocol. Bars indicate sampling times (15 minutes per sample). 


\section{Chemicals}

All chemicals were purchased from either Sigma (St. Louis, USA) or Merck (Darmstadt, FRG) and were of analytical grade.

\section{Statistical treatment of data}

Results in the figures and tables are expressed as mean values \pm S.E.M. At each sampling point controls and experimental hearts were compared using Student's $t$-test for all parameters measured, unless indicated otherwise. Differences were regarded significant at $p<0.05$.

\section{RESULTS}

Upon attachment to the perfusion system, all hearts started contracting within 15 seconds. The initial interstitial flow never exceeded $2 \%$ of total flow, similar to reports by others (Stam and Hülsmann, 1981), but lower than the mean value of $3.2 \%$ reported in the original description of the perfusion system (De Deckere and Ten Hoor, 1977). During the low-flow ischemic period the contraction rate of the experimental hearts decreased appreciably. During normoxic reperfusion the contraction rate increased again and short periods ( $<5 s$ ) of fibrillation could be observed.

\section{Flow measurements}

During normoxia the vascular flow $\left(Q_{r v}\right)$ decreased gradually during 300 minutes of normoxic perfusion (Figure 7.3, upper panel). This decrease reached the level of significance at $\mathrm{t}=135 \mathrm{~min}$, as compared with the initial flow. The absolute interstitial flow $\left(Q_{i}\right)$ remained constant during 300 minutes of normoxic perfusion (Figure 7.3, middle panel). Due to the decrease in absolute $Q_{n}$ flow, the percentual $Q_{i}$ flow increased from $0.8 \%$ to $1.3 \%$ of total flow (Figure 7.3, lower panel).

Following one hour of normoxic perfusion in the experimental group the $Q_{N}$ flow was kept at $1 \mathrm{ml} / \mathrm{min}$ for 180 minutes. Upon normoxic reperfusion the $Q_{r}$ flow immediately returned to its initial value (Figure 7.3, upper panel). However, the subsequent decrease in flow ( $40 \%$ in 60 minutes) turned out to be more rapid than during the initial normoxic period (13\% in 60 minutes). Furthermore, during the low-flow ischemic period the $Q_{i}$ flow increased gradually in time (significant at $t=150$; Figure 7.3 , middle panel) and reached a final value of about $15 \%$ of total flow (Figure 7.3 , lower panel). Upon normoxic reperfusion the $Q$, flow did not return to its initial value as was the case for $Q_{r}$, but remained at the percentual level measured at the end of the ischemic period, resulting in a more than 10 fold increase in absolute $Q_{i}$ flow.

\section{Protein release}

The absolute release of the two proteins under investigation is depicted in Figure 7.4, in which a discrimination is made between protein release in $Q_{N}$ (left panels) and $Q_{i}$ (right panels). The release patterns of the two proteins are essentially identical. During low-flow ischemia their release into both fractions increased slightly, but not significantly starting from $t=180$ minutes to $t=240$ minutes in comparison with the control perfusion. During normoxic reperfusion a far greater amount of intracellular protein was released into the effluents. 


\begin{tabular}{lllll} 
& & & 3 & \% release in $Q$, effluent \\
\cline { 5 - 5 } $\begin{array}{llll}\text { Time } \\
\text { (min) }\end{array}$ & Group & $n$ (animals) & FABP & LDH \\
\hline \multirow{2}{*}{0.60} & Co-N & $24(6)$ & $84 \pm 1$ & $80 \pm 2$ \\
& Exp-N & $36(9)$ & $79 \pm 1^{\circ}$ & $83 \pm 3$ \\
$60-240$ & Co-N & $70(6)$ & $80 \pm 1$ & $79 \pm 2$ \\
& Exp-LF & $103(9)$ & $78 \pm 1$ & $81 \pm 1$ \\
$240-300$ & Co-N & $24(6)$ & $82 \pm 1$. & $80 \pm 3$ \\
& Exp-Rep & $32(9)$ & $68 \pm 2$ & $64 \pm 3^{\circ}$ \\
\hline
\end{tabular}

Table 7.1. Release of LDH and FABP in $Q$, effluent as a percentage of total release. N, normoxia; LF, lowflow ischemia; Rep, reperfusion; Co, control group; Exp, experimental group. Mean $\pm S E M$ (for the indicated number of observations, $n)$. "significantly different from control group $(p<0.05)$.

\begin{tabular}{|c|c|c|c|c|c|}
\hline \multirow[b]{2}{*}{$\begin{array}{l}\text { Time } \\
\text { (min) }\end{array}$} & \multirow[b]{2}{*}{ Group } & \multirow[b]{2}{*}{$\mathrm{n}$ (animals) } & \multicolumn{3}{|c|}{$\begin{array}{l}\% \text { release per minute of } \\
\text { total tissue content }\end{array}$} \\
\hline & & & $\begin{array}{c}\text { FABP } \\
\left(\times 10^{3}\right) \\
a\end{array}$ & $\begin{array}{l}\text { LDH } \\
\left(\times 10^{3}\right) \\
b\end{array}$ & $\begin{array}{l}\text { Ratio } \\
\text { b/a }\end{array}$ \\
\hline \multirow[t]{2}{*}{0.60} & Co-N & $24(6)$ & $1.23 \pm 0.06$ & $7.4 \pm 0.6$ & $6.0 \pm 0.4$ \\
\hline & Exp-N & $36(9)$ & $1.09 \pm 0.08$ & $6.1 \pm 0.4$ & $6.1 \pm 0.1$ \\
\hline \multirow[t]{2}{*}{$60-240$} & Co-N & $70(6)$ & $0.72+0.02$ & $3.7 \pm 0.1$ & $5.3 \pm 0.2$ \\
\hline & Exp-LF & $103(9)$ & $0.81 \pm 0.07$ & $3.7 \pm 0.2$ & $5.9 \pm 0.2$ \\
\hline \multirow[t]{2}{*}{$240-300$} & Co-N & $24(6)$ & $0.74 \pm 0.06$ & $3.4 \pm 0.2$ & $4.8 \pm 0.2$ \\
\hline & Exp-Rep & $32(9)$ & $37 \pm 7^{\circ}$ & $85 \pm 14^{\circ}$ & $2.9 \pm 0.2$ \\
\hline
\end{tabular}

Table 7.2. Average release of FABP and LDH from tissue and the ratio of these values, expressed as a percentage of total tissue content per minute. For explanation of abbreviations see legend to Table 7.1. MeantSEM (for the indicated numbers of observations, $n$ ). significantly different from control group ( $p<0.05)$.

Since effluent was collected in two fractions, the absolute distribution of released proteins between interstitial and vascular effluents could be calculated (Table 7.1). For FABP it was found that the percentual amount measured in $Q_{i}$ differed significantly between the control and experimental groups during the first 60 minutes of the experiment and during reperfusion, but not during low-flow ischemia. For LDH a difference was found only during the reperfusion period (Table 7.1). As observed earlier (Vork et al, 1991), a discrepancy between the total LDH and FABP release in relation to their total tissue content was found during normoxic perfusion. In the present study this discrepancy was also observed during the low-flow ischemic period and the reperfusion period. From each sample, the percentual release of both proteins was calculated in terms of total tissue content $(0.74 \mathrm{mg} / \mathrm{g}$ and 314 $\mathrm{U} / \mathrm{g}$ wet tissue for FABP and $\mathrm{LDH}$, respectively; Vork et al, 1991). These release percentages as well as the quotient of these values are given in Table 7.2. Approximately $1.3 \%$ of total tissue LDH content was released during five hours normoxia whereas for FABP only $0.24 \%$ of total tissue content was found during this period. The control group as well as the experimental group showed a decreasing tendency of the LDH/FABP ratio within the 
course of each experiments. However, during reperfusion this ratio was significantly lower in the experimental group than in the control group (Table 7.2). During this period an average of $2.2 \%(\mathrm{FABP})$ and $5.1 \%(\mathrm{LDH})$ of total tissue content was released.
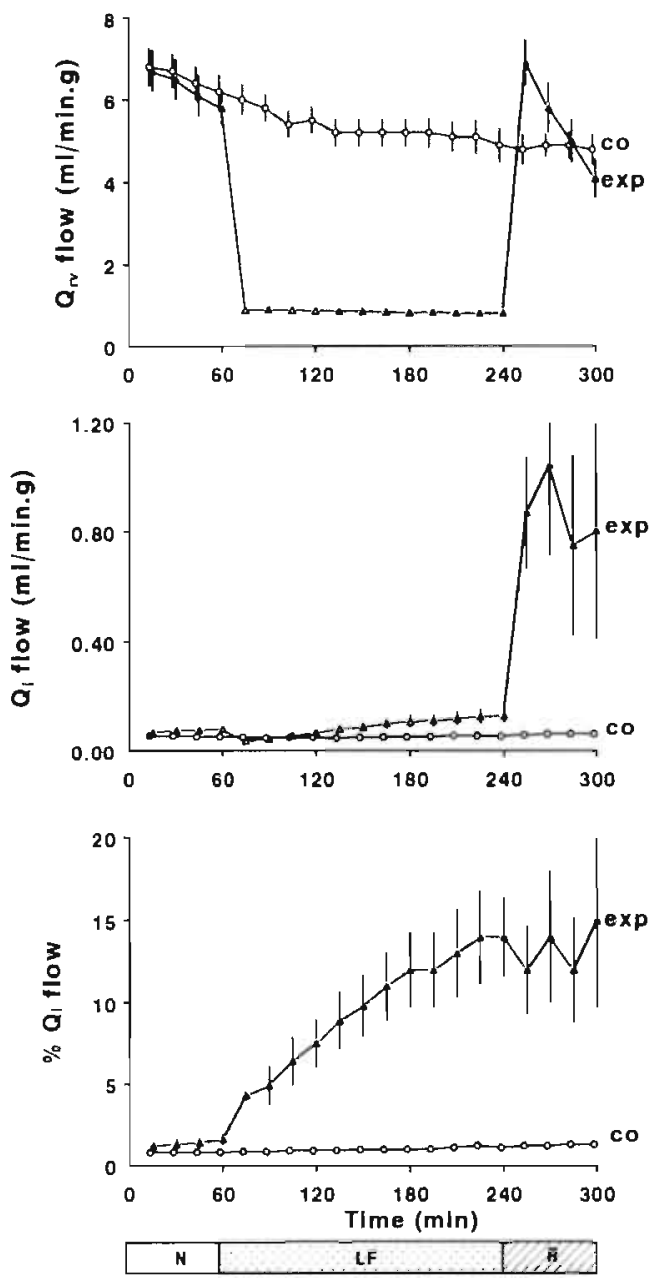

Fig. 7.3. Coronary flow characteristics during the course of the experiments. Upper panel: right ventricular flow, middle panel: interstitial flow, lower panel: percentual interstitial flow. Note the difference in $Y$-axis scale between $Q_{r v}$ and $Q_{i}$ Co, control hearts $(n=6)$; Exp, experimental hearts $(n=9)$. N, normoxia; $L F$, low-flow ischemia; $R$, reperfusion.

\section{Tissue perfusion}

Tissue sections prepared after 240 minutes of normoxic perfusion or 60 minutes of normoxia followed by 180 minutes of low-flow perfusion were judged qualitatively for the deposition of acridine orange (Figure 7.5). Three hearts, perfused normoxically for 4 hours, showed an almost homogeneous distribution of the dye. However, hearts perfused 
normoxically for one hour and subsequently with a flow of $1 \mathrm{ml} / \mathrm{min}$ for another three hours showed large differences in dye distribution. In all hearts the outer tissue layer was stained with the dye whereas in the inner layers hardly any fluorescence was observed.
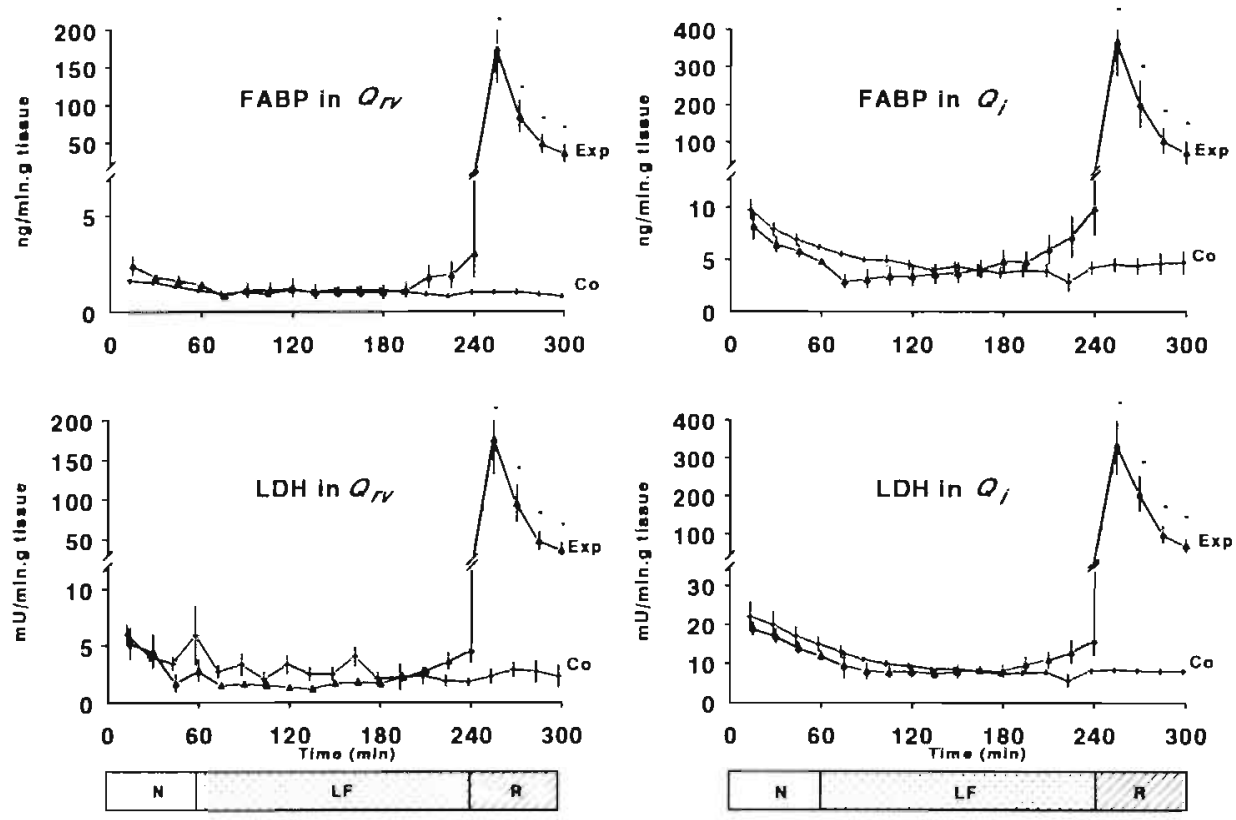

Fig. 7.4. Release patterns of FABP and LDH from isolated rat hearts. Co,control hearts; Exp, experimental hearts. Note the difference in $Y$-axis scale between $Q_{n}$ (left panels) and $Q_{i}$ (right panels). N,LF and $\mathrm{R}$ refer to normoxia, low-flow ischemia and reperfusion, respectively.' significantly different from control group $(\rho<0.05)$

\section{DISCUSSION}

The present study describes the changes in vascular and interstitial flow and the release of proteins during normoxia, low-flow ischemia and reperfusion for isolated rat heart. The contribution of interstitial flow to total cardiac flow increased substantially during low-flow ischemia and reperfusion. During 180 minutes low-flow ischemia no increase in protein release could be detected as compared with normoxic perfusion, whereas an appreciable release was observed upon reperfusion. The release patterns of the two proteins under investigation were essentially similar.

\section{Interstitial flow}

During normoxic perfusion of rat heart it was observed that in the control group the interstitial flow $\left(Q_{i}\right)$ remained remarkably constant over the total perfusion period. In contrast, in the experimental group the $Q_{i}$ flow increased rapidly during low-flow ischemia. This finding can be explained by a net water flux increase from the vasculature to the interstitial space. In this respect earlier findings from Harris and colleagues (1978) are worth to mention. They found that in the dog a reduction of cardiac flow increases the endothelial permeability for 
sucrose. This increase in permeability is most likely caused by ischemia induced endothelial alterations. Endothelial cells have been shown to be vulnerable for ischemic damage (Hülsmann and Dubelaar, 1987). Upon an increase in the permeability surface area, the flux of solutes, present in the perfusion buffer, from the vascular space to the interstitial space will increase. This increase is most likely accompanied by an enhanced water transport, which might explain the gradual increase in interstitial flow. Furthermore, an increase in the concentration of small solutes, released from cardiomyocytes as a result of the ischemic insult, may also contribute on an increase of the flux of water from the vascular to the interstitial space.

Since the increase in absolute $Q_{i}$ flow during low-flow ischemia was gradual, it might be concluded that the extent of ischemic endothelial damage depends on the duration of the ischemic period. Moreover, since $Q_{i}$ flow did not return to its initial value upon normoxic reperfusion, the increase in endothelial permeability most likely is irreversible.

\section{Myocardial flow}

At the end of the low-flow ischemic period it was found that only the outer layer (subepicardium) of the ventricular tissue could be stained with an endothelial nucleus marker (Figure 7.5). This finding indicates that the inner layers where no longer perfused at the end of the low-flow ischemic period. A similar observation was reported by Harris et al (1978) who found that in the dog heart flow restriction resulted in a decrease in the endothelial surface area caused by capillary derecruitment in the dog. However, in the present study it was also found that the $Q_{i}$ flow increased appreciably during low-flow ischemia, indicating that the permeability surface area must have increased even more in the tissue areas which were perfused during the entire period of low-flow ischemia, i.e. the subepicardial regions. Upon reperfusion under normal perfusion pressure no significant decrease in coronary flow could be observed compared with the pre-ischemic flow rate, suggesting that at this pressure the entire coronary vasculature might have been perfused again. Complete reperfusion of previously un(der)perfused regions is in contrast with the findings of Mohanlal et al (1988) who found that after a 2 hour period of low-flow ischemia ( $20 \%$ of pre-ischemic flow) the flow rate returned to only $60 \%$ of the pre-ischemic value, as a result of the socalled no-reflow phenomenon (Gavin et al, 1983). However, these investigators used a paced heart model in combination with a water-filled balloon inserted in the left ventricular cavity together with a high pyruvate concentration in the perfusion medium. The combination of differences in the experimental setup might explain the deviations in the outcome of the two studies.

\section{Protein release}

During a period of 180 minutes of low-flow ischemia, the released amounts of proteins were not different from those during a similar normoxic perfusion period, but upon subsequent normoxic reperfusion an appreciable amount of cytoplasmic proteins was released from the tissue. However, as discussed above, no indication for irreversible tissue damage was observed during the preceding low-flow ischemic period on the basis of protein release.

The subendocardial layers of the ventricles were no longer accessible for the perfusion fluid after 180 minutes of low-flow ischemia. The redistribution of flow in hypo-perfused tissue is most likely a chronic process in which more and more tissue becomes deprived of perfusion medium. However, as no significant increase in protein release was observed 

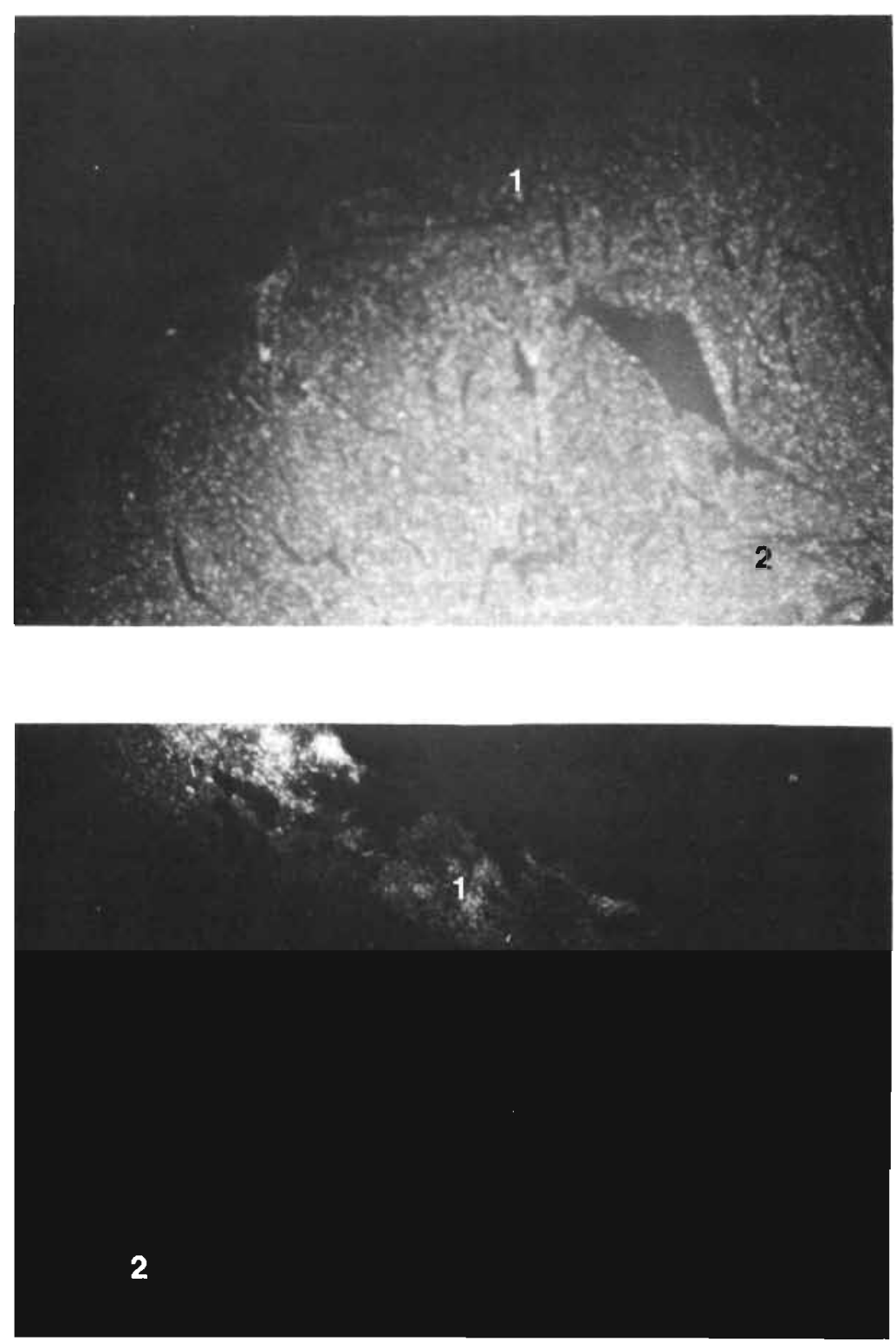

Fig. 7.5. Deposition of acridine orange in ventricular tissue. Upper panel, 240 minutes normoxic perfusion. Lower panel, 60 minutes normoxic perfusion followed by 180 minutes of low-flow ischemia (1 $\mathrm{ml} / \mathrm{min}$ per $\mathrm{g}$ tissue). 1 and 2 indicate subepicardial and subendocardial tissue layers, respectively. 
during low-flow ischemia it might be possible that none or very little tissue damage occurred during this period and that the main trigger for protein release was reperfusion per se. On the other hand, cell deterioration might already have occurred during low-flow ischemia, in particular in regions completely devoid of flow, whereby released proteins were not able to diffuse fast enough into a perfused tissue area to be detected in the effluents. This explanation has to be considered since rat heart virtually lacks collateral vessels (Maxwell et $\mathrm{al}, 1987$ ). Hence, with the results of the present study, no definite conclusions can be drawn about the primary cause of protein release during reperfusion, as it may be caused by either ischemia induced damage or reperfusion injury.

\section{Endothelial permeability for proteins}

During reperfusion a significant increase in the percentual amount of protein released in $Q_{n}$ was found, when compared with the normoxic control. The distribution of perfusate between $Q_{r}$ and $Q_{i}$ at the onset of reperfusion was not different from that at the end of the low-flow ischemic period $\left(Q_{i}\right.$ flow approximately $15 \%$ of total flow; Figure 7.3., lower panel). Therefore, this observation indicates an increased endothelial permeability for proteins, especially from the interstitial space to the vascular space, since FABP is almost exclusively located in the cardiomyocyte (Linssen et al, 1990). Moreover, this increase in permeability was similar for both $F A B P$ and $L D H$, suggesting that these two proteins were released from the same (cardiomyocytal) space and that LDH release from endothelial cells was negligible in comparison with release from cardiomyocytes.

\section{Discrepancy between FABP and LDH release}

During normoxia and low-flow ischemia LDH, despite its higher molecular mass, was found to be released approximately 6-fold more than FABP, when expressed as a percentage of the total tissue content. This was already observed in an earlier study (Chapter 4; Vork et al, 1991). However, this release ratio altered significantly upon reperfusion (Table 7.2). As stated in Chapter 4 it might be possible that this discrepancy in protein release is caused by the fact that FABP is almost entirely present in cardiomyocytes (Linssen et al, 1990), whereas LDH can be found also in other cardiac cell types, such as endothelial cells and fibroblasts. However, from data of Anversa and colleagues (1980) it can be calculated that the cellular volume in cardiac tissue occupied by endothelial cells and fibroblasts amounts to $3.2 \%$ and $1.8 \%$, respectively, whereas cardiomyocytes occupy $78 \%$ of the total tissue volume. Furthermore, the LDH contents of isolated endothelial cells and fibroblasts each were found to be approximately $1.4 \mathrm{U} / \mathrm{mg}$ total protein and that of isolated cardiomyocytes to be $2.5 \mathrm{U} / \mathrm{mg}$ (Y.F. de Jong and M.C.J.G. Linssen, unpublished data). Hence, it is unlikely that the measured LDH/FABP release ratio is caused solely by the presence of LDH in cell types other than cardiomyocytes, especially since the release patterns of the two proteins were similar as discussed above.

The discrepancy in the observed amounts of released LDH and FABP might be explained by differences in iso-electric point (IEP) between the two proteins. FABP has an IEP of approximately 5 (Fournier et al, 1978), whereas for rabbit LDH a value between 8.3 and 8.6 has been reported (Susor et al, 1969). Hence, at physiological pH FABP has a fairly high negative charge whereas LDH has a slight positive charge. This may cause FABP to be bound to a greater extent to intracellular structures than is LDH. During low-flow ischemia the $\mathrm{pH}$ of the un(der)perfused tissue regions is likely to decrease as a result to metabolic changes in the tissue (Dennis et al, 1990). The electrical charge of FABP then would 
diminish, resulting in a less tight electrical interaction with intracellular structures, whereas that of LDH would increase, leading to a decrease in the LDH/FABP release ratio of these proteins. In this respect, several observations that 'cytoplasmic' proteins are weakly bound to a large extent to intracellular structures have been reported, e.g. moderate protein release from cells after solubilisation of the cellular membrane (Schliwa et al, 1981) and remarkable low diffusion coefficients for proteins in the cytoplasm (Gershon et al, 1985). Gershon and colleagues indicated that the cytoplasm of the cell has a gel-like structure comprising of a three-dimensional network, called the microtrabecular lattice. It might be possible that, due to this lattice, large protein molecules have a smaller intracellular space through which they can penetrate than smaller ones, comparable to gels used for gel-permeation chromatography. In that case, the released amounts of relatively high molecular mass proteins would be higher when membrane permeability increases than that of smaller proteins. This then might be another explanation for the discrepancy of LDH and FABP release observed in the present study.

\section{Concluding remarks}

In conclusion it can be stated that the results of the present study indicate that protein release from isolated rat heart during low-flow ischemia and reperfusion is a complex process. Further research is needed to elucidate the precise mechanism of protein release from ischemic myocardium. These further investigations might include ( $I$ ) monitoring the release of other proteins from the cardiomyocyte, in order to assess if the hypothesis of the influence of the molecular mass and the iso-electric point on release from cells is applicable to those proteins, (ii) enhancement of the low-flow ischemic time to monitor if, at that situation, a significant increase of protein release can be observed between the experimental group and the control group during this period, (iii) gradual instead of instant restoration of normal coronary flow after the low-flow ischemic period to determine if the occurrence of tissue damage is related to the sudden increase in vascular pressure, and (iv) perfusion under permanent maximal vasodilatation, so as to ensure that the total vascular space is perfused during the entire period of low-flow ischemia.

\section{ACKNOWLEDGEMENT}

This study was supported by the Netherlands Heart Foundation, grant number 88.073 .

\section{REFERENCES}

Anversa P, Olivetti G, Melissari M, Loud AV. 1980. Stereological measurements of cellular and subcellular hypertrophy and hyperplasia in the papillary muscle of adult rat. J Mol Cell Cardiol 12, 781-795.

Bolli J, Jeroudi MO, Patel BS, Aruoma OI, Halliwell B, Lai EK, McCay PB. 1989. Marked reduction of free radical generation and contractile dysfunction by anti-oxidant therapy begun at the time of reperfusion: evidence that myocardial "stunning" is a manifestation of reperfusion injury. Circ Res 65, 607-622.

Bergmeyer HU, Bernt E. 1974. In: Methods of enzymatic analysis. Vol.2 (Bergmeyer HU, ed.) pp. 574-579, Verlag Chemie GmbH, Weinberg, FRG.

Dennis SC, Gevers W, Opie LH. 1991. Protons in ischemia: Where do they come from; where do they go to. $\mathrm{J}$ Mol Cell Cardiol 23, 1077-1086.

De Deckere EAM and Ten Hoor P. 1977. A modified Langendorff technique for metabolic investigations. Plügers Arch 370, 103-105.

De Leiris J, Hearse DJ. 1984. Myocardial enzyme leakage as an indicator of cellular injury: principles and application. In: Methods in studying cardiac membranes. Ed. N. Dhalla. Chapter 17. CRC press, Boca Raton FL, USA. 
Fournier NC, Geoffrey M, Deshusses J. 1978. Purification and characterization of a long-chain fatty acid binding protein supplying the mitochondrial B-oxidation in the heart. Biochim Biophys Acta 533, 457-464.

Ganote CF and Kaltenbach JP. 1979. Oxygen-induced enzyme release: early everts and a proposed mechanism. J Mol Cell Cardiol 11, 389-406.

Gavin JB, Humphrey SM, Herdson PB. 1983. The no-reflow phenomenon in ischemic myocardium. Int Rev Exp Pathol 25, 361-383.

Gershon ND, Porter KR, Trus BL. 1985. The cytoplasmic matrix: Its volume and surface area and the diffusion of molecules through it. Proc Nat Acad Sci USA 82, 5030-5034.

Guarnieri C, Flamigni F and Caldarera CM. 1980. Role of oxygen in the cellular damage induced by reoxygenation of hypoxic heart. $J$ Mol Cell Cardiol 12, 797-808.

Harris TR, Gervin CA, Burks D, Custer P. 1978. Effects of coronary flow reduction on capillary-myocardial exchange in dogs. Am J Physiol 234, H679-H689.

Hearse DH. 1977. Reperfusion of the ischemic myocardium. J Mol Cell Cardiol 9, 605-616.

Hülsmann WC, Dubelaar ML. 1987. Early damage of vascular endothelium during cardiac ischemia. Cardiovasc Res 21, 674-677.

Jennings RB, Shen AC. 1972. Calcium in experimental myocardial ischemia. In: Bajusz E and Rona G (Ed.), Recent advances in studies on cardiac structure and metabolism. Baltimore, University park press, pp 639-655. Jennings RB, Reimer KA and Steenbergen C. 1986. Myocardial ischemia revisited. The osmolar load, membrane damage and reperfusion. J Mol Cell Cardiol 18, 769-780.

Kehrer JP and Starnes JW. 1989. Models and markers used to study cardiac reperfusion injury. Pharmac Ther 44, 123-145.

LaDue JS, Wróblewski F and Karmen A. 1954. Serum glutamic oxaloacetic transaminase activity in human acute transmural myocardial infarction. Science 120, 497-499.

Linssen MCJG, Vork MM, De Jong YF, Glatz JFC, Van der Vusse GJ. 1990. Fatty acid oxidation capaclty and fatty acid-binding protein content of different cell types isolated from rat heart. Mol Cell Biochem 98, 19-25.

Maxwell MP, Hearse DJ, Yellon DM. 1987. Species variation in the coronary collateral circulation during regional myocardial ischemia: a critical determinant of the rate of evolution and extent of myocardial infarction. Cardiovasc Res 21, 737-746.

Mohanlal RW, Mauve I, Zoet ACM, Van der Laarse A. 1988. Reperfusion induced enzyme release: washout effect or manifestation of reperfusion damage? Cardiovasc Res 22, 603-610.

Opie LH. 1989. Reperfusion injury and its pharmacologic modification. Circulation 80, 1049-1062.

Opie LH. 1991. The heart: Physiology and metabolism, 2nd ed. chapter 17, Raven press, New York, USA.

Peeze Binkhorst F. 1989. Morphometric and microcirculatory aspects of muscle use and overuse. Ph.D. thesis University of Limburg, Maastricht, The Netherlands.

Poole-Wilson PA. 1987. Reperfusion damage in the heart muscle: still unexplained but with new clinical relevance. Clin Physiol 7, 439-453.

Post JA, Leunissen-Bijvelt J, Ruigrok TJC and Verkleij AJ. 1985. Ultrastructural changes of sarcolemma and mitochondria in the isolated rabbit heart during ischemia and reperfusion. Biochim Biophys Acta 845, 119-123. Stam H, Hülsmann WC. 1981. Release of lipolytic products from rat heart. Hormonal stimulation, intracardiac origin and pharmacological modification. Biochem Int 2, 477-484.

Schrijvers AHGJ, De Groot MJM, Heijnen VVTh, Van der Vusse GJ, Frederiks PM and Reneman RS. 1990. Ischemia and reperfusion induced multilammmelar vesicles in isolated rabbit heart: time correlation between morphometric data and metabolic alterations. J Mol Cell Cardiol 22, 653-665.

Schliwa M, Van Blerkom J, Porter KR. 1981. Stabilisation of the cytoplasmic ground substance in detergentopened cells and a structural and biochemical analysis of its composition. Proc Nat Acad Sci USA 78, 4329. 4333.

Susor WA, Kochman M, Rutter WJ. 1969. Heterogeneity of presumably homogeneous protein preparations. Science 165, 1260-1262.

Tangelder GJ, Slaaf DW, Reneman RS. 1982. Fluorescent labeling of blood platelets in vivo. Thromb Res 28, 803-820.

Vork MM, Glatz JFC, Surtel DAM, Knubben HJM and Van der Vusse GJ. 1991. A sandwich enzyme linked immuno-sorbent assay for the determination of rat heart fatty acid-binding protein using the streptavidin-biotin system. Application to tissue and effluent samples from normoxic rat heart perfusion. Biochim Biophys Acta 1075, 199-205. 
CHAPTER 8

\section{RELEASE OF FATTY ACID-BINDING PROTEIN AND LONG CHAIN FATTY ACIDS FROM ISOLATED RAT HEART AFTER ISCHEMIA AND SUBSEQUENT CALCIUM PARADOX*}

Michaël M. Vork, Jan F.C. Glatz and Ger J. Van der Vusse

Mol Cell Biochem, in press, 1993. 


\section{SUMMARY}

To obtain insight into the relation between the release of heart-type fatty acid-binding protein (FABP) and of long-chain fatty acids (FA) from injured cardiac tissue, rat hearts were Langendorff perfused according to the following scheme: 30 min normoxia, 60 min ischemia, 30 min reperfusion, $10 \mathrm{~min} \mathrm{Ca}^{2+}$ free perfusion and finally $10 \mathrm{~min} \mathrm{Ca}^{2+}$ readmission. During this protocol right ventricular $\left(Q_{n}\right)$ and interstitial effluent samples $\left(Q_{j}\right)$ were collected at regular intervals. During reperfusion a total of $0.8 \pm 0.1 \mathrm{nmol} F A B P$ but no FA were detected in the effluents. However, during $\mathrm{Ca}^{2+}$ readmission, $45 \pm 4$ nmol FABP $(80-90 \%$ of total tissue content) was released with an initial (first $3 \mathrm{~min}$ ) simultaneous release of FA (FAVABP ratio $0.90 \pm 0.07 \mathrm{~mol} / \mathrm{mol}$ ). Thereafter, FA release continued at $10-15 \mathrm{nmol}$ per min mainly in $Q_{v}$ while the rate of FABP release decreased. During $\mathrm{Ca}^{2+}$ readmission, tissue FA content raised rapidly from $168 \pm 20$ to $1918 \pm 107 \mathrm{nmol} / \mathrm{g}$ dry weight. These findings suggest that after severe cardiac damage initially FA is released bound to FABP, whereas further FA release occurs in a non-protein bound manner.

\section{INTRODUCTION}

Under patho-physiological conditions, such as prolonged ischemia, the intramyocardial long chain fatty acid (FA) content is known to rise in the heart (Van der Vusse et al, 1987; Van der Vusse et al, 1992). Among other FA, enhanced cellular levels of arachidonic acid are found. Since this fatty acid is almost exclusively incorporated in the phospholipid pool, this finding indicates hydrolysis of phospholipids. During subsequent reperfusion the increase in tissue FA content continues (Van Bilsen et al, 1989). In isolated rat hearts FA accumulation also occurs during a 10 minute perfusion with a medium lacking $\mathrm{Ca}^{2+}$ as well as during the subsequent readmission of $\mathrm{Ca}^{2+}$ (Van der Vusse et al, 1988), a protocol causing the so-called calcium paradox (Zimmerman and Hülsmann, 1966). Readmission of $\mathrm{Ca}^{2+}$ results in massive tissue damage, probably mediated primarily by a large influx of $\mathrm{Ca}^{2+}$ ions into the cardiomyocytes and the subsequent hypercontraction of myofibrils (Ganote et al, 1983). High concentrations of FA in the heart are thought to cause various pathological phenomena, e.g. instabilisation and subsequent rupture of cellular membranes and inhibition of a number of enzymes (Katz and Messineo, 1981; Katz, 1982; Van der Vusse et al, 1992).

The heart contains an appreciable amount (Vork et al, 1991) of a small protein (15 $\mathrm{kDa}$ ) that can bind FA, and is referred to as cytoplasmic fatty acid-binding protein, FABP (Bass, 1988; Matarese et al, 1989; Glatz and Van der Vusse, 1990; Kaikaus, 1990; Veerkamp et al, 1991). FABP is located almost exclusively in cardiomyocytes where it exhibits a concentration of $4.5 \mu \mathrm{g} / \mathrm{mg}$ tissue protein, as measured immunochemically in isolated cells (Linssen et al, 1990). The FABP concentrations in isolated endothelial cells and fibroblasts each were found to be approximately 1000 fold lower (Linssen et al, 1990). It has been postulated by Brecher (1983) and later by Glatz and colleagues (1985) that, besides its putative transport function, FABP might play a role in the binding of accumulated FA during ischemia, thus keeping the amount of intracellular unbound FA to a low non-toxic level. Srimani and colleagues (1990) suggested that rat hearts, pre-perfused with FABP containing liposomes, had a better resistance to subsequent ischemia and concluded that the enhanced ischemia tolerance could be related to an increased intracellular concentration of FABP in the cardiomyocytes. However, the validity of this study was seriously doubted as changes in intracellular FABP content were not demonstrated (Glatz et al, 1991).

It is unknown at which cellular site FA accumulation occurs in the heart during ischemia 
and reperfusion (Van der Vusse et al, 1992). The putative FA scavenging function of FABP requires that FA accumulation takes place mostly in the cardiomyocyte. Accumulation of FA mainly in endothelial cells and/or fibroblasts would make the FA scavenging function of the protein highly unlikely.

At present it is unclear whether loss of intracellular protein following irreversible cellular damage is associated with a concomitant release of fatty acids. FABP was found to be released from injured isolated rat hearts but a simultaneous release of FA could not be detected (Glatz et al, 1988). If FA are bound to FABP in vivo, which is likely to occur (Waggoner and Bernlohr, 1990; Waggoner et al, 1991), it might be expected that these substances are released simultaneously from injured cardiac tissue, especially when before release they are located in the same tissue compartment.

Therefore, the aims of the present study were $(i)$ to investigate the release of FA in combination with the loss of FABP from injured rat hearts, and (ii) to gain better insight in the question from which tissue compartment FA release occurs. To this end, isolated rat hearts were perfused according to Langendorff (1895) with separate collection of right ventricular (vascular) effluent $\left(Q_{r v}\right)$ and interstitial effluent $\left(Q_{i}\right)$ (De Deckere and Ten Hoor, 1977). The hearts were successively subjected to zero-flow ischemia, reperfusion and the calcium paradox. This protocol was chosen to induce high levels of FA in cardiac tissue (Van Bilsen, 1989) and to discriminate between release of substances from the vascular wall and the parenchymal tissue. Furthermore, the calcium paradox was applied to quickly release the cytoplasmic constituents.

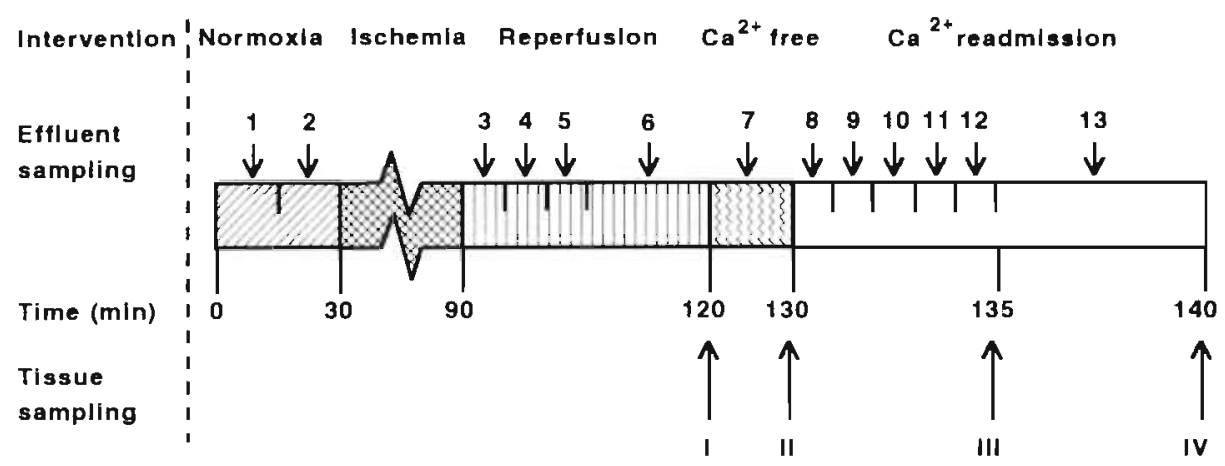

Fig. 8.1. Schematic representation of the experimental protocol. Upper arrows indicate eflluent sampling, lower arrows indicate tissue sampling. Effluent samples were taken during normoxia (two 15 minutes samples, for flow measurements only, $n=17$ ), reperfusion (three 5 minutes samples and one 15 minutes sample, $\mathrm{n}=17$ ), $\mathrm{Ca}^{2+}$ depletion (one 10 minutes sample, $\mathrm{n}=13$ ), and $\mathrm{Ca}^{2+}$ readmission (five 1 minute samples and one 5 minutes sample, $n=5$ ).

\section{MATERIALS AND METHODS}

\section{Experimental protocol}

Hearts were perfused similar as described in chapter 7 (Figure 7.1.) and subjected to the perfusion scheme depicted in Figure 8.1. After 30 minutes of normoxic perfusion, during which two flow measurements were made (sample 1 and 2), perfusion was completely stopped for 60 minutes (ischemia). Thereafter, flow was restored under the same initial 
conditions for 30 minutes (reperfusion). During this period three 5 minutes samples and one 15 minutes sample of the perfusate were taken (samples 3 to 6 ) for the determinations of protein and FA release and of coronary and interstitial flow. Subsequently, the hearts were perfused with the same buffer but lacking $\mathrm{CaCl}_{2}$ for 10 minutes $\left(\mathrm{Ca}^{2+}\right.$ free, sample 7). Finally, $\mathrm{CaCl}_{2}$ was re-introduced in the buffer and effluent samples were collected at five 1 minute intervals and one 5 minutes interval $\left(\mathrm{Ca}^{2+}\right.$ readmission, samples 8 to 13). At four time points hearts were quickly frozen with the use of aluminum tongues cooled in liquid $\mathrm{N}_{2}$ (Figure 8.1).

\section{Rat heart perfusion}

Adult male Lewis rats $(320-410 \mathrm{~g}$, average heart wet weight $1.2 \mathrm{~g})$ were mildly anaesthetized with diethylether after which the hearts were rapidly removed and immediately placed in ice cold perfusion buffer containing (in $\mathrm{mM}$ ) $\mathrm{NaCl}$ (132), $\mathrm{KCl}(4.7), \mathrm{CaCl}_{2}(1.3)$, $\mathrm{MgCl}_{2}(1.0), \mathrm{NaH}_{2} \mathrm{PO}_{4}(0.4), \mathrm{NaHCO}_{3}(20)$, glucose (11) and pyruvate (5) (pH 7.32-7.39). The aorta was prepared free and the hearts were connected to the perfusion system via the aorta. Immediately thereafter perfusion according to Langendortf was started $\left(T=37^{\circ} \mathrm{C}, \mathrm{p}=8.0\right.$ $\mathrm{kPa}$ ) with the above described buffer, which was continuously gassed with $95 \% \mathrm{O}_{2}$ and $5 \%$ $\mathrm{CO}_{2}$. The hearts then were further prepared according to De Deckere and Ten Hoor (1977). Total preparation of the hearts took 20-25 minutes. Following collection of $Q_{r v}$ and $Q_{j}$ effluent samples the flow was determined by weighing the sample and correcting for the specific mass of the perfusion buffer. Thereafter $100 \mu \mathrm{l}$ of an essentially fatty acid-free bovine serum albumin solution $(200 \mathrm{~g} / \mathrm{l})$ was mixed with $1 \mathrm{ml}$ of sample, in order to avoid protein and FA loss during storage. Finally the samples were frozen in liquid $\mathrm{N}_{2}$ and stored at $-80^{\circ} \mathrm{C}$ until analysis. At the end of each experiment the heart was rapidly removed from the perfusion system, freeze-clamped and also stored at $-80^{\circ} \mathrm{C}$ until analysis.

\section{Assay of FABP and fatty acids}

All chemicals used were purchased either from Merck (Darmstadt, FRG) or Sigma (St. Louis, MO, USA), unless indicated otherwise, and were of analytical grade. Albumin was checked for FA content by extracting FA from albumin solutions according to Folch and colleagues (1957) and subsequent gaschromatographic analysis (Van der Vusse et al, 1982). The FA content turned out to amount to $10 \mathrm{nmol} / \mathrm{g}$ albumin (molar FA:albumin ratio 1:1500). FABP in tissue and effluent samples was assessed with the immunological method described in chapter 4 (Vork et al, 1991). Fatty acids in tissue and effluent samples were extracted according to Folch et al (1957) and subsequently determined using a HPLC technique as described by Roemen and Van der Vusse (1991), which is approximately 50 fold more sensitive than gaschromatographic procedures (Van der Vusse et al, 1982) and does not require separation of lipid classes before FA assessment. For the lipid extraction from effluent samples 10 parts of thawed sample were mixed with 1 part of HEPES buffer $(0.1 \mathrm{M}, \mathrm{pH}=7.0)$ at $0^{\circ} \mathrm{C}$. It was found that $\mathrm{FA}$ were poorly recovered during the Folch extraction when this neutralisation step was omitted (data not shown). Incomplete recovery was probably due to the relatively high $\mathrm{pH}$ value of the samples after thawing $(\mathrm{pH}=10)$. A perfusion buffer sample treated similar as effluent samples served as a blanc for the determination of FA in effluents. 


\section{Statistical treatment of data}

Values are expressed as mean \pm SEM. Student's $t$-test was used to detect differences between the experimental groups. Differences were regarded significant at $p<0.05$. The total number of hearts for each group is indicated in the text.

\section{RESULTS}

During the course of the experiment it was visually observed that hearts almost immediately started beating after connection to the aortic cannula. On the onset of ischemia, contraction force increased initially but had stopped completely after 5-10 minutes. Upon reperfusion, contraction resumed within 1 minute, although occasionally fibrillation occurred at the onset of reperfusion. However, sinus rhythm was usually restored spontaneously within 5 minutes as judged visually. Perfusion with a medium lacking $\mathrm{Ca}^{2+}$ caused cessation of contraction within 15 seconds. Subsequent readmission of $\mathrm{Ca}^{2+}$ caused a rapid massive tissue damage as observed by the colour change of the tissue in combination with red coloured $Q_{r}$ and $Q_{i}$ effluents.
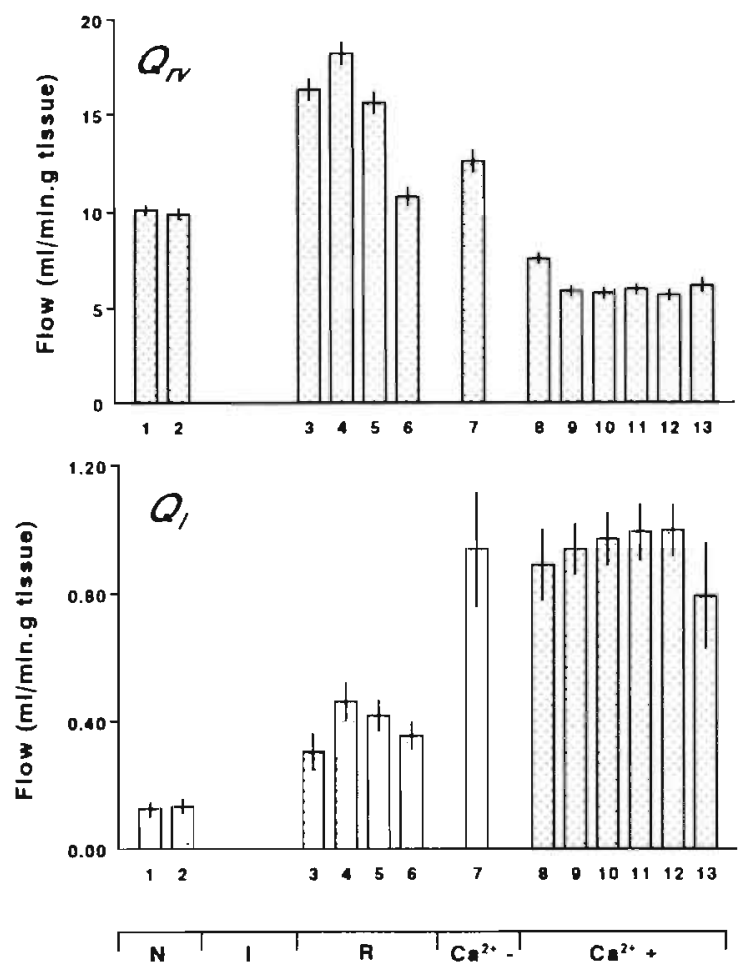

Fig. 8.2. Cardiac flow during the experimental protocol. $Q_{r}$ and $Q_{i}$ are shown in the upper and lower panel, respectively. Initially $Q_{i}$ flow was $1 \%$ of total flow. 


\section{Flow measurements and tissue water content}

Figure 8.2. shows the course of the $Q_{n}$ (upper panel) and $Q_{i}$ (lower panel) flow during the experimental protocol. During reperfusion after 60 minutes of ischemia, both $Q_{r v}$ and $Q_{i}$ were significantly higher as compared to the pre-ischemic period, a phenomenon known as hyperaemia. However, $Q_{r}$ returned to its initial value after 30 minutes reperfusion. Although $Q_{i}$ showed a comparable pattern during repertusion as compared with $Q_{r}$ it remained significantly higher compared with the pre-ischemic value $(0.13 \pm 0.02 \mathrm{ml} / \mathrm{min}$ per $\mathrm{g}$ vs. $0.36 \pm 0.05 \mathrm{ml} / \mathrm{min}$ per $\mathrm{g}$ (19 measurements for both values) for pre- and post-ischemia respectively, $\rho<0.01)$. Tissue dry weight was significantly lower than during normoxia, indicating an approximate $10 \%$ increase in total weight (Table 8.1). Introduction of the $\mathrm{Ca}^{2+}$ free buffer caused a slight but significant increase in $Q_{N}$ whereas a sudden dramatic increase in $Q_{i}(0.36 \pm 0.05 \mathrm{ml} / \mathrm{min}$ per $\mathrm{g}$ (19 measurements) vs. $0.94 \pm 0.50 \mathrm{~m} / \mathrm{min}$ per g (14 measurements), $p<0.01$ ) was observed. Tissue dry weight did not change during this period (Table 8.1). Finally, on $\mathrm{Ca}^{2+}$ readmission $Q_{r v}$ dropped below the initial pre-ischemic value $(10.1 \pm 0.3 \mathrm{ml} / \mathrm{min}$ per $\mathrm{g}(\mathrm{n}=14)$ vs. $7.6 \pm 0.3 \mathrm{ml} / \mathrm{min}$ per $\mathrm{g}(n=5), p<0.01)$ without a change in $Q$. Furthermore, tissue dry weight was appreciably decreased already after five minutes of $\mathrm{Ca}^{2+}$ readmission (Table 8.1 ), most likely caused by huge edema formation in combination with loss of intracellular compounds.

\begin{tabular}{|c|c|c|}
\hline \multirow{2}{*}{$\begin{array}{l}\text { Intervention } \\
10 \text { min normoxia }\end{array}$} & \multicolumn{2}{|c|}{$\begin{array}{l}\% \text { dry weight } \\
\text { (MeantSEM) }\end{array}$} \\
\hline & $16.0 \pm 0.7$ & $(n=15)$ \\
\hline 30 min reperfusion & $14.4 \pm 0.8^{\circ}$ & $(n=4)$ \\
\hline 10 min $\mathrm{Ca}^{2 *}$ depletion & $13.8 \pm 0.9^{\circ}$ & $(n=4)$ \\
\hline $5 \mathrm{~min} \mathrm{Ca}^{2 *}$ readmission & $9.6 \pm 0.8^{\prime \prime}$ & $(n=5)$ \\
\hline 10 min $\mathrm{Ca}^{2 *}$ readmission & $9.7 \pm 0.8^{*}$ & $(n=4)$ \\
\hline
\end{tabular}

Table B.1. Tissue dry weight during the course of the experiments. Tissue dry weight was assessed at the end of each intervention. Significantly lower compared to normoxia," significantly lower compared to normoxia, reperfusion and $\mathrm{Ca}^{2+}$ depletion.

\section{FA accumulation in tissue}

Figure 8.3 depicts the alterations in tissue FA content during the course of the experiments. After ischemia and subsequent reperfusion the total tissue content was measured to amount to $168 \pm 20 \mathrm{nmol} / \mathrm{g}$ dry weight which corresponds with $24 \pm 3 \mathrm{nmol} / \mathrm{g}$ wet weight $(n=4)$, a value comparable with those of normoxically perfused rat hearts (De Groot et al, 1989). $\mathrm{Ca}^{2+}$ depletion had no effect on cardiac FA content either $(167 \pm 30 \mathrm{nmol} / \mathrm{g}$ dry weight, $\mathrm{n}=4$ ). Upon readmission of $\mathrm{Ca}^{2+}$, tissue $\mathrm{FA}$ content raised rapidly to $1177 \pm 54 \mathrm{nmol} / \mathrm{g}$ dry weight after 5 minutes $(n=5)$ and $1918 \pm 107 \mathrm{nmol} / \mathrm{g}$ dry weight $(n=4)$ after 10 minutes. The pattern of individual accumulating FA, such as palmitic acid (C16:0), palmitoleic acid (C16:1), stearic acid (C18:0), oleic acid (C18:1), linoleic acid (C18:2), arachidonic acid (C20:4) and docosahexaenoic acid (C22:6) was comparable to that found by Van der Vusse and co-workers (1988). 


\section{FABP release from tissue}

During the reperfusion period only $1-2 \%$ of the total tissue contents of FABP $(0.8 \pm 0.1$ $\mathrm{nmol} / \mathrm{g}$ tissue $(\mathrm{n}=19))$ was released from the hearts. The bulk amount of this $(79 \pm 2 \%)$ was found in $Q_{i}$. On the average the concentration in $Q_{i}$ turned out to be 160 fold higher than in $Q_{r v}$ Upon $\mathrm{Ca}^{2+}$ readmission, however, large amounts of FABP were found in both $Q_{r v}$ and $Q_{i}$ as shown in Figure 8.4 (upper panel). Total release in 10 minutes amounted to $83 \pm 9 \%$ of total tissue content. The release of lactate dehydrogenase, an enzyme present in the cytoplasm of cardiomyocytes and in other cardiac cell types displayed essentially the same release pattern (data not shown). The concentration of FABP was 2 fold higher in $Q_{i}$ than in $Q_{r v}$ during the first minute, but increased gradually to approximately a 6 -fold higher value after 10 minutes of $\mathrm{Ca}^{2+}$ readmission.

\section{FA release from tissue}

After reperfusion and subsequent perfusion in the absence of $\mathrm{Ca}^{2+}$, no detectable amounts of FA were released from the hearts. However, at $\mathrm{Ca}^{2+}$ readmission FA was detected in both $Q_{n}$ and $Q_{i}$, with an initial $80 \%$ of total release in $Q_{r v}$ (Figure 8.4, middle panel). This percentage then decreased to $60 \%$ after 3 minutes but again increased to a final value of $95 \%$ after 10 minutes of $\mathrm{Ca}^{2+}$ readmission. The distribution of the individual FA in the effluents are depicted in Figure 8.5 for $Q_{n}$ (upper panel) and $Q_{i}$ (lower panel), respectively. A marked difference in the contents of $C 18: 2$ and $C 20: 4$ was observed between the two effluent fractions. The percentual contribution of these individual FA were higher in $Q_{i}$ than in $Q_{r}$ Furthermore, in both $Q_{N}$ and $Q_{i}$ release of C18:0 showed an increasing tendency during $\mathrm{Ca}^{2+}$ readmission, whereas the percentual contribution of $\mathrm{C} 18: 1$ decreased gradually during this period.

Interestingly, an initial simultaneous release of FABP and FA could be observed (Figure 8.4 , lower panel) in a FA/FABP molar ratio of $0.9 \pm 0.07 \mathrm{~mol} / \mathrm{mol}$ in both $Q_{r}$ and $Q_{i}$ during the first three minutes. Thereafter, in $Q_{n}$ the molar ratio increased dramatically to a final value of $23 \mathrm{~mol} \mathrm{FA} / \mathrm{mol}$ FABP after 10 minutes, whereas in $Q_{i}$ this ratio increased only slightly to $1.7 \mathrm{~mol} / \mathrm{mol}$.

\section{DISCUSSION}

Definite proof on the physiological function(s) of the FABPs in general and specifically of FABP in the heart is lacking. However, several putative functions of the protein have been put forward, e.g. an unbound FA buffering function (Brecher, 1983; Glatz et al, 1985).

In the present study we have tried to gain more insight into the processes which take place upon the occurrence of tissue damage in the isolated ischemic rat heart, especially in respect to alterations in lipid homeostasis. The major finding is that upon large tissue damage induced by the calcium paradox after a period of ischemia the release of FA is initially paralleled by an almost equimolar release of $F A B P$, possibly indicating that $F A$ are indeed released from the tissue bound to FABP. This and the other observations will be discussed in detail below.

\section{Flow measurements and tissue water content}

Large alterations in cardiac flow characteristics could be observed during various stages of the experimental period. Firstly, during reperfusion the total flow increased initially 
but returned to normal values within 30 minutes. However, $Q_{i}$ remained significantly higher as compared to the pre-ischemic period. During ischemia damage of endothelium occurs, as was judged by endothelial-borne protein release after ischemia (Hülsmann and Dubelaar, 1987). Although not indicated by the authors, damage may be accompanied by enhanced endothelial permeability for certain substances, e.g. glucose which is present at a concentration of $11 \mathrm{mM}$ in the perfusion medium and for which a muscular endothelial permeability of 0.6 (relative to water with a value 1) has been reported (Guyton, 1991; Crohn and Levitt, 1984). An increase in net flux of such small compounds from vasculature to interstitium will be accompanied by an increased net flux of water, thus increasing the interstitial pressure resulting in an enhanced interstitial flow. Secondly, on $\mathrm{Ca}^{2+}$ depletion during 10 minutes the interstitial flow further increased greatly, possibly caused by a further increase in capillary permeability for relatively small substances. Finally, at $\mathrm{Ca}^{2+}$ readmission the permeability of all substances must be regarded to be similar to that of water or small substances since the permeability of macromolecules like proteins was found to be dramatically increased at that time interval.

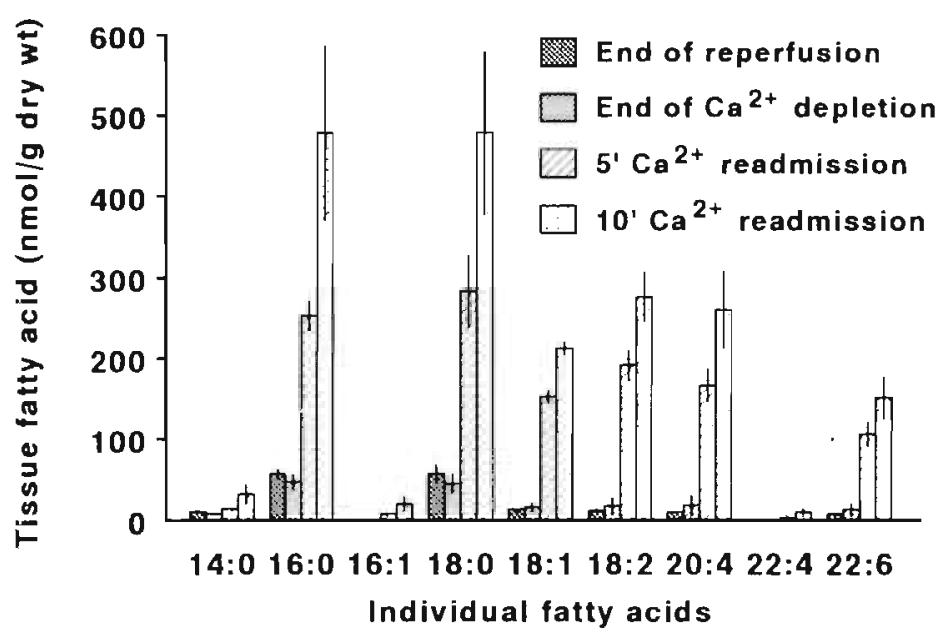

Fig. 8.3. Accumulation of individual FA in tissue during the experimental protocol. Results are MeantSEM ( $n=4$ or 5 , see Table 8.1 ) C14:0=myristic acid, C16:0=palmitic acid, C16:1=palmitoic acid, C18:0=stearic acid, C18:1=oleic acid, C18:2=linoleic acid, C20:4=arachidonic acid, $\mathrm{C} 22: 4=$ docosatetraenoic acid, C22:6=docosahexaenoic acid.

\section{Protein release and endothelial damage}

Hülsmann and Dubelaar (1987) reported a high endothelial vulnerability for ischemic damage. They found that after 60 minutes of no-flow ischemic conditions endothelial specific enzymes (i.e. xanthine oxidase and xanthine dehydrogenase) could be monitored in both $Q_{N}$ and $Q_{i}$ In the present study it was found that during reperfusion after 60 minutes of ischemia, $1-2 \%$ of the total tissue FABP amount was released from the hearts, a value comparable to the release of lactate dehydrogenase as reported by Van Bilsen and coworkers (1991) after 45 minutes of ischemia. Moreover, the amount of FABP found in $Q_{i}$ amounted to $80 \%$ of the total release, a value similar to results previously reported during normoxic perfusion of isolated rat hearts (Vork et al, 1991). Therefore it is concluded that, 
although endothelial damage occurs upon ischemia, the protein permeability of the endothelial barrier is not enhanced. No increase in protein release was observed during the period of $\mathrm{Ca}^{2+}$ depletion. During $\mathrm{Ca}^{2+}$ readmission a fast and almost complete FABP release from tissue occurred $\left(89 \%\right.$ of the total tissue protein content during 10 minutes $\mathrm{Ca}^{2+}$ readmission), mainly in $Q_{n}$. Protein concentration differences between $Q_{i}$ and $Q_{n}$ were initially only a factor 2 but gradually increased to a factor 6 . From this observation it might be concluded that, even after severe tissue damage, the endothelium is capable of restoring its barrier function partially. Nevertheless it should be mentioned that, despite this apparent functional recovery, the permeability remains rather high in comparison with the normoxic permeability.

\section{FA accumulation in tissue}

In the present study an increase in tissue FA content after ischemia and subsequent reperfusion could not be detected. This was a surprising finding since it is well documented in other experimental models that after such a treatment FA content of cardiac tissue increases, particularly in the presence of pyruvate as exogenous substrate (Van Bilsen et al, 1989; Van Bilsen et al, 1991). However, in the present study the hearts were perfused according to Langendorff whereas Van Bilsen and colleagues $(1989 ; 1991)$ used a working heart model. Moreover, in the present study a lower $\mathrm{Ca}^{2+}$ concentration in the perfusion buffer was used (1.3 mM vs. $2.5 \mathrm{mM}$ ). Neely and Grotyohann (1984) found that the functional recovery of ischemic cardiac tissue depends on the $\mathrm{Ca}^{2+}$ concentration of the perfusion medium. A relatively low $\mathrm{Ca}^{2+}$ concentration $(1.25 \mathrm{mM})$ resulted in complete functional recovery after 60 minutes of ischemia, whereas in the presence of $2.5 \mathrm{mM} \mathrm{Ca}^{2+}$ recovery was measured to amount to only $13 \%$ as compared with the pre-ischemic function. The combination of these two differences in perfusion protocol might explain the absence of FA accumulation in the present study. Nevertheless, the fast FA accumulation observed during $\mathrm{Ca}^{2+}$ readmission is in agreement with earlier findings of Van der Vusse et al (1988).

\section{FA release from tissue}

In earlier studies of our group (Glatz et al, 1988; Van der Vusse et al, 1988; Glatz and Van der Vusse, 1989) in one set of experiments isolated rat hearts were subjected to 60 minutes of ischemia, followed by reperfusion, whereas another set of isolated rat hearts were subjected to the calcium paradox. Surprisingly, no FA loss was detected during reperfusion, which caused an FABP loss equal to approximately $3 \%$ of total tissue content, whereas only minute amounts of FA were measured in effluents collected during the calcium paradox experiments and in which an appreciable amount of FABP was released. It was therefore concluded from these experimental findings that the postulated scavenging function of FABP is questionable. However, the absence of FA in the effluent samples might be explained by the fact that at that time effluent samples were not collected and stored in an albumin containing medium. It was found in a later study that diluted solutions of protein and FA can give rise to appreciable losses of these substances (Chapter 3; Vork et al, 1990), as a result of aspecific sticking of FABP and FA to the storage vessel wall.

In the present study a significant FA release from isolated rat heart was observed. During $\mathrm{Ca}^{2+}$ readmission a more or less fixed FAFABP release ratio $(0.90 \pm 0.07 \mathrm{~mol} / \mathrm{mol})$ could be observed during the first 3 minutes. During this period the major part of the total amount of FABP that was lost from the hearts during $\mathrm{Ca}^{2+}$ readmission was found in the effluents. After this period, however, the release of FA and FABP seemed to become 

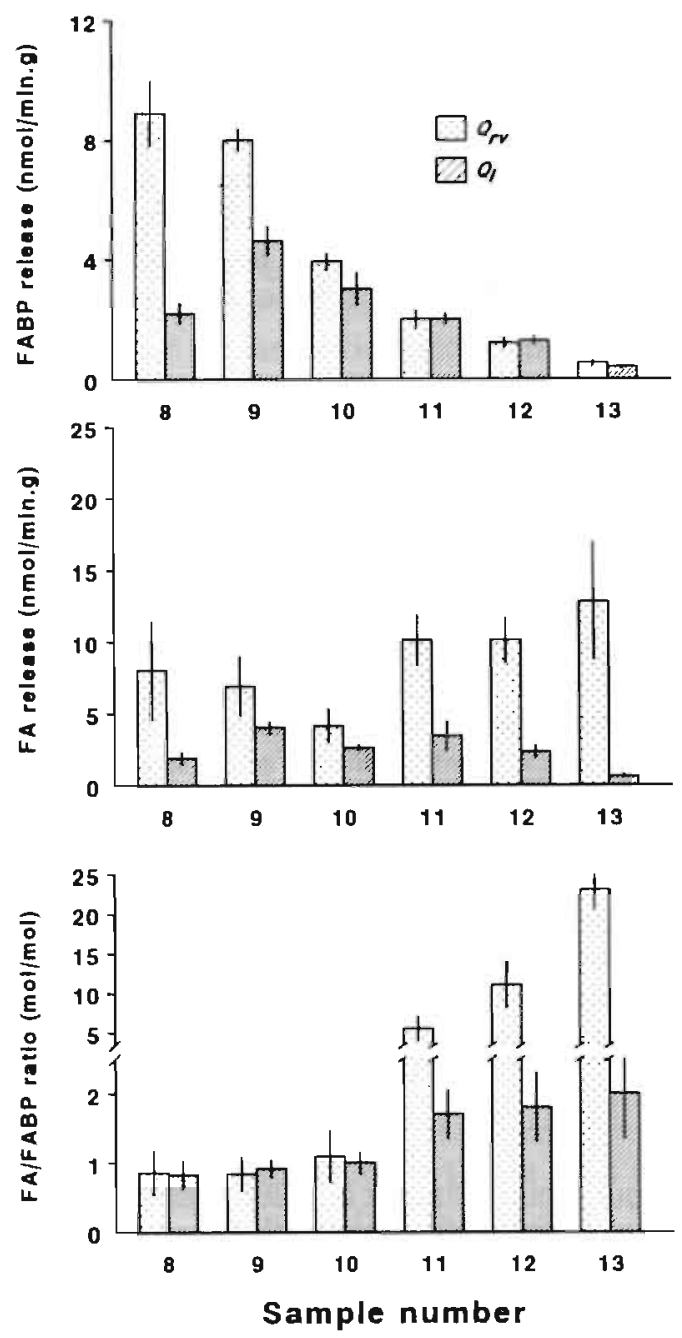

Fig. 8.4. Release of FABP (upper panel) and FA (middle panel) during $\mathrm{Ca}^{2+}$ readmission (Mean $\pm S E M, n=4$ or 5, see Table 8.1). The lower panel depicts the molar ratio of FAVFABP for each sample.

uncoupled in $Q_{r v}$ but not in $Q_{i}$. Taken together, it might be concluded that initially FA are released bound to FABP, whereas after almost complete protein depletion of tissue, FA are released in a non-protein bound manner and predominantly in $Q_{r v}$ Moreover, since the bulk of $F A$ was found in $Q_{r v}$ these findings might indicate that after 3 minutes of $\mathrm{Ca}^{2+}$ readmission FA are largely released from endothelial cells and excreted at the luminal side of this cell-type. Release most likely occurs in the form of FA micelles or incorporated in endothelial derived vesicles, and most likely not as single FA molecules, since the aqueous solubility of FA is very low (Brodersen et al, 1989; Vorum et al, 1992). 


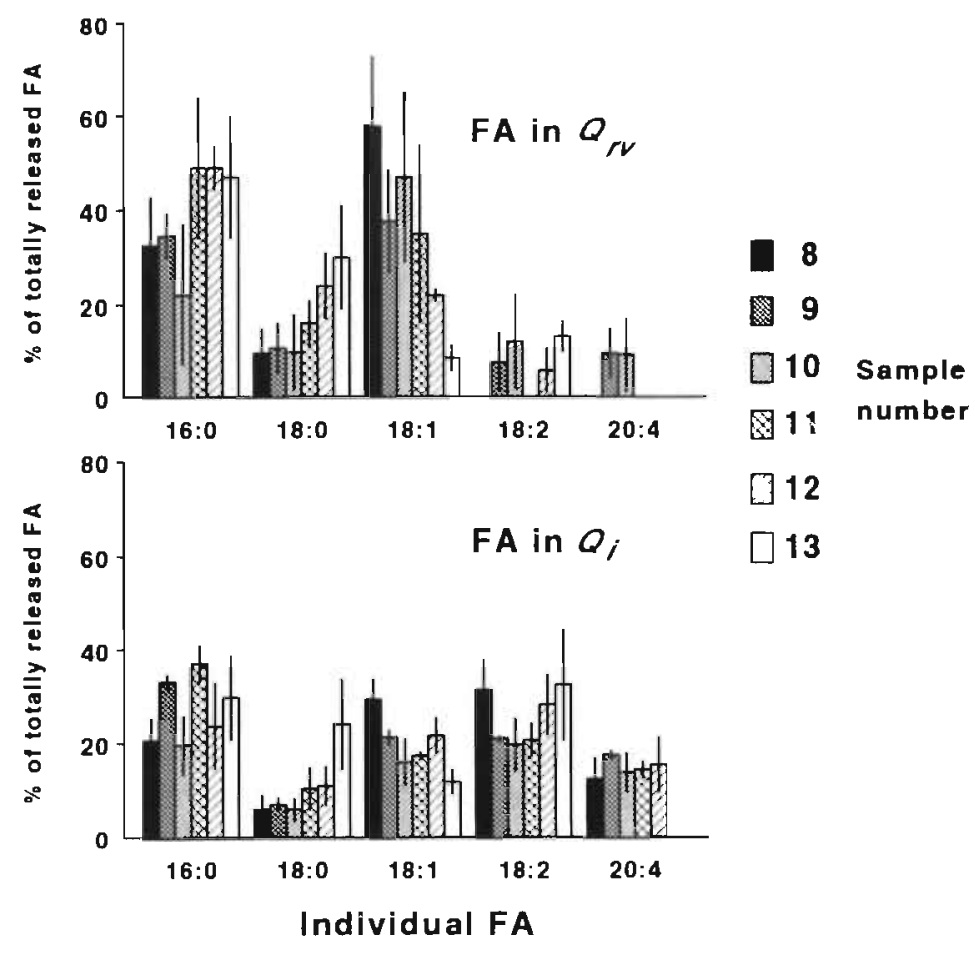

Fig. 8.5. Percentual distribution of individual FA in $Q_{r v}$ (upper panel) and $Q_{1}$ (lower panel) during $\mathrm{Ca}^{2}$. readmission (Mean \pm SEM, $n=4$ or 5 , see Table 8.1 ). See for explanation of sample numbers Figure 8.1. See Figure 8.3 for nomenclature of individual FA.

FA found in $Q_{i}$ is probably released from both the basolateral site of the endothelium and the cardiomyocytes. When the percentual FA composition in the samples is studied in more detail it can be observed that $Q_{n}$ and $Q$, fractions differ in composition (Figure 8.5). Especially in regard to $\mathrm{C} 18: 2$ and $\mathrm{C} 20: 4$ a marked difference is seen between the appearance of these $F A$ in $Q_{r v}$ and $Q_{i}$. This observation might also indicate that $F A$ in these fractions are released from different sites in the heart.

In a theoretical study (Chapter 6; Vork et al, 1992) we calculated that under normal conditions only a slight amount (1-2\%) of FABP is complexed with FA, whereas the bulk amount of FA is present in the sarcolemmal membrane. In the present study, however, a FA/FABP ratio of $0.9 \mathrm{~mol} / \mathrm{mol}$ was measured in the coronary effluent immediately at the onset of $\mathrm{Ca}^{2+}$ readmission, at which time the tissue FA concentration was still similar to preischemic values. Although not measured in the present study, it was observed by Van der Vusse et al (1988) that FA accumulation in tissue during $\mathrm{Ca}^{2+}$ readmission does not occur within the first $11 \frac{1}{2}$ minute, suggesting that $F A$ accumulation is a relatively late phenomenon. The apparent discrepancy between late tissue FA accumulation and early FA release might be explained by the following hypothesis. Immediately at the onset of $\mathrm{Ca}^{2+}$ readmission, hydrolysis of lipids (i.e. triacylglyceroles and phospholipids) does start in the affected tissue. However, since FABP is then still present in the tissue, FA are directly bound by FABP and subsequently released in combination with the protein, explaining the observation that tissue 
FA accumulation is not found during the first minutes, although FA release occurs. Assuming that FABP and FA are present in the same tissue compartment, the initial FA release might reflect the FA that are formed in the cardiomyocyte. Alternatively, it is possible that $F A$ and FABP are initially not present in the same compartment. In that situation FA accumulates in a compartment not accessible for FABP and association of FA and FABP subsequently has to occur in the interstitial and/or vascular space, i.e. after FABP has left the cardiomyocytes. On FABP depletion, however, a FA carrying substance is no longer present in the tissue and FA starts to accumulate, due to its limited solubility in the aqueous perfusion buffer. This explanation is in harmony with the observation of Van der Vusse and co-workers (1988) and with the FA and FABP release patterns shown in Figure 8.4, in which after an initial FA and FABP release in the first minute the release per minute decreases during the following 2 minutes for both compounds but then increases again, due to massive FA accumulation in tissue.

An alternative explanation for the observed high FAJFABP ratio of $0.9 \mathrm{~mol} / \mathrm{mol}$ is the following. During release of FABP from cardiac cells the protein has to cross the cellular membrane, possibly through pores, formed as a result of tissue injury (De Leiris and Hearse, 1984). It is not known by what mechanism intracellular constituents interact with the cellular membrane during crossing. It might be possible that during this crossing accumulated FA in the membrane are taken up from the membrane, thus increasing the FAVFABP ratio. If this phenomenon actually occurs, then it is difficult to interpret FA release patterns, since these patterns then most likely do not depict the endogenous FA binding by FABP, but merely illustrate that FABP can bind and take away FA from a membrane.

\section{CONCLUSION}

In conclusion it was found that FA is released from rat hearts subjected to ischemiareperfusion and subsequent $\mathrm{Ca}^{2+}$ paradox, initially co-released with FABP. From this observation it might be concluded that the putative FA buffering function of FABP does exists under severe pathological circumstances, at least during the onset of such condition. However, this scavenging did not have a beneficial effect, since more than $80 \%$ of the total FABP content was released from the tissue within 10 minutes, indicating almost complete tissue destruction. FA release from reperfused tissue after 60 minutes of ischemia could not be demonstrated in the present study. However, since the FABP release amounted only to $1-2 \%$ of total tissue content and the tissue FA concentration had not increased in our experimental model, it is most likely that FA release was too small to be detected with the assay used.

\section{ACKNOWLEDGEMENT}

The authors wish to thank Mr. T.H.M. Roemen for his advice concerning the assessment of fatty acids in cardiac effluents and Dr. M.L. Dubelaar for skilful help in the preparation of rat hearts. This work was supported by the Netherlands Heart Foundation, grant no. 88.073.

\section{REFERENCES}

Bass NM. 1988. The cellular fatty acid-binding proteins: Aspects of structure, regulation and function. Int Rev Cytol 111, 143-184.

Brecher P. 1983. The interaction of long-chain acyl CoA with membranes. Mol Cell Biochem 57, 3-15. 
Brodersen R, Skriver E. Pedersen AO. 1989. Serum albumin binding of palmitate and stearate: Muitiple binding theory of insoluble ligands. Eur J Biochem 182, 19-25.

Crohn C. Levitt DG. 1984. Capillary permeability to small solutes. In: Handbook of Physiology Sec 2, Vol IV, Chapter 10. American Physiological Society, Bethesda MD, USA.

De Deckere EAM, Ten Hoor P. 1977. A modified Langendorft technique for metabolic investigations. Plügers Arch 370, 103-105.

De Groot MJM, Willemsen PHM, Coumans WA, Van Bilsen M, Van der Vusse GJ. 1989. Lactate-induced stimulation of myocardial triacylglycerol turnover. Biochim Biophys Acta 1006, 111-115.

De Leiris J, Hearse DJ. 1984. Myocardial enzyme leakage as an indicator of cellular injury: principles and application. In: Methods in studying cardiac membranes. Ed. N. Dhalla. Chapter 17. CRC press, Boca Raton FL, USA.

Folch J, Lees M, Stanley GHS. 1957. A simple method for the isolation and purification of total lipids from animal tissue. J Biol Chem 226, 497-509.

Ganote CE, Sims MA, Van Der Heide RS. 1983. Mechanisms of enzyme release in the calcium paradox. Eur Heart J 4 (suppl. H), 63-71.

Glatz JFC, Paulussen RJA, Veerkamp JH. 1985. Fatty acid binding proteins from heart. Chem Phys Lipids 38, 115-129.

Glatz JFC, Van Bilsen M, Paulussen RJA, Veerkamp JH, Van der Vusse GJ, Reneman RS. 1988. Release of fatty acid-binding protein from isolated rat heart subjected to ischemia and reperfusion or to the calcium paradox. Biochim Biophys Acta 961, 148-152.

Glatz JFC, Van der Vusse. 1989. Intracellular transport of lipids. Mol Cell Biochem 88, 37-44.

Glatz JFC, Van der Vusse GJ. 1990. Celiular fatty acid-binding proteins: Current concepts and future directions. Mol Cell Biochem 98, 247-251.

Glatz JFC. Van der Vusse GJ, Reneman RS. 1991. Protective role of fatty acid-binding protein in ischemic and reperfused heart (letter). Circ Res 68, 1490.

Guyton AC. 1991. Textbook of medical physiology. 8th edition, Chapter 16, W.B. Saunders Co, Philadelphia, USA.

Hülsmann WC, Dubelaar ML. 1987. Early damage of vascular endothelium during cardiac ischaemia. Cardiovasc Res 21, 674-677.

Kaikaus RM, Bass NM, Ockner RK. 1990. Functions of fatty acid binding proteins. Experientia 46, 617-630. Katz AM, Messineo FC. 1982. Lipid-membrane interactions and the pathogenesis of ischemic damage in the myocardium. Circ Res 48, 1-16.

Katz AM. 1982. Membrane derived lipids and the pathogenesis of ischemic myocardial damage. J Mol Cell Cardiol 14, 627-632.

Langendort O. 1895. Untersuchungen am überlebenden Saügetierherzen. Pflügers Arch 61, 291-332.

Matarese V. Stone RL, Waggoner DW, Bernlohr DA. 1989. Intracellular fatty acid trafticking and the role of cytosolic lipid binding proteins. Prog Lipid Res 28, 245-272.

Neely JR, Grotyohann LW. 1984. Role of glycolytic products in damage to ischemic myocardium. Circ Res 55, 816-824.

Roemen THM, Van der Vusse GJ. 1991. Assessment of fatty acids in cardiac tissue as 9-anthryldiazomethane esters by high-performance liquid chromatography. J Chromatography 570, 243-251.

Srimani BN, Engelman RM, Jones R, Das DK. 1990. Protective role of intracoronary latty acid-binding protein in ischemic and reperfused myocardium. Circ Res 66, 1535-1543.

Van Bilsen M, Van der Vusse GJ, Willemsen PHM, Coumans WA, Roemen THM, Reneman RS. 1989. Lipid alterations in isolated, working heart during ischemia and reperfusion: Its relation to myocardial damage. Circ Res 64, 304-314.

Van Bilsen M, Van der Vusse GJ, Willemsen PHM, Coumans WA, Reneman RS. 1991. Fatty acid accumulation during ischemia and reperfusion: Effects of pyruvate and POCA, a carnitine palmitoyltransferase I inhibitor. J Mol Cell Cardiol 23, 1437-1447.

Van der Vusse GJ, Roemen THM. Prinzen FW, Coumans WA, Reneman RS. 1982. Uptake and tissue content of fatty acids in dog myocardium under normoxic and ischemic conditions. Circ Res 50, 538-546.

Van der Vusse GJ, Prinzen FW, Van Bilsen M, Engels W, Reneman RS. 1987. Accumulation of lipids and lipid-intermediates in the heart during ischemia. Basic Res Cardiol 82 (suppl. 1), 157-167.

Van der Vusse GJ, Van Bilsen M, Willemsen P. Reneman RS. 1988. The myocardial content of fatty acids and phospholipids during the calcium paradox. J Mol Cell Cardiol 20,617-623.

Van der Vusse GJ, Glatz JFC, Stam HCG, Reneman RS. 1992. Fatty acid homeostasis in the normoxic and ischemic heart. Physiol Rev 72, 881-940. 
Veerkamp JH, Peeters RA, Maatman RGHJ. 1991. Structural and functional features of different types of cytoplasmic fatty acid-binding proteins. Biochim Biophys Acta 1081, 1-24.

Vork MM, Glatz JFC, Surtel DAM, Van der Vusse GJ. 1990. Assay of the binding of fatty acids by proteins: evaluation of the Lipidex 1000 procedure. Mol Cell Biochem 98, 111-117.

Vork MM, Glatz JFC, Surtel DAM, Knubben HJM, Van der Vusse GJ. 1991. A sandwich enzyme linked immuno-sorbent assay for the determination of rat heart fatty acid-binding protein using the streptavidin-biotin system. Application to tissue and effluent samples from normoxic rat heart perfusion. Biochim Biophys Acta 1075, 199-205.

Vork MM, Glatz JFC, Van der Vusse GJ. 1993. On the mechanism of long chain fatty acid transport in cardiomyocytes as facilitated by cytoplasmic fatty acid-binding protein. J Theor Biol 160, 207-222.

Vorum H, Brodersen R, Kragh-Hansen U, Pedersen AO. 1992. Solubility of long-chain fatty acids in phosphate buffer at $\mathrm{pH}$ 7.4. Biochim Biophys Acta 1126, 135-142.

Waggoner DW, Bernlohr DA. 1990. In situ labeling of the adipocyte lipid binding protein with 3-[25I]lodo-4azido- $N$-hexadecylsalicylamide. J Biol Chem 265, 11417-11420.

Waggoner DW, Manning JA, Bass NM, Bernlohr DA. 1991. In situ binding of fatty acids to the liver fatty acid binding protein: Analysis using $3-\left[{ }^{125} \mid\right]$ lodo-4-azido- $N$-hexadecylsalicylamide. Biochem Biophys Res Commun $180,407-415$.

Zimmerman ANE, Hülsmann WC. 1966. Paradoxical influence of calcium ions on the permeability of the cell membrane of the isolated rat heart. Nature 211, 646-647. 


\section{CHAPTER 9}

\section{GENERAL DISCUSSION}


In the present thesis an attempt has been made to gain more insight into the physiological significance of a small intracellular fatty acid-binding protein (FABP) found in the heart. Although the presence of distinct types of FABP in many mammalian tissues is well documented, their true physiological function(s) are still incompletely understood. Long chain fatty acids are poorly soluble in an aqueous environment (Brodersen et al, 1990; Vorum et al, 1992), indicating that these substances need a solubilizing factor for efficient transport. A number of indirect observations suggest that FABP might play this important role in the intracellular translocation and processing of long chain fatty acids. The main reasons to assume this function are:

1. FABP will bind fatty acids in vitro (Mishkin et al, 1972; Ockner et al, 1972).

2. Data are available suggesting that fatty acids are bound to FABP in cultured cells (Waggoner and Bernlohr, 1990; Waggoner et al, 1991).

3. FABP stimulates the exchange of fatty acids between lipid membranes (McCormack and Brecher, 1987; Peeters and Veerkamp, 1989).

4. Organs showing an active lipid metabolism, such as heart, liver, intestinal epithelium and adipose tissue, each contain a relatively high amount of one or more specific types of FABP (Glatz et al, 1988a).

In the present studies additional information was obtained about a number of biochemical features of FABP and several indications for an important function of this protein in myocardial lipid homeostasis. These new contributions comprise (I) improvement of methods used in the study of FABP, (ii) additional information concerning the role of the protein under normal physiological conditions, including a mathematical model to calculate the effect of FABP on intracellular fatty acid transport and (iii) insights into the behaviour of FABP in patho-physiological situations.

\section{Methodological improvements}

At the onset of the studies described in this thesis a variety of data was available concerning fatty acid-binding characteristics of heart FABP and its tissue content. However, these values were rather heterogeneous, most likely caused by the use of inadequate laboratory techniques. Therefore, the initial aim was to improve and develop methods for the accurate assessment of these parameters.

To study the process of fatty acid binding by FABP, an existing method using Lipidex 1000 (Glatz and Veerkamp, 1983) was improved. Appreciable differences in published values were suspected to be caused by the inaccurate use of this method. Indeed it was found that substantial losses of both tatty acids and FABP occurred during the performance of the assay, when no special precautions were taken to avoid these phenomena. Addition of Triton X-100 to the incubation mixture limited fatty acid loss substantially and completely eliminated FABP loss. With this method, heart-type FABP showed a maximum fatty acid binding stoichiometry $\left(B_{\max }\right)$ of one to one, whereas the affinity constant $\left(K_{d}\right)$ was measured to amount to $0.2 \mu \mathrm{M}$ (Chapter 3; Vork et al, 1990).

For the quantification of FABP in biological samples a sensitive and disturbance free enzyme linked immunosorbent assay was developed. With this assay it was found that rat heart contains $0.7-0.9 \mathrm{mg}$ FABP per gram tissue, depending on the strain under investigation (Chapters 4 and 5; Vork et al, 1991; Vork et al, 1992a). These values are 
appreciably lower than earlier reported data (Bass and Manning, 1986; Crisman et al, 1987; Knowlton et al, 1989; Paulussen et al, 1989).

\section{Physiological significance of fatty acid-binding protein}

Applying the developed immunochemical assay, it was found that the FABP concentration in red skeletal muscles is up to about 20 -fold higher than that in white skeletal muscles (Chapter 4; Vork et al, 1991). Since red muscle fibres (type I fibres) predominantly use fatty acids for the generation of energy, whereas white fibres (type II fibres) mainly rely on glucose utilization, this observation suggests the existence of a relationship between the capacity of a skeletal muscle to utilize fatty acids and its FABP content, as previously reported to exist among a number of tissues (Glatz et al, 1988a). In the heart, the muscle fibres of which show a continuous activity, the measured FABP content per gram wet tissue was the highest of all muscles under investigation. This finding would suggest that the FABP level in skeletal muscle could still be increased on an enhancement of muscle activity. However, no such increase in FABP content was detected in rat soleus muscle upon physical endurance training, but a small but significant increase was found by testosterone administration to female rats (Van Breda et al, 1992).

In rat heart, transmural FABP concentration differences in the wall of the left ventricle were measured (Chapter 5; Vork et al, 1992a). The FABP concentration in the outer layer of the left ventricular wall was found to be slightly but significantly higher than that in the inner layer. At present it remains unclear whether transmural differences in energy metabolism exist in the heart (Van der Vusse et al, 1990). If these differences exists, they are probably in the order of $10-20 \%$. Van der Vusse and colleagues (1990) measured a significant difference of about $15 \%$ in the utilization of palmitate by the outer and inner layers of the left ventricular wall in the dog, being highest in the outer tissue region. Although the transmural differences in both the palmitate oxidation capacity and the FABP concentration are moderate, it also gives an indication about a close relationship between these two parameters.

In Chapter 6 (Vork et al, 1992b) a relatively simple mathematical model is presented which may give more insight into the transporting function of FABP. The calculations are based on various data reported by other research groups as well as obtained in our laboratory. The main conclusions from this model are that FABP enhances the intracellular cytoplasmic fatty acid concentration almost three orders of magnitude, which results in a fatty acid transport increase of more than one order of magnitude. Although these theoretical calculations contain several assumptions, their results strongly suggest that experimentally measured rates of fatty acid oxidation in the heart can not be explained in the hypothetical absence of FABP. This holds in particular for transport of fatty acids from the sarcolemma to the intermyofibrillar mitochondria in the heart.

\section{Fatty acid-binding protein at pathophysiological conditions}

Under pathological conditions, e.g. ischemia, the concentration of fatty acids in cardiac tissue will rise (Van der Vusse et al, 1992). FABP has been suggested (Brecher, 1983; Glatz et al, 1985) to be involved in the binding of these excess fatty acids, so as to avoid detrimental action of these compounds on cellular constituents (Katz and Messineo, 1982). Furthermore, it was found that FABP is released from cardiac tissue during reperfusion after a period of ischemia (Glatz et al, 1988b). Taken together, it might be expected that FABP and fatty acids are released simultaneously from ischemia injured cardiac tissue. 
Therefore, initially the release of FABP from ischemic cardiac tissue was studied in detail. The primary goal of this set of experiments was to delineate as to whether release from tissue is related to the molecular mass of the protein. When a comparison was made between FABP $(15,000 \mathrm{Da})$ and lactate dehydrogenase ( $\mathrm{LDH} ; 130,000 \mathrm{Da})$, no differences in the release patterns of these proteins could be detected (Chapter 7). However, LDH was released in a larger quantity than FABP, when compared to the tissue content of these proteins. This finding suggests that the release of proteins from injured tissue depends on a variety of physico-chemical properties of the proteins and of the intracellular environment. It was shown recently by our group (Kleine et al, 1992) that in cardiac patients the release of FABP was complete in a shorter period than that of $\mathrm{LDH}$. Together with the findings for isolated rat hearts it may be concluded that the appearance of intracellular proteins in plasma in situ depends not only on the mechanism by which proteins leave the injured cell but also on the behaviour and transport of these proteins in the interstitial and lymphatic systems towards the bloodstream.

In a following set of experiments the release of FABP in combination with fatty acids was studied from isolated rat hearts (Chapter 8; Vork et al, 1993). Upon induction of relatively large tissue damage ( $>80 \%$ of total tissue FABP released within ten minutes), by means of the calcium paradox, FABP and fatty acids were indeed released simultaneously from the tissue, initially in a one to one molar ratio. Although it is unknown at what location in the tissue these excess fatty acids were bound, the results suggest that FABP does bind fatty acids at the interior of the cell.

\section{Future directions}

The primary reason for the absence of physiological evidence for the putative transporting function of FABP is most likely the lack of techniques enabling researchers to actually visualize FABP mediated fatty acid transport in vivo. It is difficult to imagine how such technique could be used in whole organs. Therefore, a suitable candidate model to study is the isolated cell. Such system should have a number of properties: (I) traceable, e.g. fluorescently labeled, fatty acids should be readily taken up by the isolated cell; (ii) such modified fatty acids should be bound by FABP with similar affinity as would native fatty acids; (iii) FABP bound fatty acids must be discriminated from non-bound or membrane bound fatty acids.

A variety of modified fatty acids have been used in the past to study fatty acid binding by FABP, such as 1-pyrene-nonanoic acid (Keuper et al, 1985), anthroyloxy labeled fatty acids (Keuper et al, 1985; Reers et al, 1984; Rüdel et al, 1985; Storch and Bass, 1990) and dansyl-undecanoic acid (Wilkinson and Wilton, 1986). In a few studies it has been reported that fatty acids, labeled with a readily detectable chemical group, are quickly taken up by the cell (Waggoner and Bernlohr, 1990; Storch et al, 1991). These observations indicate that the cellular uptake of modified fatty acids is probably not a major practical problem. Peeters and colleagues (1989) measured the apparent affinity of FABPs for several modified fatty acids. They found that binding of labeled fatty acids depends on the type of FABP and fatty acid studied. In general these investigators found that liver FABP showed somewhat higher affinities for labeled fatty acids as compared with oleic acid whereas the affinity of heart FABP for these fatty acids was lower, especially for dansyl-undecanoic acid. From these findings it can be concluded that the choice of a labeled fatty acid depends on the cell-type and FABP type under investigation. The use of anthroyloxy fatty acids is less suitable in the model described above because the fluorescence intensity of these substances hardly changes on binding to lipid bilayers or FABP (Storch et al, 1989). To date the most suitable 
fatty acid for the study of intracellular fatty acid transfer appears to be dansyl-undecanoic acid, since its fluorescence intensity increases manyfold on binding to liver FABP, with an accompanied shift in the fluorescence emission maximum (Wilkinson and Wilton, 1986). However, as already indicated, this fatty acid analogue is only moderately bound by heart FABP, and is therefore less suitable when cardiomyocytes are studied. Another, yet not developed, fatty acid derivate with the same fluorescent properties as dansyl undecanoic acid and with similar binding kinetics to all types of FABP would be the most appropriate substance for the study of cardiac intracellular fatty acid movement.

An alternative approach for the study of intracellular fatty acid transport is the use of nuclear magnetic resonance (NMR). Cistola and co-workers (1990) have used this technique to study the interaction of FABP with fatty acids in vitro. This technique has several advantages, the most important being the use of native ${ }^{13} \mathrm{C}$ enriched fatty acids instead of fluorescent fatty acid derivates. NMR has been used to monitor alterations in, for instance, adenine nucleotide homeostasis in the heart in situ (Schaefer et al, 1990). However, to date NMR is not very sensitive and therefore requires large amounts of the substance under investigation, which makes it less suitable for the study of cellular systems. However, it might become an important tool for the study of FABP in cultured cell systems in the near future.

The first report on the use of molecular biological techniques in the field of FABP research was presented by Lowe and colleagues (1984), who were able to express large amounts of liver FABP in E. Coli. To date, several FABP types have been expressed in $E$. Coli (reviewed by Veerkamp et al, 1991), mainly to obtain large amounts of FABP needed for NMR and X-ray crystallographic studies (Cistola et al, 1990; Sacchettini et al, 1990). Only a single study describes the transfection of a mammalian cell type with cloned cDNA encoding rat liver FABP (Jefferson et al, 1990). It can be expected that molecular biological methods will be more widely employed in FABP research in the near future, since using these methods may give better insight into the physiological function of FABPs. It might enable researchers $(1)$ to modulate the tissue FABP content efficiently, thereby overexpressing or alternatively suppressing or completely knocking-out the expression of the FABP gene(s), (ii) to express FABP in cell types containing little or no FABP, such as cardiac endothelial cells, (iii) to induce specific mutations in the FABP genome in order to alter the fatty acid-binding characteristics of FABP. (iv) to create transgenic animals (Cohn et al, 1992) with, for instance, no expression of FABP in tissues normally expressing appreciable amounts of the protein, in order to study changes in the lipid metabolism of those tissues.

\section{REFERENCES}

Bass NM, Manning JA. 1986. Tissue expression of three structurally different fatty acid-binding proteins from rat muscle, liver and intestine. Biochem Biophys Res Commun 137, 929-935.

Brodersen R, Vorum H, Skriver E, Pedersen AO. 1989. Serum albumin binding of palmitate and stearate. Multiple binding theory for insoluble ligands. Eur $\mathrm{J}$ Biochem 182, 19-25.

Brecher P. 1982. The interaction of long-chain acyl CoA with membranes. Mol Cell Biochem 57, 282-291. Cistola DP, Sacchettini JC, Gordon JI. $1990 .{ }^{13} \mathrm{C}$ NMR studies of fatty acid-protein interactions: comparison of homologous fatty acid-binding proteins produced in the intestinal epithelium. Mol Cell Biochem 98, 101-110. Cohn SM, Simon TC, Roth KA, Birkenmeier EH, Gordon JI. 1992. Use of transgenic mice to map cis-acting elements in the intestinal fatty acid-binding protein gene (Fabpl) that control its cell lineage-specific and regional patterns of expression along the duodenal-colonic and crypt-villus axes of the gut epithelium. J Cell Biol 119, 27-44. 
Crisman TS, Claffey KP, Saouaf R, Hanspal J, Brecher P. 1987. Measurement of rat heart fatty acid-binding protein by ELISA. Tissue distribution, developmental changes and subcellular distribution. J Mol Cell Cardiol $19,423-431$.

Glatz JFC, Veerkamp JH. 1983. A radiochemical procedure for the assay of fatty acid-binding by proteins. Anal Biochem 132, 89-95.

Glatz JFC, Paulussen RJA, Veerkamp JH. 1985. Fatty acid binding proteins from heart. Chem Phys Lipids 38, 115-129.

Glatz JFC, Van der Vusse GJ, Veerkamp JH. 1988a. Fatty acid-binding proteins and their physiological significance. News Physiol Sci 3, 41-43.

Glatz JFC, Van Bilsen M, Paulussen RJA, Veerkamp JH, Van der Vusse GJ, Reneman RS. 1988b. Release of fatty acid-binding protein from isolated rat heart subjected to ischemia and reperfusion or to the calcium paradox. Biochim Biophys Acta 961, 148-152.

Jefferson JR, Powell DM, Rymaszewski Z, Kukowska-Latallo J, Lowe JB, Schroeder F. 1990. Altered membrane structure in transfected mouse L-cell fibroblasts expressing rat liver fatty acid-binding protein. J Biol Chem 265, 11062-11068.

Katz AM, Messineo FC. 1982. Lipid-membrane interactions and the pathogenesis of ischemic damage in the myocardium. Circ Res 48, 1-16.

Keuper HJ, Klein RA, Spener F. 1985. Spectroscopic investigations on the binding site of bovine hepatic fatty acid-binding protein. Evidence for the existence of a single binding site for two fatty acid molecules. Chem Phys Lipids 38, 159-173.

Kleine AH, Glatz JFC, Van Nieuwenhoven FA, Van der Vusse GJ.

1992. Release of heart fatty acid-binding protein into plasma after acute myocardial infarction in man. Mol Cell Biochem 116, 155-162.

Knowlton AA, Apstein CS, Saouaf R, Brecher P. 1989. Leakage of heart fatty acid-binding protein with ischemia and reperfusion in the rat. $\mathrm{J}$ Mol Cell Cardiol 21, 577-583.

McCormack M, Brecher P. 1987. Effect of liver fatty acid-binding protein on fatty acid movement between liposomes and rat liver microsomes. Biochem $\mathrm{J} 244,717-723$.

Lowe JB, Strauss AW, Gordon Jl. 1984. Expression of mammalian fatty acid-binding protein in Escherichia Coli. J Biol Chem 259, 12696-12704.

Mishkin S, Stein L, Gatmaitan Z, Arias IM. 1972. The binding of fatty acids to cytoplasmic proteins: binding to $Z$ protein in liver and other tissues of the rat. Biochem Biophys Res Commun 47, 997-1003.

Ockner RK, Manning JA, Poppenhausen RB, Ho WKL. 1972. A binding protein for fatty acids in cytosol of intestinal mucosa, liver, myocardium and other tissues. Science 177, 56-58.

Paulussen RJA, Geelen MJH, Beynen AC, Veerkamp JH. 1989. Immunochemical quantitation of fatty acidbinding protein. I. Tissue and intracellular distribution, postnatal development and influence of physiological conditions on rat heart and liver fatty acid-binding protein. Biochim Biophys Acta 1001, 201-209.

Peeters RA, In 't Groen M, De Moel MP, Van Moerkerk HTB, Veerkamp JH. 1989. The binding affinity of fatty acid-binding proteins from human, pig and rat liver for different fluorescent fatty acids and other ligands. Int $J$ Biochem 21, 407-418.

Peeters RA, Veerkamp JH. 1989. Does fatty acid-binding protein play a role in fatty acid transport? Mol Cell Biochem 88, 45-49.

Reers M, Elbracht R, Rüdel H, Spener F. 1984. Rapid methods for the characterization of unilammelar phospholipid vesicles. Application to studies on fatty acid donor and acceptor properties of membranes and fatty acid-binding proteins. Chem Phys Lipids 36, 15-28.

Rüdel H, Underberg C, Spener F. 1985. Wechselwirkungen kardialer Fettsaürebindungsproteine mit Fettsaüren und intrazellulären membranen. Fette Seifen AnstrMittel 87, 561-567.

Sacchettini JC, Banaszak LJ, Gordon JI. 1990. Expression of rat intestinal fatty acid-binding protein in E. Coli and its subsequent structural analysis: a model for studying the molecular details of fatty acid-protein interaction. Mol Cell Biochem 98, 81-93.

Schaefer S, Gober JR, Schwartz GG, Twieg DB, Weiner MW, Massie B. 1990. In vivo phosphorus-31 spectroscopic imaging in patients with global myocardial disease. Am J Cardiol 65, 1154-1161.

Storch J, Bass NM, Kleinfeld AM. 1989. Studies on the fatty acid-binding site of rat liver fatty acid-binding protein using fluorescent fatty acids. J Biol Chem 264, 8708-8713.

Storch J, Bass NM. 1990. Transfer of fluorescent fatty acids from liver and heart fatty acid-binding proteins to model membranes. J Biol Chem 265, 7827-7831.

Storch J, Lechene C. Bass NM. 1991. Direct determination of free fatty acid transport across the adipocyte plasma membrane using quantitative fluorescence microscopy. J Biol Chem 266, 13473-13476. 
Van Breda E, Keizer HA, Vork MM, Surtel DAM, de Jong YF, Van der Vusse GJ, Glatz JFC. 1992. Modulation of fatty acid-binding protein content of rat heart and skeletal muscle by endurance training and testosterone treatment. Pflügers Arch 421, 274-279.

Van der Vusse GJ, Arts T, Glatz JFC, Reneman RS. 1990. Transmural differences in energy metabolism of the left ventricular myocardium: Fact or fiction? J Mol Cell Cardiol 22, 23-37.

Van der Vusse GJ, Glatz JFC, Stam HCG, Reneman RS. 1992. Fatty acid homeostasis in the normoxic and ischemic heart. Physiol Rev 72, 881-940.

Vork MM, Glatz JFC, Surtel DAM, Van der Vusse. 1990. Assay of the binding of fatty acids by proteins: evaluation of the Lipidex 1000 procedure. Mol Cell Biochem 98, 111-117.

Vork MM, Glatz JFC, Surtel DAM, Knubben HJM, Van der Vusse GJ. 1991. A sandwich enzyme linked immuno-sorbent assay for the determination of rat heart fatty acid-binding protein using the streptavidin-biotin system. Application to tissue and effluent samples from normoxic rat heart perfusion. Biochim Biophys Acta 1075, 199-205.

Vork MM, Trigault N, Snoeckx LHEH, Glatz JFC, Van der Vusse GJ. 1992a. Heterogeneous distribution of fatty acid-binding protein in the hearts of wistar kyoto and spontaneously hypertensive rats. $\mathrm{J}$ Mol Cell Cardiol 24, 317-321.

Vork MM, Glatz JFC, Van der Vusse GJ. 1993. On the mechanism of long chain fatty acid transport in cardiomyocytes as facilitated by cytoplasmic fatty acid-binding protein. J Theor Biol 160, 207-222.

Vork MM, Glatz JFC, Van der Vusse GJ. 1993. Release of fatty acid-binding protein and long chain fatty acids from isolated rat heart after ischemia and subsequent calcium paradox. Mol Cell Biochem, in press.

Vorum H, Brodersen R, Kragh-Hansen U, Pedersen AO. 1992. Solubility of long-chain fatty acids in phosphate buffer at $\mathrm{pH}$ 7.4. Biochim Biophys Acta 1126, 135-142.

Veerkamp JH, Peeters RA, Maatman RGHJ. 1991. Structural and functional features of different types of cytoplasmic fatty acid-binding proteins. Biochim Biophys Acta 1081, 1-24.

Waggoner DW, Bernlohr DA. 1990. In situ labeling of the adipocyte lipid binding protein with $\left.3-\left[{ }^{125}\right]\right]$ lodo-4. azido- $N$-hexadecylsalicylamide. J Biol Chem 265, 11417-11420.

Waggoner DW, Manning JA, Bass NM, Bernlohr DA. 1991. In situ binding of fatty acids to the liver fatty acid binding protein: Analysis using 3-[25] lodo-4-azido- $\mathrm{N}$-hexadecyl-salicylamide. Biochem Biophys Res Commun 180, 407-415.

Wilkinson R, Wilton D. 1986. Studies on fatty acid-binding proteins. The detection and quantification of the protein from rat liver by using a fluorescent fatty acid analogue. Biochem $J \mathbf{2 3 8}, 419424$. 


\section{SUMMARY}

The heart pumps blood through the entire body in order to supply all tissues with oxygen and other nutritional substances (substrates). During resting conditions the total bloodvolume (5-6 litres) is pumped once every minute; this is called the cardiac output and is the product of the number of beats per minute (heart rate) and the blood volume which is pumped through the vasculature per beat (stroke volume). During heavy exercise the cardiac output can amount up to $40 \mathrm{l} / \mathrm{min}$ as a result of an increase in both the heat rate and the stroke volume. Thus the heart is an extraordinary powerful and active organ. To perform this action the heart itself needs an appreciable amount of substrates. Therefore, already during rest about $4 \%$ of the total blood is pumped directly through the vasculature of the heart (coronary circulation). The heart has a preference for fatty acids as fuel during normal conditions, although other substrates can be used readily as well, such as glucose and lactic acid. During a single passage of the blood through the coronary circulation up to $70 \%$ of the supplied fatty acids can be taken up by the cardiac tissue. Fatty acids contain a large amount of potential chemical energy, which is liberated during combustion and subsequently used for pump activity.

Since fatty acids are poorly soluble in an aqueous environment they are transported in blood coupled to a protein, i.e. albumin. Albumin increases the solubility of fatty acids 10,000 to 20,000 fold. Following uptake in the heart muscle cells (cardiomyocytes), fatty acids are transported to the mitochondria, the power plants of the cell. In these cell organelles fatty acids are broken down in an oxidative process, during which the stored energy is liberated.

About two decades ago a small protein was detected in cardiac tissue which was capable to bind fatty acids under laboratory conditions (in vitro). This so-called fatty acidbinding protein was soon considered the intracellular counterpart of albumin. However, to date this putative transport function as well as other functions have not been established.

After a brief introduction (chapter 1) an overview of the distinct lipid transporting systems in the body is given in chapter 2 of the present thesis, with emphasis on the intracellular fatty acid protein FABP.

The purpose of the present thesis was to gain insight into the (patho)-physiological significance of FABP. At the onset of the project it turned out that several researchers had published important characteristics of the protein. However, these parameters were fairly diverse. Therefore, the initial aim of the investigation was to develop methods to accurately assess several biochemical parameters. In chapter 3 a method for the determination of fatty acid-binding properties of FABP (or any other protein) is described. Important parameters are the affinity constant $K_{d}$, which gives an impression about the 'eagerness' by which FABP binds and releases fatty acids, and the binding parameter $B_{\max }$, which indicates how many fatty acid molecules can be bound by a single FABP molecule.

To accurately quantify the amount of FABP in rat heart tissue and other samples, a sensitive immunological technique was developed (chapter 4). Besides in heart muscle, FABP was quantified in several skeletal muscles as well. It was found that the amount of FABP was appreciably higher in red muscles (which are largely depending on fatty acid oxidation) than in white muscles (which hardly use fatty acids). This was an indication that there might exist a relation between these parameters. Further evidence of this relation is presented in chapter 5 . In that chapter a heterogeneous distribution of FABP in the wall of the left ventricle, that part of the heart which pumps blood straight into the systemic 
circulation, is described. It was found that the outer tissue layer contained a somewhat higher amount of FABP than the inner layer. Earlier experiments had already shown that the capacity to metabolize fatty acids differs comparably in these tissue layers.

In order to gain an impression about the fatty acid transporting capacity of FABP in the cardiac muscle cell a mathematical model was set up (chapter 6). Calculations were performed with findings from our own investigations but also from other researchers. From these calculations it appeared that FABP can increase the transport of fatty acids in the cardiomyocyt 10 to 20 fold as compared with the hypothetical situation in which no FABP is present. Moreover, observed rates of cardiac fatty acid uptake can be explained only when an appreciable concentration of FABP is present in this cell-type. These results, therefore, suggest that FABP is necessary to ensure a sufficient supply of fatty acids to the mitochondria, and especially those lying in the innermost regions of the cardiomyocytes.

The release of intracellular proteins from injured tissue (e.g. enzymes) during and after an ischemic insult (i.e. a period in which no substrates are supplied to the heart) has become a powerful tool in the diagnosis of a myocardial infarction. One of the causes for the loss of proteins from damaged cells might be the formation of small pores in the cellular membrane, through which the proteins can leave the cell. If the size of these putative pores is related to the extent of the insult, it might be possible that small proteins are lost from the tissue earlier than larger molecules. To gain insight in this process, a series of experiments was performed making use of the model according to Langendorff. In this model the coronary vasculature of an isolated rat heart is perfused via the aorta with a medium containing all substrates necessary to maintain cardiac contraction. During a prolonged period of time ( 3 hours) the perfusion was severely depressed ( $15 \%$ of normal flow, i.e. lowflow ischemia). During this period the leakage of FABP from the tissue was compared with that of lactate dehydrogenase (LDH), an enzyme with an approximate 10 fold higher molecular mass. Despite the difference in molecular mass, the release patterns were similar for both proteins. Upon reperfusion (restoration of normal perfusion) an appreciable part of both FABP and LDH were found to be released in the perfusion medium, most likely caused by a combination of ischemic tissue damage and reperfusion damage. However, in this period no differences in release patterns could be monitored as well. When the amounts of released protein was related to the total tissue content of the two proteins, it was found that LDH was even more released than FABP, indicating that the process of protein release from injured cardiac tissue is a complex one which depends on a variety of factors.

Upon ischemia of cardiac tissue, breakdown of phospholipids occurs (substances which make up an important part of the cellular membrane structures) resulting in an increase of the tissue fatty acid concentration. A high tissue fatty acid concentration is regarded to have several harmful effects on cardiac function. Some years ago it was postulated that FABP might play a role in the scavenging of these excess amounts of fatty acids, thereby diminishing the harmful effects of them. To test this hypothesis the isolated perfused heart model as described in chapter 7 was used (chapter 8). Perfusion of the tissue was stopped completely for 60 minutes (global ischemia), followed by a period of 30 minutes reperfusion. Earlier studies in our laboratory showed that this treatment results in an increase of tissue fatty acid concentrations. The hearts were subsequently subjected to the so-called calcium paradox, a procedure in which soluble intracellular constituents of the tissue are released quickly. It was found that FABP and fatty acids were released from the tissue in a 1:1 ratio, although no increase in tissue fatty acid concentrations had occurred during the preceding period. During the calcium paradox, however, tissue fatty acid concentrations increased 
dramatically. A possible explanation for these observations might be that fatty acids, which are liberated from phospholipids during the calcium paradox, are bound to FABP quickly and simultaneously released.

In summary the following conclusions can be drawn from the investigations presented in this thesis:

1. FABP plays an important role in the intracellular binding and transport of fatty acids.

2. The release of proteins from injured cardiac tissue is a complex process in which a variety of physico-chemical properties of the protein under study are most likely involved.

3. The putative buffering function of FABP at enhanced concentrations of fatty acids needs additional investigation. 


\section{SAMENVATTING}

Het hart pompt bloed door het gehele lichaam met als doel daarmee alle weefsels te voorzien van zuurstof en andere voedingsstoffen. In rust wordt het gehele bloedvolume (5-6 liter) één maal per minuut rondgepompt; dit wordt het hartminuutvolume genoemd en is een produkt van het aantal hartslagen per minuut (harttrequentie) en de hoeveelheid bloed die per hartslag het bloedvatenstelsel in wordt gepompt (slagvolume). Tijdens zware lichamelijke inspanning kan, als gevolg van een verhoging van zowel de hartfrequentie als het slagvolume, het hartminuutvolume oplopen tot $40 \mathrm{liter} / \mathrm{minuut}$. Het hart is dus een buitengewoon krachtig en actief orgaan. Om deze taak naar behoren te vervullen heeft het hart zelf een aanzienlijke hoeveelheid voedingsstoffen nodig. Daartoe wordt al tijdens rust ongeveer $4 \%$ van de totale hoeveelheid bloed direct door de bloedvaten van het hart (coronaire circulatie) gepompt. Onder normale omstandigheden heeft het hart een voorkeur voor vetzuren als brandstof, hoewel ook glucose en melkzuur kunnen worden gebruikt. Tijdens één enkele passage van het bloed door de coronaire circulatie kan tot $70 \%$ van de aangeleverde hoeveelheid vetzuren door het hartweefsel worden opgenomen. Vetzuren bevatten een grote hoeveelheid chemische energie die tijdens verbranding vrijkomt en gebruikt kan worden voor de pompaktiviteit. Vanwege de gebrekkige oplosbaarheid in een waterig milieu worden vetzuren in het bloed vervoerd aan een eiwit, te weten albumine. Albumine bewerkstelligt een toename van de vetzuur oplosbaarheid van 10.000 tot 20.000 maal. Na opname in de hartspiercellen (cardiomyocyten) worden vetzuren getransporteerd van de celmembraan naar de mitochondriën, de energiecentrales van deze cellen. In dit deel van de cel worden de vetzuren afgebroken in een oxidatief proces, waarbij de in het vetzuur opgeslagen energie beschikbaar komt.

Ongeveer 20 jaar geleden werd in hartweefsel een klein eiwit aangetoond dat in staat bleek om onder laboratoriumomstandigheden vetzuren te binden (in vitro). Dit vetzuurbindende eiwit (fatty acid-binding protein; FABP) werd al snel beschouwd als de intracellulaire tegenhanger van albumine. Echter, tot op heden is deze transportfunktie, evenals andere mogelijke functies van dit eiwit, niet onomstotelijk bewezen.

$\mathrm{Na}$ een korte inleiding (hoofdstuk 1) wordt in hoofdstuk 2 van dit proefschrift een overzicht van de verschillende vet-transporterende systemen in het lichaam gepresenteerd, waarbij de nadruk ligt op het intracellulaire vetzuurbindende eiwit FABP.

Het in dit proefschrift beschreven onderzoek had tot doel om meer inzicht te krijgen in de (patho)-fysiologische betekenis van FABP. Bij aanvang van het onderzoek bleek dat verschillende onderzoeksgroepen uiteenlopende gegevens hebben gepubliceerd over belangrijke karakteristieken van FABP. Daarom werden eerst twee methoden ontwikkeld voor het nauwkeurig en reproduceerbaar bepalen van enkele van deze eigenschappen. In hoofdstuk 3 wordt een methode beschreven waarmee de vetzuurbindende eigenschappen van FABP (of een willekeurig ander eiwit) kunnen worden bepaald. Belangrijke factoren hierbij zijn de affiniteitskonstante $\mathrm{K}_{d}$, die een indruk geeft over de 'gretigheid' waarmee FABP vetzuren bindt en weer afstaat aan de oplossing waarin het zich bevindt, en de bindingsfaktor $B_{\max }$, die aangeeft hoeveel vetzuren door één molecuul FABP kunnen worden gebonden.

Om de hoeveelheid FABP in rattehart weefsel en andere monsters nauwkeurig te bepalen werd een gevoelige techniek ontwikkeld waarmee met behulp van antilichamen het eiwit kon worden gekwantificeerd (Hoofdstuk 4). Buiten het FABP gehalte in de hartspier werd tevens de hoeveelheid FABP in diverse skeletspieren bepaald. Hierbij werd gevonden dat de hoeveelheid FABP aanzienlijk hoger was in rode spieren (die voor hun energievoorziening voornamelijk zijn aangewezen op de verbranding van vetzuren) dan in 
witte spieren (die nauwelijks vetzuren verbranden). Dit is een aanwijzing dat deze twee parameters mogelijk verbonden zijn met elkaar. Een versterking van deze mogelijke relatie bleek uit de resultaten beschreven in hoofdstuk 5 . In dit hoofdstuk staat beschreven dat in de wand van de linkerventrikel, de hartkamer die het bloed rechtstreeks de circulatie inpompt, het FABP gehalte in de buitenste weefsellaag hoger is dan in de binnenste weefsellaag. Eerder onderzoek had reeds aangetoond dat de capaciteit voor vetzuurverbranding van deze lagen op een zelfde verschil vertoont.

Om een indruk te krijgen van de vetzuurtransporterende capaciteit van FABP in de hartspiercel werd een mathematisch model opgesteld (Hoofdstuk 6). Voor deze berekeningen werden niet alleen gegevens uit eigen onderzoek gebruikt maar ook gegevens van andere onderzoekers. Uit de berekeningen bleek dat het in de hartspiercel aanwezige FABP het intracellulaire vetzuurtransport met een factor 10 tot 20 kan doen toenemen, vergeleken met de (hypothetische) situatie waarbij geen FABP in deze cellen aanwezig zou zijn. Bovendien werd gevonden dat de gemeten vetzuuropname door de hartspier niet verklaard kan worden zonder de aanwezigheid van FABP. Deze resultaten suggereren dat FABP noodzakelijk is om een voldoende aanvoer van vetzuren naar de mitochondrien, vooral die in de meer naar binnen gelegen delen van de hartcel, te garanderen.

Het vrijkomen van intracellulaire eiwitten (b.v. enzymen) tijdens en na weefsel beschadiging is een belangrijk hulpmiddel bij de diagnose van een hartinfarct. Een van de hypothesen voor het verlies van eiwitten uit beschadigde cellen is dat er poriën ontstaan in de celmembraan, waardoor eiwitten naar buiten kunnen lekken. Indien de grootte van deze poriën gerelateerd is aan de ernst van de beschadiging zou het te verwachten zijn dat laagmoleculaire eiwitten eerder uit de cel lekken dan grotere eiwitten. Om hier inzicht in te krijgen werd een reeks experimenten uitgevoerd waarbij gebruik gemaakt werd van het geïsoleerde geperfundeerde rattehart model volgens Langendorff (Hoofdstuk 7). In dit model wordt het coronaire vaatstelsel via de levensslagader (aorta) buiten het lichaam doorspoeld met een geschikte oplossing waarin zuurstof en andere voedingsstoffen aanwezig zijn, zodat het hart kan blijven contraheren. Gedurende langere tijd ( 3 uur) werd de coronaire doorstroming sterk verminderd (15\% van de normale doorstroming; zgn. low-flow ischemie). Hierbij werd het weglekken van FABP uit het weefsel vergeleken met het verlies van het enzym lactaat dehydrogenase (LDH), een eiwit met een molecuulgrootte van ongeveer 10 maal dat van FABP. Tijdens deze periode konden geen verschillen gedetecteerd worden in de uitstortpatronen van beide eiwitten. Toen vervolgens de normale doorstroming hersteld werd (reperfusie), bleek een aanzienlijk gedeelte van de weefselinhoud van zowel FABP als LDH uitgestort te worden, hetgeen waarschijnlijk veroorzaakt wordt door een combinatie van weefselschade ontstaan tijdens de ischemische periode en schade als gevolg van de reperfusie. Echter, ook gedurende deze laatste periode konden geen verschillen worden aangetoond in de uitstortpatronen van beide eiwitten. Dit betekent dat de molecuulgrootte van de eiwitten waarschijnlijk geen rol speelt in het proces van eiwitverlies uit de cellen. Gerelateerd aan de totale weefselinhoud van beide eiwitten werd er echter wel meer LDH dan FABP uitgestort, hetgeen een indicatie is dat er meer factoren dan molecuulgrootte een rol spelen bij het vrijkomen van eiwitten uit beschadigd hartspierweefsel.

Wanneer hartweefsel geen zuurstof en andere voedingsstoffen toegedient krijgt (ischemie), zal na verloop van tijd afbraak van onder andere fosfolipiden (stoffen die een belangrijk deel uitmaken van cellulaire membranen) plaatsvinden waardoor de vetzuurconcentratie in het hartweefsel stijgt. Hoge vetzuurconcentraties in het weefsel hebben over het algemeen een negatief effect op de hartfunktie. Enige jaren geleden werd gepostuleerd dat FABP mogelijke een rol zou kunnen spelen bij het binden (bufferen) van deze vetzuren, zodanig dat het schadelijke effect van deze vetzuren verminderd of teniet 
gedaan wordt. Om deze hypothese te testen werd wederom gebruik gemaakt van het geïsoleerde, geperfundeerde rattehart model (Hoofdstuk 8). De doorstroming van het hart werd gedurende 60 minuten volledig stopgezet (globale ischemie), gevolgd door een periode van 30 minuten doorstroming. Dit werd gedaan om het vetzuurgehalte van het hartweefsel te verhogen. Hierna werd het hart zodanig behandeld dat alle oplosbare bestanddelen zeer snel uit het weefsel zouden stromen (met behulp van de zogenaamde calcium paradox). Het bleek dat vetzuren en FABP hierbij in een 1:1 verhouding uit het weefsel vrijkwamen, ondanks het feit dat tijdens de voorafgaande periode in het weefsel geen noemenswaardige vetzuurstijging had plaatsgevonden. Het vetzuurgehalte van het weefsel bleek echter wel sterk te stijgen tijdens de calcium paradox. Een van de mogelijke verklaringen van deze waarnemingen is dat vetzuren die gevormd worden tijdens de calcium paradox, zeer snel aan het in het weefsel aanwezige FABP worden gebonden en simultaan worden uitgestort.

Samenvattend kan, op grond van het in dit proefschrift beschreven onderzoek, het volgende worden gesteld:

1. FABP speelt een prominente rol bij de intracellulaire binding en het transport van vetzuren.

2. De uitstort van eiwitten uit beschadigd weefsel is een complex fenomeen waarbij uiteenlopende eigenschappen van deze eiwitten een rol spelen.

3. De functie van FABP als een mogelijke buffer voor een verhoogd vetzuurgehalte in hartspierweefsel dient nader onderzocht te worden. 


\section{PAPERS}

1. Vork MM, Glatz JFC, Surtel DAM, Van der Vusse GJ. 1990. Assay of the binding of fatty acids by proteins: evaluation of the Lipidex 1000 procedure. Mol Cell Biochem 98, 111-117.

2. Linssen MCJG, Vork MM, De Jong YF, Glatz JFC, Van der Vusse GJ. 1990. Fatty acid oxidation capacity and fatty acid-binding protein content of different cell types isolated from rat heart. Mol Cell Biochem 98, 19-25.

3. Vork MM, Glatz JFC, Surtel DAM, Knubben HJM, Van der Vusse GJ. 1991. A sandwich enzyme linked immuno sorbent assay for the determination of rat heart fatty acid-binding protein using the strepavidinbiotin system. Application to tissue and effluent samples from normoxic rat heart perfusion. Biochim Biophys Acta 1075, 199-205.

4. Van Nieuwenhoven FA, Vork MM, Surtel DAM, Kleine AH, Van der Vusse GJ, Glatz JFC. 1991. Highyield two-step chromatographic procedure for purification of fatty acid-binding protein from human heart. J Chromatography 570, 173-179.

5. Vork MM, Trigault N, Snoeckx LHEH, Glatz JFC, Van der Vusse GJ. 1992. Heterogeneous distribution of fatty acid-binding protein in the hearts of Wistar Kyoto and spontaneously hypertensive rats. J Mol Cell Cardiol 24, 317-321.

6. Van Breda E, Keizer HA, Vork MM, Surtel DAM, De Jong YF, Van der Vusse GJ, Glatz JFC. 1992. Modulation of fatty acid-binding protein content of rat heart and skeletal muscle by endurance training and testosterone treatment. Eur J Physiol (Pflügers Arch) 421, 274-279.

7. Vork MM, Glatz JFC, Van Der Vusse GJ. 1993. On the mechanism of long chain fatty acid transport in cardiomyocytes as facilitated by cytoplasmic fatty acid-binding protein. $J$ Theor Biol 160, 207-222.

8. Glatz JFC, Vork MM, Cistola DP, Van der Vusse GJ. 1993. Cytoplasmic fatty acid-binding protein: significance for intracellular transport of fatty acids and putative role in signal transduction pathways. Prostagland Leuk Essent Fatty Acids 48, 33-41.

9. Vork MM, Glatz JFC, Van der Vusse GJ. 1993. Release of fatty acid-binding protein and long chain fatty acids from isolated rat heart after ischemia and subsequent reperfusion. Mol Cell Biochem, in press.

10. Garnier A, Poizat C, Keriel C, Cuchet P, Vork MM, De Jong YF, Glatz JFC. 1993. Modulation of fatty acid-binding protein content of adult rat heart in response to chronic changes in plasma lipid levels. Mol Cell Biochem, in press.

11. Volders PGA, Vork MM, Glatz JFC, Smits JFM. 1993. Fatty acid-binding proteinuria diagnoses myocardial infarction in the rat. Mol Cell Biochem, in press.

12. Glatz JFC, Vork MM, Kleine AH, Van der Vusse GJ. 1993. Significance of fatty acid-binding protein for the ischemic heart. Mol Cell Biochem, in press.

13. Van der Horst DJ, Van Doorn JM, Passier PCCM, Vork MM, Glatz JFC. 1993. Role of fatty acid-binding protein in lipid metabolism of insect flight muscle. Mol Cell Biochem, in press.

\section{ABSTRACTS}

1. Vork MM, Glatz JFC, Van der Vusse GJ. 1991. Flow characteristics and protein release during normoxic and low-flow ischemic perfusion of isolated rat hearts. Eur J Physiol (Pflügers Arch) 418, R151.

2. Van Breda E, Keizer HA, Vork MM, Surtel DAM, Van der Vusse GJ, Glatz JFC. 1991. Both testosterone and estradiol increase the fatty acid-binding protein content in heart muscle fibres of female rats. Eur J Physiol (Pflügers Arch) 418, R145.

3. Vork MM, Glatz JFC, Surtel DAM, Van der Vusse GJ. 1991. Discrepancy between fatty acid-binding protein ( $\mathrm{H}-\mathrm{FABPC}$ ) and lactate dehydrogenase $(\mathrm{LDH})$ release from isolated perfused rat hearts during normoxia, low-flow ischemia and reperfusion. J Mol Cell Cardiol 23 (suppl V), s98.

4. Glatz JFC, Meyers J, Van Enckevort E, Vork MM, Van der Vusse GJ. 1991. Modulation of rat heart fatty acid-binding protein (FABP) content by type and amount of dietary fat. Faseb $\mathrm{J} \mathbf{5}, \mathrm{A} 1641$.

5. Vork MM, Glatz JFC, Van der Vusse GJ. 1991. Does fatty acid-binding protein facilitate the diffusion of oleic acid ? (letter). Biochem J 280, 835.

6. Van Breda E, Glatz JFC, Vork MM, Surtel DAM, Keizer HA, Van der Vusse GJ. 1991 Testosterone increases fatty acid-binding protein (FABP) content of soleus but not of EDL muscle of female rats. Faseb J 5, A1159.

7. Vork MM, Glatz JFC, Van der Vusse GJ. 1992. Fatty acid-binding protein (FABP) enhances the longchain fatty acid (FA) translocation in heart myocytes. Eur J Physiol (Pflügers Arch) 420, R108. 


\section{CURRICULUM VITAE}

$1961 \quad$ Geboren te Roermond op 17 januari

1973-1980 VWO, Bisschoppelijk College Schöndeln, Roermond.

1981-1985 Hoger laboratoriumonderwijs klinische chemie, Zuid-Limburgse Laboratoriumschool Sittard.

1985-1988 Research analist, vakgroep fysiologie, Rijksuniversiteit Limburg.

1989-1992 AlO opleiding, vakgroep fysiologie, Rijksuniversiteit Limburg.

1993-

Post-doc medewerker, vakgroep fysiologie, Rijksuniversiteit Limburg. 
